\title{
DETECÇÃO E CONTROLE DO OFF FLAVOR EM TILÁPIA DO NILO (Oreochromis niloticus), POR MEIO DE DEPURAÇÃO E DEFUMAÇÃO
}

\section{DENISE OLIVEIRA BIATO}

\author{
Dissertação apresentada à Escola Superior de \\ Agricultura "Luiz de Queiroz", Universidade de São \\ Paulo, para obtenção do título de Mestre em Ciências, \\ Área de Concentração: Ciência e Tecnologia de \\ Alimentos.
}

P I R A C I C A B A

Estado de São Paulo - Brasil

Janeiro - 2005 


\section{DETECÇÃO E CONTROLE DO OFF FLAVOR EM TILÁPIA DO NILO (Oreochromis niloticus), POR MEIO DE DEPURAÇÃO E DEFUMAÇÃO}

\section{DENISE OLIVEIRA BIATO}

Engenheiro Agrônomo

Orientador: Prof ${ }^{\mathrm{a}}$. Dr ${ }^{\mathrm{a}}$. MARÍLIA OETTERER

Dissertação apresentada à Escola Superior de Agricultura "Luiz de Queiroz", Universidade de São Paulo, para obtenção do título de Mestre em Ciências, Área de Concentração: Ciência e Tecnologia de Alimentos.

P I R A C I C A B A

Estado de São Paulo - Brasil

Janeiro - 2005 
Dados Internacionais de Catalogação na Publicação (CIP) DIVISÃO DE BIBLIOTECA E DOCUMENTAÇÃO - ESALQ/USP

Biato, Denise Oliveira

Detecção e controle do off flavor em tilápia do Nilo (Oreochromis niloticus), por meio de depuração e defumação / Denise Oliveira Biato. - - Piracicaba, 2005.

$105 \mathrm{p}$.

Dissertação (Mestrado) - - Escola Superior de Agricultura Luiz de Queiroz, 2005.

Bibliografia.

1. Análise de alimento 2. Cianobactéria 3. Defumação 4. Depuração 5. Microbiologia de alimento 6. Qualidade da água 7. Qualidade do alimento 8. Tanque 9. Tilápia-do-Nilo I. Títul

CDD 664.94 
A Deus que é digno, santo, fiel, amigo, maravilhoso

\section{OFEREÇO}

Aos meus pais, Fernando e Isabel Rosa, pela educação, incentivo, apoio e confiança durantes esses anos e ao meu namorado Daniel Leite pelo carinho e dedicação. 


\section{AGRADECIMENTOS}

A Deus, por todos os momentos de alegria e tristeza, por cuidar de mim, por ser o meu melhor amigo e por mais uma conquista.

Aos meus pais, pelo grande incentivo, apoio, consolo, dedicação e amizade.

Ao meu namorado por estar sempre ao meu lado, pelo carinho e dedicação.

Aos meus irmãos Felipe e Priscila pelo consolo nos momentos difíceis e pelo apoio.

Ao meu sobrinho Jonathas pelos momentos de alegria e distração.

À $\operatorname{Prof}^{\mathrm{a}} \operatorname{Dr}^{\mathrm{a}}$ Marília Oetterer, pela orientação, paciência e amizade, tornando possível a elaboração deste trabalho.

À CAPES, pela bolsa concedida.

A todos do laboratório de pescado, Ivani, Roberta e Juliana, pela ajuda na condução deste trabalho e pela amizade.

Aos professores Drs. José Eurico Possebon Cyrino, Marta Helena Filet Spoto, Solange Guidolin Canniatti Brazaca, Cláudio Rosa Galo, Elisabete Maria Macedo Viegas e Margarida Barros pelas sugestões e auxílio nas correções.

Ao $\operatorname{Prof}^{0} \operatorname{Dr}^{0}$ Cláudio Rosa Galo pela elaboração das análises microbiológicas.

Ao Eng. Agrônomo Marcelo Corrêa Alves, pela ajuda nas análises estatísticas.

Ao amigo, Eduardo Oliveira Salán, pela realização das análises microbiológicas.

Ao amigo, Jony Koji Daikiri pela ajuda na realização da despesca.

Ao Departamento de Zootecnia, em especial ao $\operatorname{Prof}^{0}$. $\operatorname{Dr}^{0}$. José Eurico Possebon Cyrino pela permissão do uso de tanques para depuração das tilápias. E aos funcionários, Sérgio e Júnior pelo auxílio no processo de depuração dos peixes. 
A bolsista de iniciação científica, Luciana Kimie Savay da Silva pela amizade e colaboração na realização deste trabalho.

À amiga, Lílian Marques Pino pela amizade durante todos esses anos.

As amigas Sula, Gisa e Ana Paula pela amizade e pelos maravilhosos momentos na presença de Deus.

As bibliotecárias Midiam Gustinelli e Beatriz Helena Giongo pelo auxílio técnico no decorrer do curso.

A todos os participantes da análise sensorial.

E a todas as pessoas que direta ou indiretamente colaboraram para a realização deste trabalho. 


\section{SUMÁRIO}

Página

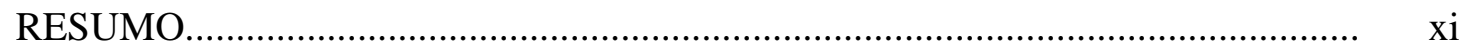

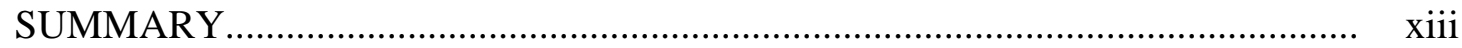

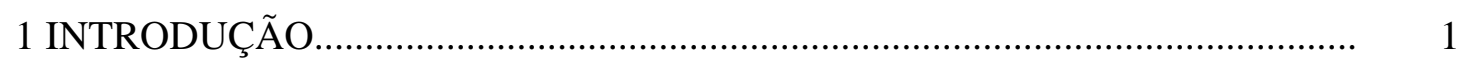

2 REVISÃO DE LITERATURA...................................................................... 3

2.1 Indicadores da qualidade da água para piscicultura............................................. 3

2.1.1 Cor aparente e turbidez................................................................................... 3

2.1.2 Sabor e odor.................................................................................................... 4

2.1.3 Oxigênio dissolvido e temperatura.................................................................. 5

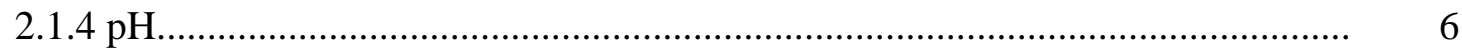

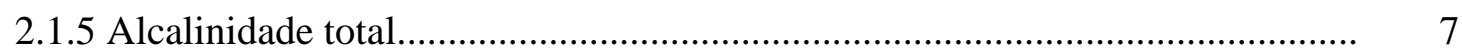

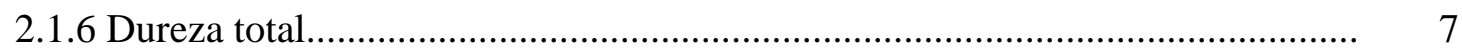

2.1.7 Amônia e nitrito........................................................................................... 8

2.2 Qualidade da água e suas influências na qualidade do sabor e odor do peixe...... 8

2.2.1 Fitoplâncton.................................................................................................... 8

2.2.2 Eutrofização............................................................................................ 10

2.2.3 Sabores e odores em pescado........................................................................... 11

2.2.4 Impacto econômico do off flavor no cultivo de organismos aquáticos.............. 14

2.2.5 Utilização de algicida para controle de algas.................................................... 15

2.3 A tilápia como matéria-prima.................................................................................. 15

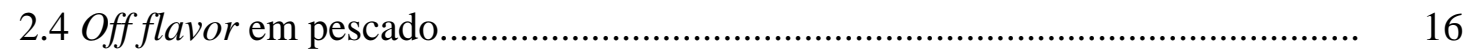

2.5 Depuração como medida de prevenção e controle do off flavor.......................... 18

2.6 Defumação como meio de mascarar o off flavor .................................................... 21 
2.7 Análise sensorial como meio de avaliar o off flavor.

3 INFLUÊNCIA DA QUALIDADE DA ÁGUA NO SABOR E ODOR DE PEIXES CULTIVADOS..................................................................................... 25

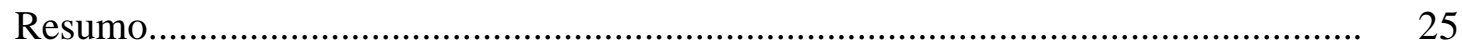

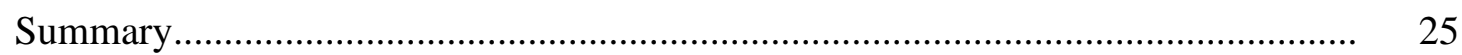

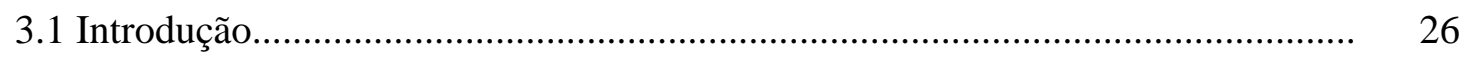

3.2 Material e Métodos.................................................................................. 28

3.2.1 Procedimento para coleta da água de cultivo e do tanque de depuração........... 28

3.2.2 Análises microbiológicas.................................................................................. 28

3.2.2.1 Coliformes totais e coliformes fecais.......................................................... 28

3.2.3 Análises físico-químicas.................................................................................... 29

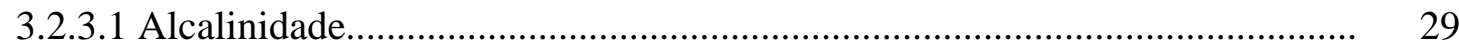

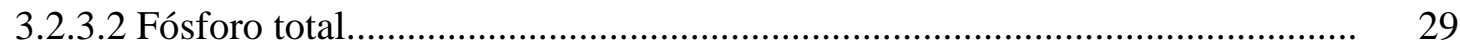

3.2.3.3 Nitrogênio amoniacal................................................................................... 29

3.2.3.4 Condutividade elétrica..................................................................................... 29

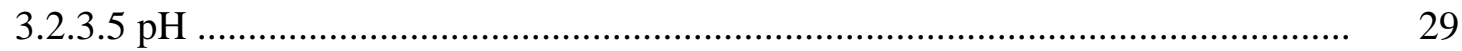

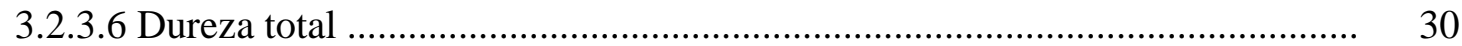

3.2.3.7 Oxigênio dissolvido .................................................................................... $\quad 30$

3.2.3.8 Transparência ........................................................................................... $\quad 30$

3.2.3.9 Temperatura...................................................................................... $\quad 30$

3.2.4 Determinação de geosmina.................................................................. $\quad 30$

3.2.5 Análises qualitativas e quantitativas de algas e cianobactérias......................... 30

3.3 Resultados e discussão.................................................................................. 31

3.3.1 Análises microbiológicas............................................................................. 31

3.3.1.1 Análise da água de cultivo...................................................................... 31

3.3.1.2 Análise da água de depuração...................................................................... 31

3.3.2.Análises Físico-químicas e de geosmina da água de cultivo e de depuração..... 32

3.3.2.1 Alcalinidade Total.......................................................................................... 32

3.3.2.2 Fósforo total........................................................................................ 32

3.3.2.3 Nitrogênio Amoniacal...................................................................................... 33 
3.3.2.4 Condutividade Elétrica......................................................................... 33

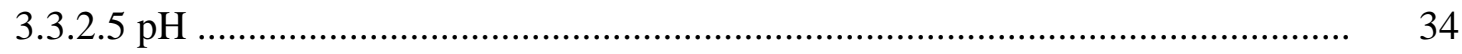

3.3.2.6 Dureza Total.......................................................................................... $\quad 35$

3.3.2.7 Oxigênio Dissolvido................................................................................. 35

3.3.2.8 Temperatura............................................................................................ 36

3.3.2.9 Transparência....................................................................................... 36

3.3.3 Determinação de geosmina........................................................................... 37

3.3.4 Análises qualitativas e quantitativas de algas e cianobactérias........................ 38

3.3.4.1 Água de cultivo e de depuração................................................................. 38

3.4 Conclusões.................................................................................................... 57

4 DETERMINAÇÃO DO OFF FLAVOR EM TILÁPIA DO NILO (Oreochromis niloticus) E O SEU CONTROLE ATRAVÉS DA DEPURAÇÃO........................... 58

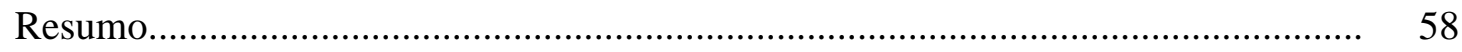

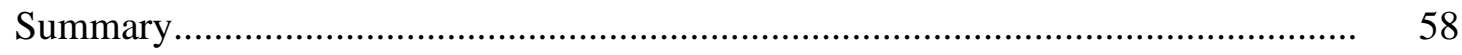

4.1 Introdução....................................................................................................... 59

4.2 Material e Métodos.......................................................................................... 60

4.2.1 Procedimento de depuração............................................................................. 60

4.2.2 Procedimento para coleta das amostras........................................................... $\quad 60$

4.2.3 Determinação da perda de peso..................................................................... 60

4.2.4 Preparo do pescado para análises e processamento.......................................... 61

4.2.5 Análises microbiológicas............................................................................ 61

4.2.5.1 Coliformes totais e coliformes fecais......................................................... 61

4.2.5.2 Salmonella spp........................................................................................ 62

4.2.5.3 Staphylococcus coagulase positiva........................................................... 62

4.2.5.4 Contagem total de mesófilos aeróbios........................................................... 63

4.2.6 Análises físico-químicas................................................................................... 63

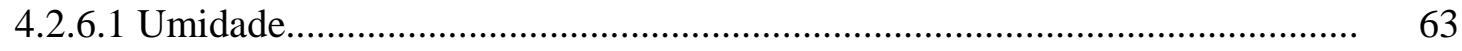

4.2.6.2. Proteína bruta................................................................................................. 63

4.2.6.3. Lipídeos...................................................................................................... 63

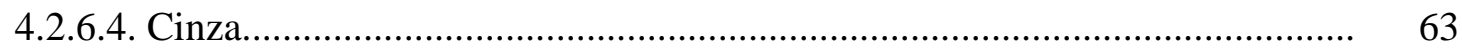


4.2.6.5 Nitrogênio não protéico (NNP).................................................................... 63

4.2.6.6 Bases nitrogenadas voláteis totais (BNVT)................................................. 63

4.2.6.7 Determinação de $\mathrm{pH}$.................................................................................... 64

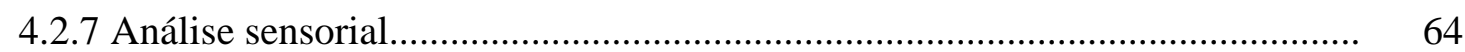

4.2.7.1 Seleção preliminar dos provadores............................................................... 64

4.2.7.2 Levantamento de atributos..................................................................... 64

4.2.7.3 Elaboração das fichas individuais................................................................. 64

4.2.7.4 Procedimento para análise sensorial............................................................ 65

4.2.8 Análise estatística............................................................................................. 65

4.3 Resultados e discussão................................................................................... 65

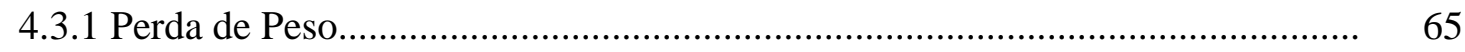

4.3.2 Análises microbiológicas............................................................................... 66

4.3.3 Análises Físico-Químicas.............................................................................. 67

4.3.3.1 Composição Centesimal............................................................................... 67

4.3.3.2 Nitrogênio não protéico - NNP...................................................................... $\quad 70$

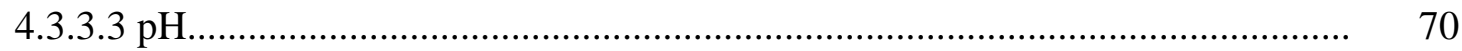

4.3.3.4 Bases nitrogenadas voláteis totais - BNVT ............................................... 71

4.3.4 Análise sensorial.................................................................................... 72

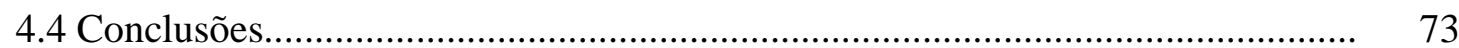

5 UTILIZAÇÃO DA DEFUMAÇÃO COMO MEIO DE MASCARAR O OFF FLAVOR EM TILÁPIA DO NILO (Oerochromis niloticus)................................... 74

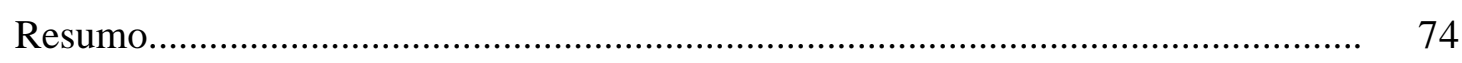

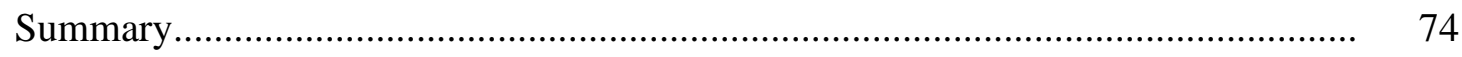

5.1 Introdução..................................................................................................... $\quad 75$

5.2 Material e Métodos......................................................................................... $\quad 76$

5.2.1 Processamento do pescado defumado............................................................... 76

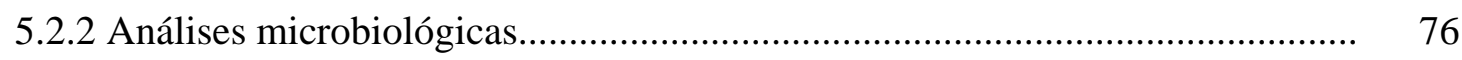

5.2.2.1 Coliformes totais e coliformes fecais............................................................. 76

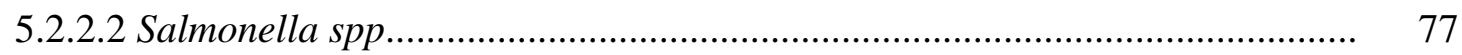

5.2.2.3 Staphylococcus coagulase positiva................................................................. 77 


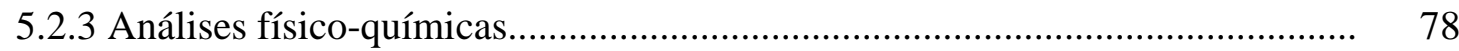

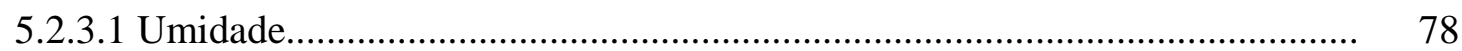

5.2.3.2 Proteína bruta............................................................................................. $\quad 78$

5.2.3.3 Lipídeos.............................................................................................. $\quad 78$

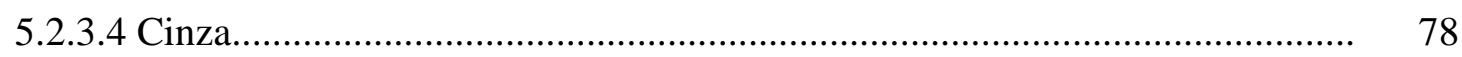

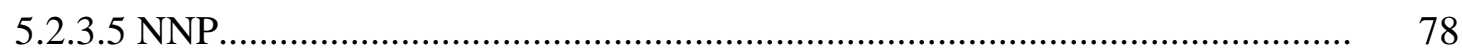

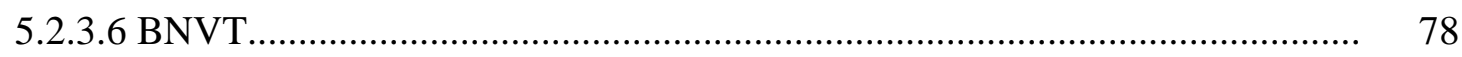

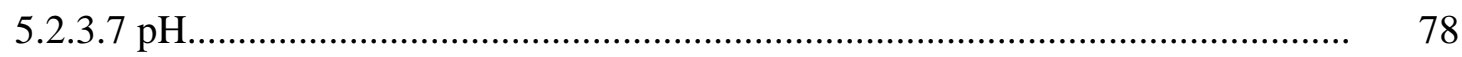

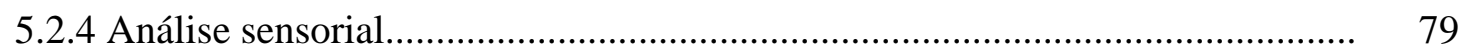

5.2.4.1 Seleção preliminar dos provadores.................................................................. 79

5.2.4.2 Levantamento de atributos............................................................................. $\quad 79$

5.2.4.3 Elaboração das fichas individuais.............................................................. 79

5.2.4.4 Procedimento para análise sensorial................................................................ $\quad 79$

5.2.5 Análise estatística.................................................................................... 80

5.3 Resultados e discussão.................................................................................... $\quad 80$

5.3.1 Análises microbiológicas........................................................................ 80

5.3.2 Análises Físico-Químicas.............................................................................. 81

5.3.2.1 Composição Centesimal.............................................................................. 81

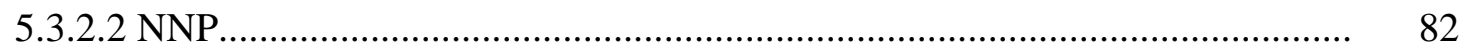

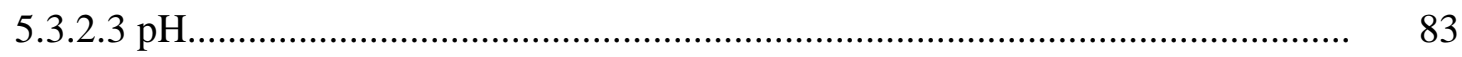

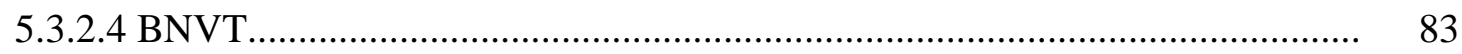

5.3.3 Análise sensorial................................................................................... 84

5.4 Conclusões............................................................................................... 85

6 CONCLUSÕES GERAIS.......................................................................... 86

REFERÊNCIAS BIBLIOGRÁFICAS............................................................. 87 


\title{
DETECÇÃO E CONTROLE DO OFF FLAVOR EM TILÁPIA DO NILO (Oreochromis niloticus), POR MEIO DE DEPURAÇÃO E DEFUMAÇÃO
}

\author{
Autora: DENISE OLIVEIRA BIATO \\ Orientador: Prof ${ }^{\mathrm{a}}$. Dr ${ }^{\mathrm{a}}$. MARÍLIA OETTERER
}

\section{RESUMO}

Atualmente, as perdas econômicas são uma realidade devido ao problema de off flavor em pescado, ocasionados pela qualidade da água dos criatórios e pelo manejo empregado no cultivo, nem sempre satisfatórios. Buscou-se a avaliação microbiológica, físico-química e sensorial dos peixes, com a finalidade de detectar prováveis alterações que estivessem comprometendo a qualidade do pescado. Com o objetivo de detectar e controlar o off flavor em tilápias cultivadas foi sugerido a depuração antes da distribuição e venda e a utilização da defumação como meio de mascarar este problema. O monitoramento da qualidade do pescado iniciou-se com as análises microbiológicas, físico-químicas e biológica da água dos tanques de cultivo e de depuração. Os peixes provenientes de área de cultivo do Estado de São Paulo, região de Artur Nogueira, da espécie tilápia do Nilo, Oreochromis niloticus, foram submetidos à depuração (3, 5 e 7 dias) e a seguir foram eviscerados e filetados. Os peixes submetidos à depuração e o controle foram comparados entre si para posterior escolha do melhor tempo para depuração; estes, não apresentaram diferenças significativas $(\mathrm{p}>0,05)$ para composição centesimal, nitrogênio não protéico - NNP, bases nitrogenadas voláteis totais - BNVT e pH nos tempos de depuração. O processo de depuração provocou perda de peso mais intensa nos três primeiros dias de depuração. Através das análises sensoriais verificou-se 
que os peixes, que corresponderam ao controle, apresentaram maior intensidade de off flavor quando comparados aos demais. A depuração por 3 dias para o atributo odor apresentou eficiência semelhante, estatisticamente (Teste F), ao tratamento por 5 dias porém, foi considerada diferente do tratamento por 7 dias. Para o atributo sabor os tratamentos de 3, 5 e 7 dias não diferiram, estatisticamente, entre si. A água do tanque de cultivo apresentou problemas de eutrofização e presença de geosmina, ao contrário da água do tanque de depuração que apresentou-se límpida e ausente de geosmina. Os peixes que não sofreram depuração (controle), foram submetidos à defumação. Os filés de peixe in natura e os defumados foram comparados entre si, quanto a composição centesimal e verificou-se que estes foram afetados significativamente (Teste F). Para o nitrogênio não protéico - NNP, as bases nitrogenadas voláteis totais - BNVT e o pH não houve alteração significativa $(\mathrm{p}>0,05)$ quanto aos tratamentos. Através das análises sensoriais verificou-se que os peixes in natura apresentaram maior intensidade de off flavor quando comparados aos defumados. Para os atributos odor e sabor houve diferença significativa $(\mathrm{p}>0,05)$ entre os tratamentos. O processo de depuração permitiu bons resultados quanto a eliminação de off flavor da tilápia, pois, através das análises realizadas, pode-se aferir o tempo ideal de 5 dias de depuração conduzida em um tanque com água corrente e limpa. Quando se comparou o pescado defumado com o pescado in natura, o primeiro recebeu uma maior aceitação pelos degustadores. O processo de defumação é uma forma de mascarar a presença do off flavor; é um processo simples, pouco oneroso e que pode ser adotado prontamente pelos produtores como forma de agregar valor ao pescado. 


\title{
OFF FLAVOR DETECTION AND CONTROL IN NILE TILAPIA (Oreochromis niloticus) THROUGH DEPURATION AND SMOKING
}

\author{
Author: DENISE OLIVEIRA BIATO \\ Adviser: Prof ${ }^{\mathrm{a}}$. Dr ${ }^{\mathrm{a}}$. MARÍLIA OETTERER
}

\section{SUMMARY}

Currently, economic losses are a reality due to the fish off flavor provoked by the handling used in the culture and by the water quality of the fish tanks, which are not always satisfactory. Microbiological, physical-chemical and sensory evaluations of the fish were carried out in order to detect probable alterations that would compromise the fish quality. The off flavor detection, as well as, the suggestion for depuration before distribution and sale, and the use of the smoking as a way of disguising this problem were the objectives of this research. Microbiological, physical-chemical and biological analyses of the waters in the fish and the depuration ponds were performed to monitor the quality of the fish. The fish-Nile Tilapias (Oreochromis niloticus) from the area of Arthur Nogueira, in the State of São Paulo - was submitted to the depuration (3, 5 and 7 days). The fish submitted to the depuration and the control fish were compared in order to find the best depuration period. No significant differences $(p>0.05)$ for centesimal composition, non-protein nitrogen - NNP, total base volatile nitrogen BNVT, and $\mathrm{pH}$ were found among the depuration periods. The depuration process provoked a more intense weight loss in the first three days for depuration. Through the sensory analyses, 
we could verify that the control fish presented a greater off flavor intensity than the others. The three-day depuration showed a similar statistical efficiency (F Test) than that of the five-day treatment, but differed from that of the 7-day treatment. As for the flavor attribute, the 3, 5, and 7-day treatments did not show a significant difference, statistically. The water in the fish pond presented eutrophization problems and presence of geosmine, whereas the water in the depuration pond was clear and geosmine-free. The fish that did not go through depuration (control) were submitted to smoking. Fresh fish fillets were compared to the smoked ones. As to the centesimal composition, we verified that they were significantly affected (F Test). As to non-protein nitrogen - NNP, total base volatile nitrogen - BNVT and $\mathrm{pH}$, there were no significant changes ( $\mathrm{p}>0.05)$ either among the treatments. Through sensory analysis, we verified that the fresh fish presented a more intense off flavor than the smoked ones. As to odor and flavor, there was a significant ( $>0.05$ ) difference among the treatments. The depuration process was efficient in the elimination of the off-flavor in the tilapia, for, according to our analyses, we could conclude that the ideal period for this elimination was 5 days of depuration, carried out in a pond with clean running water. When compared to the fresh fish, the smoked fish was better accepted by the panelists. The smoking process is a way of disguising the off flavor; it is a simple, inexpensive process, which can be readily adopted by producers a way of adding value to the fish. 


\section{INTRODUÇÃO}

Para atender a demanda de um mercado consumidor exigente, os produtores vêm se organizando para oferecerem produtos com padrões de qualidade mais rigorosos quanto ao tamanho, sabor, cor e textura do pescado. Dentro do processo de produção, a qualidade da água é condição imprescindível para a obtenção de pescado que atenda a essas exigências.

A água se em condições inadequadas, em relação aos parâmetros de qualidade, além de prejudicar o crescimento, reprodução, saúde e sobrevivência do pescado, pode interferir nas características organolépticas, favorecendo o surgimento de sabores ou odores indesejáveis que acabam por comprometer a aceitação do pescado e a conseqüente comercialização. Parâmetros físicos, químicos e biológicos determinam a qualidade da água nos viveiros de cultivo (Kubitza, 2003).

O ambiente límnico vem sofrendo ao longo do tempo profundas alterações que trazem como conseqüência o comprometimento da qualidade da água utilizada para consumo humano, atividade industrial e manutenção da vida aquática (Beyruth, 1996). Atualmente, a qualidade das águas em muitas regiões do mundo revela o descaso com que foram tratadas as descargas industriais, urbanas e da agricultura nas atividades humanas, assim como a má utilização e planejamento inadequado do recurso.

A Geosmina (GEO) e o 2-metilisoborneol (MIB) são compostos orgânicos que conferem gostos e odores extremamente desagradáveis à água, deixam a água com forte "gosto de barro" e "cheiro de inseticida". A presença desses compostos orgânicos deve-se a proliferação de algas em mananciais com altos níveis de nutrientes, e é ampliada por fatores associados à luz, poluição, calor e chuvas. Totalmente complexos 
e prejudiciais à saúde quando em excesso, estes compostos necessitam de uma tecnologia diferenciada de filtração/absorção (Jornal consumidorsa on line, 2001).

A ocorrência de odor e sabor indesejáveis em peixes foi apontada por Iredale (1974) no Encontro Técnico da FAO realizado em 1972, como sendo conseqüência da degradação do meio ambiente, devido à descarga de detritos industriais e domésticos nos cursos de água. Para o autor, o odor desagradável presente nos peixes habitantes dos Grandes Lagos dos Estados Unidos era, provavelmente, originário de certos tipos de fungos actinomicetos e algas azuis presentes, normalmente, em águas doces.

Segundo Kubitza (2000), paro o Catfish nos Estados Unidos, os prejuízos anuais causados pelo off flavor são estimados em US\$ 50 milhões. O cálculo destes prejuízos considera o atraso no cronograma de despesca, a redução no crescimento e na eficiência alimentar, e o aumento na mortalidade decorrentes de problemas de qualidade da água e doenças ocorridas em função da retenção dos peixes nos viveiros até a dissolução da condição de off flavor.

A relação entre qualidade de água e ocorrência de off flavor do tipo "terra” e "mofo", é evidenciada em muitos estudos. Em geral, condições limnológicas específicas permitem o surgimento de espécies variadas de actinomicetos e cianobactérias sintetizadoras de (MIB) e (GEO), compostos capazes de alterar negativamente o sabor e o odor de filés de peixes que passam a apresentar sabores descritos como "terra” ou "mofo" (Ploeg, 1992; Persson, 1995; Johnsen et al., 1996; Schrader et al., 1998; Miller et al., 1999; Tucker \& Ploeg, 1999).

Yamprayoon \& Noomhorm (2000) comprovaram que a defumação mascarou o sabor e odor de “terra” e "mofo” em filés de tilápia do Nilo (Oreochromis niloticus).

O mercado nacional para defumados ainda é considerado restrito, não havendo produção em escala industrial que possa vir competir com os produtos importados, por outro lado, este produto é obtido em escala artesanal. A importação brasileira de pescado defumado, em 1995, foi de 297t, e em 1997 foi de 401t (Soccol, 2002). 


\section{REVISÃO DE LITERATURA}

\subsection{Indicadores da qualidade da água para piscicultura}

\subsubsection{Cor aparente e turbidez}

Turbidez representa a medida da transparência de uma amostra ou corpo d’água, em termos da redução de penetração da luz, devido à presença de matéria em suspensão ou substâncias coloidais, orgânicas ou inorgânicas. Em outras palavras, é a medida da transparência de uma amostra ou corpo d'água, em termos da redução de penetração da luz, devido à presença de matéria em suspensão ou substâncias coloidais (Lacerda, 2003).

Turbidez e cor são responsáveis, ainda, por uma variação qualitativa da luz no interior da massa d’água. Com efeito, mesmo a água pura absorve muito mais radiações da parte vermelha-alaranjada do espectro que as variações verdes-azuladas. Além disso, os coeficientes de absorção, nas águas naturais, variam de acordo com as substâncias nela dissolvidas ou em suspensão. De qualquer maneira, os raios luminosos de pequeno comprimento de onda, sendo dotados de maior poder de penetração, são os que atingem as maiores profundidades. Assim sendo, os vegetais de grandes profundidades, recebem uma luz muito mais rica em raios verde-azulados que os habitantes das zonas próximas à superfície (Branco, 1986).

A transparência da água pode ser um indicativo da densidade planctônica e da ocorrência de níveis críticos de oxigênio durante o período noturno (Kubitza, 2003).

Em alguns casos a água pode ser amarela, marrom, negra ou transparente, dependendo do tipo e quantidade de plâncton presente. A água transparente geralmente 
é encontrada em viveiros com pouca matéria orgânica ou com uma grande quantidade de zooplâncton (animais microscópicos). Outros componentes contribuem com a cor e a turbidez de viveiros, como material morto particulado (detritos), bactérias, partículas de solo em suspensão e substancias húmicas dissolvidas. Em viveiros, o plâncton deve ser a principal fonte de turbidez (Boyd, 1997).

\subsubsection{Sabor e odor}

A água possui seu sabor característico, que se deve à presença de sais e gases nela dissolvidos, sendo classificada, porém, “sem gosto”, pela comparação com outros sabores. Assim, qualquer sabor (ou odor) diferente daquele característico de água "sem gosto” é considerado como objetável. Há várias substâncias que podem produzir gosto ou odor objetáveis na água mesmo em concentrações muito abaixo daquelas que poderiam causar algum prejuízo à saúde. Pode-se citar, como exemplo, as substâncias produzidas por certos tipos de algas, que vivem e se reproduzem em represas e lagos. Essas substâncias transmitem à água odor e gosto, que podem lembrar mofo e terra, entre outros, dependendo do tipo de alga presente (Pelczar, 1997).

De um modo geral, a presença de odor e sabor em águas pode ser ocasionada pelos seguintes motivos (American Water Works Association Research FoudationAWWA, 1987; Ferreira Filho, 1996):

- Presença de constituintes inorgânicos em concentrações elevadas tais como o ferro, cloreto, sulfato, gás sulfídrico, entre outros;

- Presença de compostos orgânicos originários a partir de fontes antropogênicas (fenóis, nitrofenóis) e demais compostos aromáticos (tetracloreto de carbono, tetracloroetileno);

- Presença de compostos originários a partir de fontes biogênicas. É sabido que inúmeros microrganismos, notadamente certas algas, especialmente as cianofíceas (algas azuis), bem como os actinomicetos são responsáveis pela produção de certos compostos orgânicos, resultantes do seu metabolismo, que, sob certas condições ainda não totalmente conhecidas, são liberados para a fase líquida. Estes compostos orgânicos 
são responsáveis por inúmeros problemas de odor e sabor em águas sendo, indubitavelmente, os mais difíceis de serem removidos.

Em 1995, uma pesquisa conduzida pela AWWA junto às companhias de Saneamento com o intuito de avaliar a dimensão dos problemas de gosto e odor em águas de abastecimento nos Estados Unidos da América concluiu que, a maioria dos casos relatados estavam relacionados com a presença de compostos orgânicos produzidos por algas e demais microrganismos no manancial; devido ao agente desinfetante empregado e a problemas decorrentes do sistema de distribuição de água.

\subsubsection{Oxigênio dissolvido e temperatura}

A água possui, naturalmente, oxigênio dissolvido em quantidade variável. A medida do oxigênio dissolvido na água é uma das maneiras mais comumente empregadas, para se obter informações a respeito das trocas biológicas e bioquímicas da água. O oxigênio encontrado na água é proveniente da atmosfera ou da fotossíntese de plantas aquáticas, e é utilizado por muitos processos bioquímicos respiratórios, bem como nas reações inorgânicas de mineralização. O oxigênio dissolvido é requerido para a respiração dos microorganismos aeróbios e de todas as outras formas de vida aeróbias. O oxigênio é fracamente dissolvido em água. A quantidade de oxigênio dissolvido depende da solubilidade do gás, pressão parcial do gás na atmosfera, temperatura, grau de pureza (salinidade, sólidos em suspensão) da água e das concentrações de vários íons. Como as reações bioquímicas que utilizam o oxigênio aumentam com o aumento da temperatura, os níveis de oxigênio dissolvido tendem a ser mais críticos no verão (Branco, 1986; Souza, 1986; Zeitouni, 2004).

Os processos oxidativos podem causar forte depressão de oxigênio, microrganismos animais e ou vegetais heterótrofos, quando proliferam em grande número, podem reduzir o oxigênio dissolvido a quase zero. A proliferação depende da matéria orgânica presente no manancial, portanto a entrada de matéria reduz o oxigênio, a demanda é respiratória, pois a oxidação é realizada por via enzimática, tratando-se, pois de uma demanda bioquímica de oxigênio, ou DBO. Aumenta também a concentração de gás carbônico, diminui o pH e dissolução dos carbonatos. Em águas 
ricas em materiais subaquáticos, à noite, os organismos somente respiram, reduzindo oxigênio e diminuindo o pH e, durante o dia, com a fotossíntese, produzem oxigênio, consumindo gás carbônico e aumentando o pH (Branco, 1986; Lembo, 2004; Portugal Filho, 2004; Souza, 1986).

A concentração de oxigênio dissolvido, entre outros fatores, assegura o adequado desenvolvimento e a sobrevivência de peixes. Fontes de águas superficiais desprovidas de oxigênio são resultantes de algum tipo de poluição (orgânica ou química), podendo conter outros compostos perigosos aos organismos aquáticos. A solubilidade do oxigênio na água varia de acordo com a temperatura, a salinidade e a pressão atmosférica do local (Kubitza, 2003).

A fotossíntese realizada pelo fitoplâncton é a principal fonte de oxigênio dissolvido na maioria dos viveiros de aqüicultura. No período diurno, o fitoplâncton remove o gás carbônico da água e produz oxigênio; no período noturno, não há fotossíntese, ocorrendo somente a remoção do oxigênio da água e a liberação de gás carbônico, pela respiração (Boyd, 1990).

A exigência quanto à temperatura da água de cultivo varia conforme a espécie do pescado e a fase de desenvolvimento em que este se encontra (ovo, larva, pós-larva ou juvenil) (Kubtiza, 2003).

\subsection{4 pH}

O pH é um importante indicador da estabilidade química da água; acima de 7 representa meio básico, e abaixo, meio ácido. $\mathrm{O}$ pH 7 indica a neutralidade do meio. $\mathrm{O}$ pH interfere e influencia as reações físico-químicas e bioquímicas na água, em termos de velocidade de reação e viabilidade dos mesmos (Lacerda, 2003).

A elevação do pH aumenta a concentração da fração tóxica da amônia na água. Valores baixos de $\mathrm{pH}$ aumentam a proporção das formas tóxicas do nitrito $\left(\mathrm{HNO}_{2}\right)$ e do gás sufídrico $\left(\mathrm{H}_{2} \mathrm{~S}\right)$, compostos tóxicos aos peixes (Kubitza, 2003). 


\subsubsection{Alcalinidade total}

É uma medição da capacidade da água de neutralizar os ácidos fortes. Os principais constituintes da alcalinidade são os bicarbonatos $\left(\mathrm{HCO}_{3}{ }^{-}\right)$, carbonatos $\left(\mathrm{CO}_{3}{ }^{-}\right)$ e os hidróxidos $\left(\mathrm{OH}^{-}\right)$. A distribuição entre as três formas na água é função do $\mathrm{pH}$, predominando sobremaneira o primeiro na faixa de $\mathrm{pH}$ de 6 a 9, a mais representativa da água. Este parâmetro não tem significado sanitário para a água potável, mas em elevadas concentrações confere um gosto amargo (Pádua, 1994).

A alcalinidade total é a concentração total de bases tituláveis na água, que no caso dos viveiros de aqüicultura, são o bicarbonato e o carbonato. A alcalinidade total está diretamente ligada à capacidade da água em manter seu equilíbrio ácido-básico (poder tampão da água), disponibilizando reservas de dióxido de carbono para plantas e impedindo mudanças bruscas no pH da água (Boyd, 1997).

\subsubsection{Dureza total}

A dureza da água se refere à concentração de cátions multimetálicos em solução. Os cátions mais freqüentemente associados à dureza são os cátions $\mathrm{Ca}^{+2} \mathrm{e}$ $\mathrm{Mg}^{+2}$ (Pelczar, 1997).

Os valores de dureza total e alcalinidade total, geralmente se equivalem, estando os íons $\mathrm{Ca}^{2+}$ e $\mathrm{Mg}^{2+}$, associados aos íons bicarbonatos e carbonatos. Em águas com alta alcalinidade e baixa dureza parte dos íons bicarbonato e carbonato associam-se

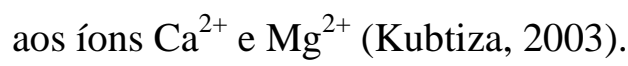

A dureza da água é composta por duas frações, a fração instável e a fração estável (Pádua, 1994):

- A fração instável quanto a dureza da água está relacionada com a baixa solubilidade dos sais carbonatos ( $\mathrm{Ca}, \mathrm{Mg}, \mathrm{Na}$ ) na formação e presença dos bicarbonatos solúveis, esses últimos dependentes dos aspectos físicos da água, (volume, calor) ou da ação de substâncias alcalinas para formarem carbonatos insolúveis que se precipitam e decantam. Esta fração apresenta, portanto, valores temporais, apontando momentaneamente a capacidade de se formar e encontrar teores maiores ou menores dos bicarbonatos e dos possíveis teores presentes e a serem novamente formados de 
carbonatos e hidróxidos. Tal situação indica também o potencial de estabilidade do $\mathrm{pH}$ na amostra d'água, relacionado à concentração de bicarbonatos presentes, portanto da capacidade de tamponamento do meio aquático

- Com os possíveis cloretos ou sulfatos $\left(\mathrm{CaCl}_{2} / \mathrm{MgCl}_{2}\right.$ e $\left.\mathrm{CaSO}_{4} / \mathrm{MgSO}_{4}\right)$ presentes em solução, tem-se a chamada dureza permanente, representando a fração, relativamente estável, desses sais altamente solúveis contidos na amostra. Não depende de outras situações físicas do sistema, como o calor, mas somente é influenciada pelas substâncias alcalinas possivelmente formados e presentes, como carbonato de sódio $\left(\mathrm{Na}_{2} \mathrm{CO}_{3}\right)$, hidróxido de cálcio $\left(\mathrm{Ca}(\mathrm{OH})_{2}\right)$ e hidróxido de sódio $(\mathrm{NaOH})$.

\subsubsection{Amônia e nitrito}

A amônia $\left(\mathrm{NH}_{3}\right)$ é um metabólico proveniente da excreção nitrogenada dos peixes e da decomposição microbiana de resíduos orgânicos. O nitrito $\left(\mathrm{NO}_{2}^{-}\right)$é um metabólico intermediário do processo de nitrificação, durante o qual a amônia é oxidada a nitrito $\left(\mathrm{NO}_{3}\right)$, através da ação de bactérias Nitrosomomas e Nitrobacter (Kubitza, 2003).

A matéria orgânica acumulada no tanque, resultante de restos de ração, dejetos dos peixes e algas mortas, começa a ser decomposta por ação de bactérias e fungos presentes na água, formando a amônia $\left(\mathrm{NH}_{3} / \mathrm{NH}_{4}{ }^{+}\right)$, composto tóxico para os peixes. A decomposição continua, onde a amônia, por ação das bactérias do gênero Nitrosomonas, é oxidada a nitrito $\left(\mathrm{NO}_{2}{ }^{-}\right)$, também tóxico. Seguindo o ciclo, as bactérias do gênero Nitrobacter oxidam o nitrito a nitrato $\left(\mathrm{NO}_{3}\right)$, relativamente bem menos tóxico que seus precursores e que é utilizado como nutriente por algas e plantas, fechando o ciclo (Pádua, 1994).

\subsection{Qualidade da água e suas influências na qualidade do sabor e odor do peixe}

\subsubsection{Fitoplâncton}

O plâncton é composto por organismos animais (zooplâncton) e organismos vegetais (fitoplâncton). O fitoplâncton é formado por algas unicelulares, em geral 
microscópicas, que conferem uma coloração esverdeada à água dos tanques e viveiros. São exemplos de organismos que compõem o fitoplâncton, as algas verdes, as diatomáceas e as cianofíceas (Branco, 1986).

As cianofíceas, cianobactérias ou algas azuis como são popularmente designadas, são fundamentalmente organismos fotossintéticos que compõem o fitoplâncton de águas doces, salgadas ou salobras, podendo também ser encontradas no solo e em rochas. Pertencem à classe taxonômica Cyanophyceae, ocorrendo, preferencialmente, em ambientes aquáticos muito eutrofizados e com pouca ou nenhuma movimentação de correntes (lagoas, reservatórios de água ou viveiros de aqüicultura). Desenvolvem-se mais intensamente em água doce, rica em nutrientes como fósforo e potássio, $\mathrm{pH}$ entre 5,0 a 9,0, temperatura acima de $15^{\circ} \mathrm{C}$ e oxigênio dissolvido elevado (acima de 7,0 mg de $\mathrm{O}_{2} / \mathrm{L}$ ). Podem ainda ocorrer em águas correntes desde que haja condições favoráveis para o seu desenvolvimento. Possuem dimensões muito reduzidas (2 a $50 \mu \mathrm{m}$ ) e vivem em forma de colônias ou filamentos. Não apresentam núcleo celular e seus pigmentos (ficocianina ou pigmentos azuis) associados à clorofila atuam na fotossíntese. São encontradas geralmente nas cores verde (predomínio de clorofila), amarela, avermelhada ou parda e seu aspecto assemelha-se a uma película de espessura variada flutuando na superfície da água. Sua reprodução é assexuada, ocorrendo através da divisão de esporos. Quando envelhecem ou morrem tornam-se menos densas, liberando na superfície da água, uma substância oleosa com odor característico (Branco, 1986).

Podem ocasionar níveis críticos de oxigênio em tanques de aqüicultura (principalmente no período noturno) devido ao desequilíbrio entre os mecanismos de fotossíntese e respiração, característico em sistemas ricos em matéria orgânica, que demandam grandes quantidades de oxigênio dissolvido. Mudanças bruscas no pH da água também ocorrem nessas condições, em conseqüência dos processos de respiração e fotossíntese, ocasionando níveis reduzidos de pH no período da manhã e níveis extremamente elevados no final da tarde, que podem causar a mortalidade de peixes (Branco, 1986). 
Algumas espécies produzem toxinas, que ao serem liberadas na água podem provocar intoxicações em seres humanos, peixes e outros animais domésticos. Os peixes cultivados em viveiros onde há o predomínio de cianofíceas, quando não depurados antes do abate, podem apresentar alterações organolépticas significativas e determinantes para a sua rejeição por parte dos consumidores, causando graves prejuízos ao aqüicultor (Branco, 1986).

\subsubsection{Eutrofização}

A eutrofização é o processo de enriquecimento das massas de água em nutrientes, tendo como conseqüência o crescimento excessivo de algas e plantas aquáticas. Na aqüicultura, a eutrofização pode ocorrer pelo excesso de adubação ou elevado arraçoamento e aporte de fezes e excretas nitrogenadas em sistemas com alta densidade de estocagem (Pereira, 2003).

Para a piscicultura, a adubação de tanques e viveiros é uma prática corriqueira e essencial para aumentar a biomassa planctônica (alimento natural) e, conseqüentemente, a produção de alguns peixes de grande importância econômica como a tilápia (Oreochromis sp). O alimento natural produzido através desse processo é de alto valor nutritivo, podendo contribuir com o suprimento de proteína, energia, vitaminas e minerais, reduzindo os custos com a alimentação. A presença de cianofíceas pode prejudicar os programas de adubação de viveiros. Essas algas não são aproveitadas eficientemente pelos peixes, competem por nutrientes e podem reduzir a entrada de luz na água, prejudicando o desenvolvimento do fitoplâncton realmente benéfico ao cultivo. Geralmente, a adubação é interrompida ao longo do cultivo em sistemas que utilizam ração completa (que proporciona adequado crescimento, reprodução e saúde aos organismos aquáticos), pois as próprias fezes e a excreção nitrogenada dos peixes são fontes de nutrientes para a manutenção do plâncton e outros organismos (Kubitza, 2000).

O excesso de material orgânico nos viveiros acelera a degradação da qualidade de água, levando a eutrofização, podendo prejudicar o crescimento e sobrevivência dos peixes devido à incidência de baixos níveis de oxigênio dissolvido na água, mudanças 
bruscas de $\mathrm{pH}$ e à proliferação de parasitas e patógenos. As algas cianofíceas são organismos que agem como indicadores de um estado de eutrofização avançado, possuindo capacidades competitivas que as tornam dominantes nestas situações, merecendo, portanto, a devida atenção dos piscicultores. É particularmente preocupante a freqüente ocorrência de "blooms" ou florescências de algas em que predominem as cianofíceas dos gêneros Microcystis, Anabaena, Aphanizomenom ou Oscillatoria. Isto ocorre quando as populações que se desenvolvem nas camadas subsuperficiais, repentinamente se deslocam para a superfície da água. Esse fenômeno pode ser observado com maior freqüência no verão, quando a temperatura da água é mais elevada e a luminosidade é intensa e prolongada. Estas florescências conferem à água uma cor verde intensa, diminuindo a sua transparência (Pereira, 2003).

A presença em larga escala de algas em corpos d’água com elevado grau de eutrofização podem causar problemas de gosto e odor através de dois mecanismos distintos, a saber: o primeiro mecanismo está diretamente relacionado com a morte das algas e subseqüente liberação para a fase líquida de compostos metabólicos, dentre estes o 2-metilisoborneol (MIB) e Geosmina (GEO). O segundo mecanismo está relacionado com a degradação do material celular morto, que pode servir como substrato para outros microrganismos, notadamente os actinomicetos e estes, produzindo diretamente os compostos causadores de gosto e odor (Ferreira Filho, 2001).

\subsubsection{Sabor e odor em pescado}

As algas constituem um dos mais importantes fatores de presença de sabor e odor nas águas. Várias pesquisas têm sido desenvolvidas, no sentido de identificar as substâncias presentes nas algas e que são responsáveis pelo seu cheiro e sabor característicos. A extração e destilação desse material levaram à conclusão de que são os ácidos graxos, presentes nas células, os principais causadores desse fenômeno. Os lipídeos totais da alga, quando extraídos, apresentam forte odor complexo, resultante dos odores dos vários ácidos graxos que entram em sua composição. A quantidade de lipídeos, nas células, aumenta com o seu envelhecimento, ao mesmo tempo em que 
diminui a quantidade de compostos nitrogenados, de maneira que as algas mais velhas tendem a apresentar sabor e odor mais pronunciados (Branco, 1986).

Os compostos MIB e GEO, principais causadores de odor e sabor indesejáveis na água, são produzidos e liberados para a fase líquida por actinomicetos e cianobactérias. Os actinomicetos são classificados como bactérias filamentosas e são encontrados em uma variedade de habitats, incluindo a água e sedimentos de rios e lagos. A sua ocorrência em águas naturais está diretamente relacionada ao escoamento superficial direto, que o carreia juntamente com os sedimentos da bacia hidrográfica para o corpo d’água (Ferreira Filho, 2001). Ainda que os actinomicetos possam ser encontrados em grande número em sedimentos de rios e lagos, alguns pesquisadores têm considerado que a sua atividade é extremamente limitada em ambientes anóxicos e anaeróbios (Silvey et.al, 1950; Morris et al, 1963). No entanto, quando em ambientes aeróbios, estes apresentam uma significativa capacidade de produção de MIB e GEO, o que, em parte, explica o fato de que quando mananciais submetidos a severas estiagens apresentam graves problemas de gosto e odor. Tal ocorrência é justificada pela exposição de parte do sedimento do fundo com a atmosfera, o que propicia uma condição aeróbia e conseqüente produção de sub-produtos metabólicos, dentre os quais os compostos MIB e GEO (Romano et al., 1963).

Do ponto de vista microbiológico, o ciclo de vida dos actinomicetos é dividido em dois estágios, sendo um anaeróbio e outro aeróbio e, é exatamente neste último que ocorre a produção e liberação de MIB e GEO para a fase líquida.

As cianobactérias durante o seu ciclo de vida produzem inúmeros compostos voláteis e não voláteis que, não podendo ser utilizados imediatamente ou armazenados para uso futuro, são liberados para a fase líquida. Do ponto de vista microbiológico, as cianobactérias ou algas azuis são microorganismos unicelulares procariontes e, deste modo, podem ser considerados como bactérias, no entanto, por serem fotossintetizantes também são consideradas como algas (Atlas et al., 1987). A variedade de compostos extracelulares liberados pelas cianobactérias é significativamente grande e, dentre estes, alguns podem causar problemas de gosto e odor diretamente e indiretamente, além de apresentarem toxicidade aguda e crônica (Repavich et al, 1990). 
O off flavor caracteriza-se pela presença de diferentes aromas nos peixes designados popularmente como o de "algas” (por associação), “peixe”, "barro”, “gerânio”, “violeta”, “inseticida BHC”, “remédio”, “formol”, “mofo”, “esgoto” e outros. Embora não tendo efeitos negativos em termos de saúde pública, essas alterações no pescado diminuem a aceitação do mesmo para o consumo. As fontes de tais características são os lipídios totais e ácidos voláteis (gases) produzidos e acumulados durante a vida das células, associadas ou não a outras substâncias e liberados quando da sua destruição por ruptura espontânea, ou provocada, devido à decomposição pela ação de fungos ou bactérias. Portanto, a intensidade desses odores e sabores depende do tempo, do ciclo de vida das algas e do meio em que estejam (Pádua, 1994).

A ocorrência de sabor ou odor indesejados em peixes é freqüentemente detectada em viveiros, com altos níveis de arraçoamento, onde o grande aporte de nutrientes favorece o desenvolvimento de algas cianofíceas e fungos actinomicetos. Segundo Kubitza (2000), tilápias cultivadas em tanques-rede e “raceways” também podem apresentar mau sabor, sendo, no entanto, menos freqüente a incidência desse problema nesses sistemas de cultivo, devido à utilização de água de reservatórios oligotróficos.

Armstrong et al. (1986), estudaram os fatores ambientais que poderiam afetar o sabor do catfish (Ictalurus punctatus) em tanques de produção da região do Alabama (EUA) e verificaram que o sabor do barro havia sido mais severo no final do verão quando a atividade algal e microbial nos viveiros foi mais alta, em resposta ao elevado fornecimento de alimento. Brown \& Boyd (1982) constataram a relação entre off flavor e taxas de arraçoamento na região do oeste central do Alabama, já que as taxas de alimento inserido nos viveiros de criação de catfish (Ictalurus punctatus) por eles estudados vinham aumentando ao longo dos anos que antecederam o estudo, favorecendo o crescimento de algas e actinomicetos.

A busca dos produtores pelo melhor desempenho produtivo de seus peixes, visando uma produção altamente lucrativa, tem acentuado o problema da eutrofização das águas utilizadas nos cultivos. Já existe consenso de que a qualidade da água 
interfere na qualidade do sabor do pescado, mas por outro lado ainda desconhece-se exatamente de que forma isto ocorre. Este conhecimento é muito importante para a tomada de medidas preventivas, tanto econômicas, quanto na manutenção racional da água utilizada por parte dos aquicultores (Lima, 2001).

\subsubsection{Impacto econômico do off flavor no cultivo de organismos aquáticos}

A eutrofização das águas cultivadas traz problemas sócios -econômicos cada vez mais preocupantes e evidentes, sobretudo nos países em desenvolvimento, onde em geral não existe uma legislação específica e os próprios aquicultores não estão sensibilizados pelos problemas gerados nesta esfera da atividade aqüícola. Especificamente, o problema crescente da ocorrência de off flavor em peixes cultivados pode ser mais um fator limitante para o desenvolvimento da aqüicultura mundial. Segundo Boyd (1998) todo o empreendimento aqüícola pode ser inviabilizado em função da baixa qualidade da água para o abastecimento do cultivo e a ocorrência de determinados tipos de off flavor relacionados a eutrofização.

O cultivo de peixes de água doce é um dos setores que mais crescem na economia agrícola dos Estados Unidos e a produção do bagre-do-canal ou catfish (Ictalurus punctatus) é responsável por $70 \%$ do total de peixes cultivados em tanques escavados. Em 2001, as fazendas produtoras desta espécie arrecadaram, cerca de US\$ 470 milhões, sendo que, em $60 \%$ dessas fazendas foi detectado o off flavor (ESTADOS UNIDOS, 2003).

No Brasil, até há pouco tempo, os piscicultores não se preocupavam com a qualidade do peixe produzido. A produção era voltada quase que exclusivamente para atender a demanda de pesqueiros, que apenas faziam exigências quanto à entrega do peixe vivo, em boas condições, e visualmente isentos de doenças e parasitos. Com o atual declínio econômico da pesca recreativa e a necessidade crescente da industrialização, espera-se que se estabeleçam novos parâmetros que contemplem as exigências do mercado varejista e dos consumidores quanto à qualidade dos produtos de pescado, em especial o frescor e a padronização quanto ao sabor, textura, e coloração da matéria-prima. (Kubitza, 1999). Os produtores que não se adequarem a essa nova 
condição, fatalmente sofrerão com a perda de competitividade e espaço em um mercado consumidor cada dia mais exigente.

\subsubsection{Utilização de algicida para controle de algas.}

Muitas vezes, com o objetivo de controlar o desenvolvimento de certas espécies de algas em mananciais para abastecimento público, as Companhias de Saneamento aplicam doses de sulfato de cobre como algicida (Mcguire et al, 1984). No entanto, ao efetuarem a sua aplicação no manancial, o cobre pode causar a ruptura da parede celular das algas, permitindo a liberação dos eventuais compostos causadores de gosto e odor para a fase aquosa, o que pode trazer prejuízos significativos à qualidade de água. Conforme reportado por Means et al. (1986), a Metropolitan Water District of Southern California (MWDSC) tem observado que, imediatamente após o tratamento da água bruta nos mananciais para abastecimento público, há aumento nas concentrações de MIB e GEO na fase aquosa. Do mesmo modo, a aplicação de sulfato de cobre também pode, ao ocasionar a lise celular, permitir a liberação de toxinas produzidas por cianobactérias.

Pesquisas efetuadas por Peterson et al. (1995), indicaram que a aplicação do sulfato de cobre e dos agentes oxidantes cloro, permanganato de potássio e peróxido de hidrogênio não apenas causaram a inibição de determinadas atividades metabólicas das algas, como também causaram a sua lise celular e liberação para o meio aquoso de carbono orgânico dissolvido (COD) e GEO. Para todos os agentes oxidantes empregados na investigação experimental, observou-se a ruptura da parede celular dos microrganismos na faixa de concentrações comumente empregadas no tratamento de águas de abastecimento, para dosagens de cloro livre, peróxido de hidrogênio e permanganato de potássio superiores a $1,0 \mathrm{mg} \mathrm{Cl}_{2} / \mathrm{l}$, valores estes muito superiores ao limite máximo observado para a não ruptura da parede celular.

\subsection{A tilápia como matéria-prima}

O potencial piscícola da tilápia do Nilo para pequenos criadores se deve ao fato desta espécie ser resistente ao manuseio e transporte, de arraçoamento fácil e 
econômico, crescimento rápido e resistente a baixas concentrações de oxigênio dissolvido, além de apresentar carne de sabor apreciado e com poucas espinhas (Freitas \& Gurgel, 1984).

A tilápia do Nilo (Oreochromis niloticus) com aproximadamente 37\% de porção comestível, é atualmente, a espécie de maior volume de produção da piscicultura, com produção estável e aceitação por parte do consumidor, a qual vem sendo comercializada nos Estados Unidos na forma de filés resfriados e congelados com preço de mercado competitivo. É um peixe de águas paradas, bastante rústico, apresenta alta taxa de prolificidade, é tipicamente herbívoro e sua carne é de sabor agradável, apresenta pouca susceptibilidade a doenças parasitárias, alto teor de domesticidade, resistência a baixas concentrações de oxigênio e grande precocidade. Sua introdução na aqüicultura nacional apresenta-se bastante promissora, além de ser a espécie mais difundida e recomendada para a criação intensiva em tanques e açudes (Bard, 1980; Castagnolli, 1992; Vaz \& Parreira, s.d.).

De acordo com Fitzsimmons (2000), o cultivo de tilápias se encontra amplamente distribuído no mundo inteiro, podendo atingir uma produção mundial de 1.500.000 t em 2010. Por serem consideradas de grande importância para a aqüicultura mundial, vêm sendo bastante indicada para o cultivo intensivo.

Segundo Vannuccini (1999), a tilápia do Nilo tem sido considerada "o novo pescado branco". A espécie os requisitos típicos dos peixes preferidos pelo mercado consumidor, tais como carne branca de textura firme e sabor delicado, de fácil filetagem, ausência de espinhas em "Y", além das características produtivas que colocam a tilápia entre as principais espécies cultivadas comercialmente (Jory et al., 2000).

\subsection{Off flavor em pescado}

Sabe-se que os peixes, tanto de água salgada como os de água doce, são muito suscetíveis à absorção de substâncias químicas presentes em seu ambiente. Porém, notase que essa absorção é mais acentuada em pescado de água doce, porque a água contendo as substâncias odoríferas passa diretamente através de suas guelras, enquanto 
que em pescado de água salgada a transmissão de odores é muito mais lenta, devido à menor permeabilidade das guelras (Reineccius, 1979).

Tabachek \& Yurkowski (1976) verificaram que as trutas dos lagos salgados do sudoeste de Manitoba, Canadá, apresentavam odor “de barro” ou “lodo” devido à presença de algas azuis. Os autores isolaram culturas dessas algas produtoras da geosmina (trans-10, dimetil, trans-9, decalol), substância responsável pelo problema.

Segundo Ploeg \& Body (1992), a maior causa do aparecimento de off flavor em pescado é a geosmina (GEO) que é excretada na água por algas azuis-verdes e por actinomicetos.

A GEO é um óleo neutro que reage com o ácido hidroclórico e é transformada em argosmina, uma substância que possui propriedades semelhantes, embora não idênticas, pois não possui odor. Certos tipos de actinomicetos produzem um odor que é causado por um composto orgânico que é ligeiramente solúvel em água, volátil em vapor, solúvel em éter e parcialmente solúvel em álcool.

Segundo Johnsen (1991) além da GEO (substância eliminada pela Anabaena spp, alga azul-verde) uma outra substância também causa o off flavor em peixes, a MIB (substância eliminada pela Oscillatoria spp).

Segundo Grimm et al. (2004) 80\% dos peixes, com problemas organolépticos, são rejeitados devido ao seu sabor e odor de "barro". Essas características ocorrem devido a presença de MIB ou de GEO. Freqüentemente a mistura desses dois compostos estão presentes.

O sabor indesejável em peixes, associado ao uso de rações comerciais, é raramente observado. A maioria dos grãos, farelos e farinhas de origem animal e vegetal usados nas rações não alteram o sabor e odor dos filés de peixes de maneira detectável pelos consumidores, embora possam causar diferenças na pigmentação (coloração) e textura da carne, dependendo do tipo de ingrediente utilizado e do seu nível de inclusão nas rações (Kubtiza, 2000).

Segundo Kubtiza (2000) a ocorrência de off flavor é mais freqüente em peixes cultivados intensivamente em viveiros, onde os altos níveis de arraçoamento, e conseqüente acúmulo de nutrientes favorece a intensa proliferação de algas cianofíceas 
(Oscillatoria spp, Anabaena spp e Simploca spp) e fungos actinomicetos. Estes organismos são responsáveis pela produção de GEO, associadas ao sabor ou odor de terra ou barro, e MIB, responsável pelo sabor ou odor de mofo em peixes de piscicultura. Peixes cultivados em "raceways" ou tanques-rede também podem apresentar off flavor, dependendo da qualidade da água neste sistema de produção. O off flavor causado pela absorção de GEO e MIB é o predominante em piscicultura intensiva.

O cultivo de tilápias em tanques-rede ou gaiolas vem crescendo consideravelmente no Brasil e em diversos países onde existem grandes reservatórios. Entre muitas outras vantagens, em relação ao cultivo em tanques-terra, o cultivo de tilápias em tanques-rede geralmente reduz a incidência de problemas com off flavor (Kubtiza, 2000).

\subsection{Depuração como medida de prevenção e controle do off flavor}

Pillay (1974) enumerou os fatores que podem melhorar a qualidade dos peixes criados, como a seleção genética, a melhoria de alimentação, o controle do meio ambiente e a utilização de técnicas especiais. Dentre estas, estaria a utilização dos tanques-rede para peixes de fundo, que permaneceriam em jejum ou com alimentação especial sob fluxo de água limpa. Na Inglaterra, esta técnica é empregada em trutas, solha e linguado.

Segundo Beveridge $(1984 ; 1987)$ existem vários fatores que influenciam a capacidade de suporte, o desempenho e a sobrevivência da criação de peixes em gaiolas ou tanques-rede, sendo que a escolha da espécie, qualidade da água, dimensões dos tanques-rede, alimentação e a densidade de estocagem, são os principais fatores que afetam o sucesso da criação neste sistema.

Segundo Kubtiza (2000) ainda não foram identificadas estratégias eficazes para evitar a ocorrência de GEO e MIB nos peixes. No entanto, os produtores de catfish nos Estados Unidos adotaram as seguintes práticas:

- sistema de produção com múltiplas colheitas e estocagem, possibilitando várias opções de viveiros para colheita seletiva em um mesmo momento. 
- avaliação sensorial (degustação) de amostras de peixes dos viveiros em condições de colheita. A autorização final para despesca depende do aval dos degustadores.

- colheita imediata dos viveiros com peixes sem off flavor. Devido à característica transitória do off flavor em peixes, a despesca em viveiros com peixes com sabor indesejável é adiada até o restabelecimento do adequado sabor nos peixes.

A prática de depuração é comumente empregada para moluscos em várias regiões do mundo, com o objetivo de diminuir a carga microbiana destes alimentos, em tratamento da água por raios ultravioleta, durante 48 h. A prática é recomendada devido a prováveis problemas de poluição e contaminação das áreas de cultivo. O processo é mais eficiente se houver água corrente que é recirculada por meio de filtros, e quando emprega tratamento com cloro, luz ultravioleta ou ozônio. Há casos de manutenção do pescado vivo até a comercialização para espécies de crustáceos devido à rápida deterioração, porém o tempo é limitado, havendo necessidade de oxigenação da água para evitar o aparecimento de espécimes moribundas (Connell, 1975; Martin, 1988).

Lovell (1976) verificou que os bagres (Ictalurus punctatus) cultivados em regime intensivo apresentaram odor indesejável, perdendo seu sabor característico pelo fato de absorverem material orgânico proveniente de resíduos agrícolas-industriais, apesar da presença de microorganismos sintetizadores desses componentes, capazes de minimizar o problema de inversão do aroma e sabor nos peixes. O autor trabalhou com tanques onde predominavam algas das espécies Symploce muscorum e Oscillatoris tenuis deixando-os 1, 2, 4, 6, 10 e 14 dias e, a seguir submetendo-os à análise sensorial para depois levá-los à depuração em água filtrada por 3, 6, 10, 15 dias e à nova análise sensorial. O odor indesejável predominou em maior intensidade no tanque com $S$. muscorum; o conteúdo estomacal revelou consumo moderado de algas. Os peixes dos tanques abastecidos apenas com água filtrada oriunda dos tanques com as algas cultivadas, também desenvolveram o mau odor; portanto, os peixes absorveram a geosmina, presente nas algas e dissolvidas na água através das guelras, indo daí para o sangue. A depuração do off flavor foi conseguida após 10 dias. Houve predominância nos tanques da alga Anabaena sirceneria que cresce intensamente a $21^{\circ} \mathrm{C}$, diminuindo, 
porém seu crescimento nas camadas abaixo da superfície devido à falta de luz e menor temperatura. Nas águas mais frias os responsáveis pelo odor indesejável passam a ser os actinomicetos, uma vez que as algas têm seu crescimento limitado pela temperatura. Em tanques, cujo lodo do fundo foi mantido em suspensão por injeção de ar próximo ao fundo, o crescimento das algas foi pequeno, mas o desenvolvimento dos peixes foi satisfatório, assim como seu sabor. A depuração feita em água filtrada a 15 , 22 e $26^{0} \mathrm{C}$ por 15 dias provou que o processo é mais rápido a uma temperatura maior, porém há grande perda de peso dos peixes, podendo se tornar antieconômica.

Em peixes canadenses provenientes dos lagos, é análise de rotina a avaliação de provável off flavor adquirido pelo consumo de algas e conseqüente presença de GEO na carne. A análise sensorial determina quais as áreas que apresentam o problema e assim os peixes são depurados antes da entrada na indústria (Oetterer, 2002).

Segundo Iredale (1974), pesquisas foram conduzidas objetivando detectar as causas do off flavor, em algumas espécies de peixes, bem como as provávies soluções para eliminar o problema seletivo aos fungos actinomicetos e algas azuis nos lagos americanos e as algas produtoras de geosmina em trutas dos lagos canadenses. De acordo com Lovell (1976) a depuração de 10 dias é recomendada para o catfish (Ictalurus punctatus) com off flavor devido a alga Anabaena presente nos tanques de cultivo. Iredale \& York (1976) estabeleceram cinco dias de depuração em ambiente artificial ou 16 em ambiente aberto para a depuração de trutas - "rainbow trout” (Salmo gairdneri) provenientes dos lagos canadenses.

No caso do pescado cultivado de água doce a prática de depuração é recomendada, particularmente se o pescado foi criado em sistemas semi-intensivos e em tanques - rede, para eliminar o off flavor adquirido devido a ingestão de certos tipos de algas. A depuração de tilápias do Nilo criadas pela Companhia Energética de São Paulo-CESP, na represa de Ibitinga, no Rio Tietê, SP, foi testada em vários períodos (1, 2, 3, 4, 9 e, 15 dias), mas só após nove dias, os peixes apresentaram qualidade sensorial para consumo, porém com perda de peso (Torloni et al., 1983).

Ayroza (1995) orienta a despesca de peixes cultivados com depuração que pode ser feita no próprio viveiro de cultivo, através do corte do fornecimento de 
qualquer tipo de alimentação de três a cinco dias antes da despesca, ou através de depuração em tanques de alvenaria; neste caso realiza-se a despesca total do viveiro, colocando-se todos os peixes no tanque de alvenaria construído para esta finalidade, com constante renovação de água, durante 48 horas.

Lovshin (1997) relata que a tilápia absorve off flavor produzido por algas azuis-verdes e outros microrganismos, assim, para assegurar a qualidade do peixe, a tilápia deve ser mantida em água limpa por três a cinco dias para depurar o off flavor.

Segundo Kubtiza (2000) peixes expostos a MIB e GEO adquirem off flavor em poucas horas. No entanto, a eliminação destes compostos pode levar vários dias ou mesmo semanas. Peixes com off flavor podem ser depurados em tanques recebendo fluxo contínuo de água limpa. O uso de tanques de depuração geralmente é restrito aos frigoríficos de pequeno porte devido à necessidade de um considerável volume de água para depuração de grandes quantidades de peixes. A degustação prévia dos peixes prontos para a despesca pode poupar a necessidade de depuração caso as amostras apresentem adequado sabor. O tempo necessário para a depuração de peixes com off flavor depende de diversos fatores, entre muitos a temperatura da água nos tanques de depuração, o teor de gordura dos peixes e a intensidade inicial do off flavor.

Embora o baixo teor de gordura no filé das tilápias possa favorecer a rápida eliminação de compostos associados ao off flavor, o metabolismo reduzido sob baixas temperaturas pode exigir períodos de depuração de uma semana, ou ainda mais longos, para o restabelecimento do sabor adequado. Desta forma, infecções por fungos e bactérias podem ocorrer antes da depuração ser completada, causando mortalidade ou a depreciação da imagem do produto, principalmente, quando este for comercializado inteiro ou em forma de filé com pele (Kubtiza, 2000).

\subsection{Defumação como meio de mascarar o off flavor}

A defumação, segundo Sanchez (1989), é mais indicada para pescado gorduroso, pois as gotículas de gordura ajudam a retenção dos compostos aromáticos da fumaça, que exercem não só a função de conferir sabor e odor agradáveis ao produto, 
mas também de aumentar a durabilidade dos mesmos, por lubrificá-los, impedindo a desidratação.

Segundo Szenttamásy et al. (1993), a operação de defumação consiste na destilação destrutiva da madeira que, pelo calor, desprende compostos voláteis. Nestes compostos, há substâncias que possuem poder bactericida e, portanto, conservador como aldeídos, fenóis e ácidos alifáticos. Porém, a ação de fungos não é inibida.

O princípio da defumação é, em seus pontos essenciais, único, consistindo em expor o peixe fresco ou ligeiramente salgado à ação do calor e da fumaça, produzidos por uma mistura de lenha, gravetos e serragem (Sanchez 1989).

O pescado é um alimento extremamente perecível devido à elevada atividade de água, composição química, teores de gorduras insaturadas facilmente oxidáveis e, principalmente, ao pH próximo da neutralidade (Melo Franco \& Landgraf, 1996). Devido às características intrínsecas, os processos de conservação do pescado in natura e de transformações tecnológicas ganham importância especial. Dentre elas, tem-se os peixes defumados, cuja principal finalidade atualmente é proporcionar ao produto características organolépticas desejáveis, como a cor, aroma, sabor e textura reduzindo a atividade de água através da desidratação e pH, pela ação dos compostos da fumaça, evitando a ação microbiológica com conseqüente aumento da vida útil do produto pronto para o consumo (Souza, 2003).

A defumação aplicada a espécies de menor valor pode aumentar sua qualidade, devido às características de sabor, aroma e cor, proporcionadas ao produto com o processo de defumação. Desta forma, tornam-se necessárias investigações sobre métodos de preservação para posterior processamento, forma de apresentação do produto (inteiro eviscerado, filé com e sem pele ou espalmado) e influências de suas características intrínsecas sobre a qualidade do produto. Segundo Amerio et al. (1996) a homogeneidade no tamanho do peixe, também, é um fator de qualidade. De acordo com Morkore et al. (2001), existe carência de informações sobre a influência da composição do material in natura sobre a qualidade do produto final defumado. 
Segundo Clucas \& Ward (1996) o processo de defumação é um método que mascara o off flavor em pescado. O uso de uma solução de ácido acético com sal marinho também é um método utilizado para mascarar o off flavor em pescado.

Em nosso país já foi testado o efeito da defumação a quente e a frio em mandis (Pimelodus clarias). A carne deste tipo de pescado normalmente não é bem aceita por ter um sabor bem característico de peixe de rio e, portanto, possuir off flavor. A utilização da defumação a frio para mandis propiciou a obtenção de um produto que apresentou uma grande melhora na qualidade do sabor da carne em relação ao peixe cozido ou frito (Andrade \& Lima, 1975). A defumação a quente aplicada aos mandis serviu para mascarar este problema, também resultando em um produto bem aceito (Andrade \& Lima, 1983).

\subsection{Análise sensorial como meio de avaliar o off flavor}

Os métodos sensoriais são muito antigos, mas ainda bastante usados pra avaliar a qualidade do pescado. Nos mercados e indústrias processadoras de pescado, o controle de qualidade deve ser feito por pessoas adequadamente treinadas e os itens utilizados para julgamento são: aspecto geral (olhos e guelras), textura, sabor, odor e cor de partes específicas como carne, pele e guelras (Ogawa \& Maia, 1999).

O grau de aceitabilidade de um alimento por parte dos consumidores é afetado por fatores próprios de cada indivíduo e do ambiente que o circunda. De muita influência são os hábitos e padrões culturais, além da sensibilidade individual, muito variável com a pessoa e a idade desta (Dasso, 1999).

Beirão et al. (2000) definem a análise sensorial, como uma técnica utilizada para evocar, medir, analisar e interpretar reações às características dos alimentos quando são percebidas pelos órgãos dos sentidos; é a avaliação mais freqüente na indústria de pescado e derivados, tanto pela necessidade da rapidez do julgamento de lotes de matéria-prima e do produto acabado, como pela facilidade de execução.

A cor e a textura são propriedades sensoriais muito importantes de um alimento, sendo mais fáceis de se avaliar do que o sabor, pois este se constitui em um fenômeno completo e dinâmico, que relaciona todos os sentidos, principalmente o 
olfato e o gosto. O olfato compõe a fisiologia do sabor porque, o aroma é o primeiro atributo que se percebe, antes até que o gosto. Um odor inadequado pode interferir ou modificar um determinado sabor (Lozano, 1999).

Segundo Huss et al. (1974) a análise sensorial completa, é a que permite a avaliação do frescor do pescado, visando um melhor aspecto quanto a qualidade do produto. Nenhum teste químico, por si, pode ser considerado satisfatório para medir o grau de deterioração do pescado, portanto, a análise sensorial tem sido usada como principal parâmetro coadjuvante da avaliação da qualidade do pescado.

Testes de avaliação podem ser feitos por degustação da carne da tilápia submetida à cocção por microondas ou em vapor, sem condimentação para facilitar a análise sensorial e se constituem na única forma de avaliação dos peixes de determinados criatórios sobre o problema (Lovshin, 1997). 


\section{INFLUÊNCIA DA QUALIDADE DA ÁGUA NO SABOR E ODOR DE PEIXES CULTIVADOS}

\section{Resumo}

A busca dos produtores pelo melhor desempenho produtivo de seus peixes, visando uma produção altamente lucrativa, tem acentuado o problema da eutrofização das águas utilizadas nos cultivos. Já existe consenso de que a qualidade da água interfere na qualidade do sabor do pescado. Este conhecimento é muito importante para a tomada de medidas preventivas, tanto econômicas, quanto na manutenção racional da água utilizada por parte dos aquicultores. Buscou-se neste trabalho relacionar as principais causas relacionadas à água que resultam em sabores e odores desagradáveis no pescado cultivado. O monitoramento da qualidade da água iniciou-se com as análises microbiológicas, físico-químicas e biológica dos tanques de cultivo e de depuração. A água do tanque de cultivo apresentou problemas de eutrofização e presença de geosmina, ao contrário da água do tanque de depuração que apresentou-se límpida e ausente de geosmina. Através da analise qualitativa e quantitativa de algas e cianobactérias verificou-se que a água do tanque de cultivo apresenta concentrações altas de cianobactérias que causam odor e sabor de “barro” na água.

\section{Summary}

Producers' search for a better productive performance of their fish in order to obtain a highly profitable production has increased the problem of eutrophication in cultivation waters. It is generally agreed that water quality interferes with the quality of the fish flavor. This knowledge is important for preventive measures both in the economy and the rational maintenance of the water used by fish farmers. In this work, 
we attempted to describe the main water-related caused resulting in unpleasant flavors and odors in cultured fish. The monitoring of the water quality was initiated by microbiological, physical-chemical, and biological analyses of the cultivation and depuration tanks. The water from the cultivation tanks presented eutrophication problems and the presence of geosmin was detected, unlike the water from the depuration tanks, which were clear and geosmin-free. Through the qualitative and quantitative analyses of algae and cyanobacteria, we determined that the water from the cultivation tank has high concentrations of cyanobacteria which give the water a "mud" flavor and odor.

\subsection{Introdução}

A produção mundial de pescado, segundo estimativas da Food and Agricultural Organization of the United Nation-FAO, cresceu consideravelmente durante a segunda metade do século XX, saltando de pouco mais de 20 milhões de toneladas no início dos anos 50 para 100 milhões de toneladas no final dos anos 80. A produção global da aqüicultura foi estimada em 12,7 milhões de toneladas em 1991, equivalendo a, aproximadamente, $13 \%$ de toda a produção pesqueira (Wilde \& Kamistra, 1999).

O processo de eutrofização constitui-se no enriquecimento das águas por nutrientes, especialmente nitrogênio e fósforo, cujo resultado mais comum é o crescimento excessivo de plantas aquáticas, que podem ser tanto as que se movimentam livremente na água, como é o caso das comunidades fitoplanctônicas, quando as plantas flutuantes ou submersas, como exemplo os conhecidos aguapés (Eichchornia crassipes e Eichchornia azurea). O processo não é função exclusivamente da presença de nutrientes na água, mas é controlado também por fatores físicos ambientais naturais, entre os quais se destacam a transparência, a temperatura da água, estrutura térmica bem como o regime hidráulico do corpo de água (Companhia de Tecnologia de Saneamento Ambiental - CETESB, 2000).

Armstrong et al (1986), estudaram os fatores ambientais que poderiam afetar o sabor do “catfish” em tanques de produção da região do Alabama (EUA) e verificaram 
que o sabor de "barro" havia sido mais severo no final do verão quando a atividade algal e microalgal nos viveiros foram altas em resposta às elevadas taxas de fornecimento de alimento. É possível que as taxas de absorção dos compostos geradores do sabor de "terra” ou "mofo" sejam influenciadas pela concentração da substância ativa, o tempo de exposição ao composto, qualidade da água e estado fisiológico do peixe (Persson, 1984). Grandes quantidades de matéria orgânica podem causar problemas de sabor e odor na água pela formação de substrato para o crescimento de actinomicetos produtores de GEO e MIB (Tucker \& Martin, 1991). Da mesma forma, Brown \& Boyd (1982) suspeitaram da relação entre off flavor e taxas de arraçoamento na região do oeste central do Alabama, já que as taxas de alimento inserido nos viveiros de criação de “catfish” por eles estudados vinham aumentando ao longo dos anos que antecederam o estudo, favorecendo o crescimento de algas e actinomicetos.

Existem evidências sobre a relação entre qualidade de água e qualidade do sabor do peixe, no entanto, como observaram Tucker \& Martin (1991) e Lovell (1976), os fatores ambientais envolvidos na ocorrência de GEO e MIB ainda não são totalmente conhecidos e existem muitas informações contraditórias na literatura. No estudo de Armstrong et al (1986), estas contradições são evidentes; apesar de ter-se detectado off flavor em viveiros de criação de “catfish” da região do Alabama, não foi possível relacionar as características limnológicas dos viveiros com a ocorrência do mesmo, evidenciando a complexidade da ocorrência do off flavor, que foi detectado em águas de cultivo cujas características limnológicas diferiam completamente entre si, inclusive entre características apontadas na literatura como propícias a ocorrência de organismos sintetizadores de GEO e MIB. Sabe-se, porém, que a qualidade da água é negativamente alterada quando as taxas de arraçoamento são elevadas (Boyd et al, 1978; Cole \& Boyd, 1986). 


\subsection{Material e métodos}

\subsubsection{Procedimento para coleta da água de cultivo e do tanque de depuração}

As coletas de água foram realizadas em um criatório da região de Artur Nogueira-SP e, também no tanque de depuração localizado no Departamento de Zootecnia da ESALQ-USP. Foram realizadas 3 coletas, em três pontos escolhidos em todo o lago nos dias 04/03, 18/03 e 25/03/2004, sempre uma semana antes da despesca. No tanque de depuração foi realizada uma única coleta no dia 04/03/2004 para as análises físico-químicas, um dia antes da chegada dos peixes, e três coletas para as análises microbiológicas.

A coleta da água foi efetuada, manualmente, seguindo recomendações de Agudo (1988). Os frascos foram imersos na posição invertida, $30 \mathrm{~cm}$ abaixo da superfície da água e foram inclinados lentamente, a fim de permitir a saída do ar e, conseqüentemente, o enchimento dos mesmos, os quais foram fechados, imediatamente.

\subsubsection{Análises microbiológicas}

Foram utilizados frascos de vidro neutro de borossilicato com capacidade para $1 \mathrm{~L}$, os quais foram previamente envoltos em papel pardo e esterilizados por $2 \mathrm{~h}$, em estufa Fanem, modelo 315 SE, a temperatura de 170-180 ${ }^{0} \mathrm{C}$. Após a coleta da água descrita no item 3.2.1, os frascos foram colocados em um recipiente isotérmico contendo gelo e foram levados, diretamente, ao Laboratório de Microbiologia do Departamento de Agroindústria, Alimentos e Nutrição da ESALQ-USP, onde foram conduzidas as análises descritas a seguir:

\subsubsection{Coliformes totais e coliformes fecais}

Utilizou-se a técnica de tubos múltiplos, série de 5 tubos de Número Mais Provável (NMP). Para a prova presuntiva, inoculou-se $10 \mathrm{~mL}$ de água nos 5 tubos contendo Caldo Lauril Sulfato de Sódio em concentração dupla. Inoculou-se volumes de $1 \mathrm{~mL}$ da amostra em uma série de 5 tubos contendo Caldo Lauril Sulfato de Sódio em concentração simples, e volumes de $1 \mathrm{~mL}$ da diluição $10^{-1}$, em outra série de 5 tubos 
contendo o mesmo meio. Os tubos foram inoculados a $36^{\circ} \mathrm{C} \pm 1^{\circ} \mathrm{C}$ por 48 horas. A positividade foi indicada pelo crescimento e presença de gás nos tubos de Duhram. Para a confirmação de coliformes totais, repicou-se os tubos positivos de Caldo Lauril Sulfato de Sódio para tubos de Caldo Verde Brilhante Bile 2\% lactose, que foram incubados a $36^{\circ} \mathrm{C} \pm 1^{\circ} \mathrm{C}$ por $48 \mathrm{~h}$. Para a prova confirmatória de coliformes fecais, repicou-se os tubos positivos de Caldo Lauril Sulfato de Sódio para tubos de caldo EC, incubando-os a $45^{\circ} \mathrm{C} \pm 0,2^{\circ} \mathrm{C}$, por $48 \mathrm{~h}$ em banho-maria com agitação. A presença de gás indica positividade do tubo para a presença de coliformes fecais. Através da combinação do número de tubos positivos em cada série de diluição nos testes para coliformes totais e fecais e consultando-se a Tabela de Número Mais Provável, obtevese NMP de coliformes fecais/mL de amostra e coliformes totais (American Public Health Association - APHA, 1998; Hitchins, et al., 2004).

\subsubsection{Análises físico-químicas}

Após a coleta da água, descrita no item 3.2.1, as amostras foram levadas, diretamente, ao Laboratório de Ecologia Aplicada do Departamento de Ciências Florestais da ESALQ-USP para análises descritas a seguir:

3.2.3.1 Alcalinidade: a alcalinidade foi medida segundo metodologia de Mackereth et al. (1978).

3.2.3.2 Fósforo total: realizada a partir da digestão química dos fosfatos e colorimetria com espectrofotômetro (APHA, 1992).

3.2.3.3 Nitrogênio amoniacal: determinado através do método colorimétrico realizado por Korolff (ANON, 1983)

3.2.3.4 Condutividade elétrica: realizada através de um condutuvímetro da marca YSI.

3.2.3.5 pH: determinado através de um potenciômetro digital Digimed. 
3.2.3.6 Dureza total: calculado com base no equivalente de Carbonato de cálcio segundo APHA (1995).

3.2.3.7 Oxigênio dissolvido: realizada através de um oxímetro da marca YSI.

3.2.3.8 Transparência: a transparência foi determinada com a ajuda de um disco de Secchi de 25 centímetros de diâmetro (Kubitza, 2003).

3.2.3.9 Temperatura: utilizou-se um termômetro de mercúrio com escala de 0 a $40^{\circ} \mathrm{C}$.

\subsubsection{Determinação de geosmina}

Após a coleta da água, descrita no item 3.2.1, as amostras foram levadas, diretamente, ao laboratório da BIOAGRI localizado em Piracibaca - SP. A concentração de geosmina presente na água de cultivo foi analisada aplicando cromatografia gasosa e espectrofotometria.

\subsubsection{Análises qualitativas e quantitativas de algas e cianobactérias}

Após a coleta da água, descrita no item 3.2.1, as amostras foram conservadas por 2 meses em frascos âmbar e em local sem iluminação e levadas ao laboratório da BIOALGAS localizado em São Paulo - SP.

As análises qualitativas das algas e cianobactérias foram feitas com material fixado com solução de formol a 4\%. As amostras foram examinadas em microscópio óptico binocular com câmara clara e ocular de medição acoplada.

As amostras para as análises quantitativas foram fixadas com solução de lugol, segundo metodologia de Utermhl (1958). As amostras para contagem foram colocadas em câmara de sedimentação conforme a concentração da amostra e, desta forma, utilizou-se câmara de $2 \mathrm{ml}$ para as 3 amostras da água de cultivo e de $50 \mathrm{ml}$ para a amostra da água de depuração. A contagem do número de células foi feita em microscópio invertido em aumento de 320 vezes. 


\subsection{Resultados e discussão}

\subsubsection{Análises microbiológicas}

\subsubsection{Análise da água de cultivo}

A Tabela 1 apresenta os valores da contagem de coliformes totais e fecais presentes na água de cultivo de tilápias nos dias 04/03, 18/03 e 25/03/2004. A legislação brasileira estabelece limites de $\leq 5 \times 10^{3}$ para coliformes totais, e $\leq 1 \times 10^{3}$ para coliformes fecais/100 mL de água, destinada à preservação de peixes em geral (BRASIL, resolução CONAMA n²20, 2004b).

Tabela 1. NMP/100mL de coliformes totais e coliformes fecais em água de cultivo

\begin{tabular}{ccc}
\hline Amostras & Coliformes Totais & Coliformes Fecais \\
\hline $04 / 03$ & $3,5 \times 10^{2}$ & 6,8 \\
$18 / 03$ & $5,4 \times 10^{2}$ & $3,3 \times 10$ \\
$25 / 03$ & $2,4 \times 10^{2}$ & $1,7 \times 10$ \\
\hline
\end{tabular}

* Médias de 3 repetições.

Todos os valores encontrados de coliformes fecais e totais estão dentro dos permitidos pela legislação.

\subsubsection{Análise da água de depuração}

A Tabela 2 apresenta os valores de NMP de coliformes totais e fecais presentes na água de depuração de tilápias nos três dias de coleta, sendo que no dia 04/03 o tanque ainda não havia recebido os peixes; no dia 24/03 os peixes estavam no $5^{\circ}$ dia de depuração e no dia 02/04 haviam peixes no $7^{\circ}$ dia de depuração. Todos os valores encontrados de coliformes totais e fecais estão dentro dos permitidos pela legislação. 
Tabela 2. NMP/100mL de coliformes totais e coliformes fecais em água de depuração

\begin{tabular}{ccc}
\hline Amostras & Coliformes Totais & Coliformes Fecais \\
\hline $04 / 03$ & $9,2 \times 10^{2}$ & 4,5 \\
$24 / 03$ & $5,4 \times 10^{2}$ & $1,4 \times 10$ \\
$02 / 04$ & $3,3 \times 10$ & $1,1 \times 10$ \\
\hline
\end{tabular}

* Médias de 3 repetições

\subsubsection{Análises Físico-químicas e de geosmina da água de cultivo e de depuração}

\subsubsection{Alcalinidade Total}

A Tabela 3 apresenta os valores de alcalinidade na água de cultivo e na água de depuração. Segundo Kubitza (2003), a água com alcalinidade total inferior a 20mg $\mathrm{CaCO}_{3} / \mathrm{L}$ apresenta reduzido poder tampão e pode apresentar significativas flutuações diárias nos valores de $\mathrm{pH}$, em função dos processos fotossintéticos e respiratórios nos viveiros. Os valores encontrados para alcalinidade na água de cultivo estão abaixo dos recomendados pelo autor, conseqüentemente, poderão ocorrer oscilações diárias nos valores de $\mathrm{pH}$ desta. O valor médio encontrado para a água de depuração está de acordo com as recomendações do autor.

Tabela 3. Alcalinidade $\left(\mathrm{mgL}^{-1}\right)$ na água de cultivo e de depuração

\begin{tabular}{cc}
\hline Amostras & Alcalinidade \\
\hline Água Cultivo (04/03) & 18,6 \\
Água Cultivo (18/03) & 16,0 \\
Água Cultivo (25/03) & 16,0 \\
Água Depuração (04/03) & 113,4 \\
\hline
\end{tabular}

* Médias de 3 repetições

\subsubsection{Fósforo total}

Os valores encontrados para fósforo total na água de cultivo e de depuração estão na Tabela 4. O fósforo total deve, segundo a legislação (BRASIL, 2004b), apresentar-se em um teor de, no máximo, 0,025mg/L. Pode-se verificar que, tanto no 
tanque de cultivo, como no de depuração, este índice foi um pouco maior, resultando em uma maior disponibilidade de nutrientes e, portanto um maior desenvolvimento de fitoplâncton.

Tabela 4. Fósforo $\left(\mathrm{mgL}^{-1}\right)$ na água de cultivo e de depuração

\begin{tabular}{cc}
\hline Amostras & Fósforo \\
\hline Água Cultivo (04/03) & 0,07 \\
Água Cultivo (18/03) & 0,05 \\
Água Cultivo (25/03) & 0,07 \\
Água Depuração (04/03) & 0,03 \\
\hline * Médias de 3 repetições &
\end{tabular}

\subsubsection{Nitrogênio Amoniacal}

Os valores encontrados para nitrogênio amoniacal na água de cultivo e de depuração estão na Tabela 5. Níveis abaixo de 0,15 mg de amônia $\left(\mathrm{NH}_{3}\right) / \mathrm{L}$, são considerados seguros no cultivo de pescados como camarões e peixes tropicais (Boyd, 1997), portanto os valores encontrados tanto na água de cultivo como na água de depuração não estão em níveis adequados para o cultivo de tilápias.

Tabela 5. Nitrogênio Amoniacal (mgL $\left.{ }^{-1}\right)$ na água de cultivo e de depuração

\begin{tabular}{cc}
\hline Amostras & Nitrogênio Amoniacal \\
\hline Água Cultivo (04/03) & 0,4 \\
Água Cultivo (18/03) & 0,2 \\
Água Cultivo (25/03) & 0,3 \\
Água Depuração (04/03) & 0,2 \\
\hline
\end{tabular}

* Médias de 3 repetições

\subsubsection{Condutividade Elétrica}

Os dados de condutividade elétrica encontrados na água de cultivo e na água de depuração estão dispostos na Tabela 6. Segundo Molle \& Cadier (1992) a 
condutividade elétrica da água é medida pela sua capacidade em conduzir eletricidade, e depende da quantidade de íons nela contidos, constituindo um bom indicador da concentração total de sais na água. A tilápia é uma espécie considerada tolerante, uma vez que resiste a condutividade de 15 a $20 \mathrm{dS} / \mathrm{cm}$. Podemos verificar que os valores encontrados para condutividade elétrica tanto para a água de cultivo, como para a água de depuração, são inferiores ao valor considerado limite a ser tolerado pela tilápia.

Tabela 6. Condutividade elétrica $\left(\mathrm{dSm}^{-1}\right)$ na água de cultivo e de depuração.

\begin{tabular}{cc}
\hline Amostras & Condutividade Elétrica \\
\hline Água Cultivo (04/03) & 8,00 \\
Água Cultivo (18/03) & 7,00 \\
Água Cultivo (25/03) & 7,00 \\
Água Depuração (04/03) & 13,5 \\
\hline
\end{tabular}

* Médias de 3 repetições

\subsubsection{5 pH}

Na Tabela 7 estão apresentados os valores de pH encontrados na água de cultivo e de depuração. Segundo a legislação (BRASIL, 2004b) os valores desejados de $\mathrm{pH}$, em viveiros de aqüicultura, variam de 6,5 a 9,0. Os valores de $\mathrm{pH}$ na água de cultivo variaram de 6,7 a 7,11, estando, portanto, de acordo com os valores recomendados pela legislação; o valor encontrado na água de depuração $(8,5)$ também está dentro dos limites exigidos pela legislação.

Tabela 7. pH na água de cultivo e de depuração

\begin{tabular}{cc}
\hline Amostras & $\mathrm{pH}$ \\
\hline Água Cultivo (04/03) & 6,86 \\
Água Cultivo (18/03) & 7,11 \\
Água Cultivo (25/03) & 6,7 \\
Água Depuração (04/03) & 8,5 \\
\hline * Médias de 3 repetições
\end{tabular}

* Médias de 3 repetições 


\subsubsection{Dureza Total}

Os valores de dureza total da água de cultivo e da água de depuração estão apresentados na Tabela 8. De acordo com Kubitza (2003) a dureza total em viveiros de aqüicultura deve ser superior a $30 \mathrm{mg}$ de $\mathrm{CaCO}_{3} /$ litro. Os valores encontrados na água de cultivo estão abaixo dos valores recomendados e o encontrado na água de depuração está de acordo com o citado pelo autor, uma vez que são superiores ao preconizado, da ordem de 52,3 mg/L.

Água com dureza muito alta apresenta menor diversidade e presença de algas (fitoplâncton) (Pádua, 1994).

Tabela 8. Dureza total $\left(\mathrm{mgL}^{-1}\right)$ na água de cultivo e de depuração

\begin{tabular}{cc}
\hline Amostras & Dureza Total \\
\hline Água Cultivo (04/03) & 15,2 \\
Água Cultivo (18/03) & 12,8 \\
Água Cultivo (25/03) & 13,2 \\
Água Depuração (04/03) & 52,3 \\
\hline
\end{tabular}

* Médias de 3 repetições

\subsubsection{Oxigênio Dissolvido}

Na Tabela 9 estão relacionados os valores de oxigênio dissolvido da água de cultivo e da água de depuração. Segundo a legislação (BRASIL, 2004b) os valores desejáveis de oxigênio dissolvido na água destinada à piscicultura devem ser superiores a 5,0 mg/L. Tanto os valores encontrados para a água de cultivo como os valores encontrados para a água de depuração, estão em níveis aceitáveis. 
Tabela 9. Oxigênio dissolvido $\left(\mathrm{mgL}^{-1}\right)$ na água de cultivo e de depuração

\begin{tabular}{cc}
\hline Amostras & Oxigênio Dissolvido \\
\hline Água Cultivo (04/03) & 8,6 \\
Água Cultivo (18/03) & 6,4 \\
Água Cultivo (25/03) & 9,3 \\
Água Depuração (04/03) & 8,4 \\
\hline
\end{tabular}

* Médias de 3 repetições

\subsubsection{Temperatura}

Segundo Kubitza (2003), a exigência em temperatura depende da espécie que será cultivada e da fase de desenvolvimento em que esta se encontra (ovo, larva, póslarva ou juvenil). As espécies de peixes tropicais, normalmente, apresentam ótimo crescimento a temperaturas de 26 a $30^{\circ} \mathrm{C}$. Na Tabela 10 estão os valores encontrados para a temperatura no tanque de cultivo e no de depuração; os valores estão abaixo do sugerido pelo autor, como ótimo para crescimento.

Tabela 10. Temperatura $\left({ }^{\circ} \mathrm{C}\right)$ na água de cultivo e de depuração

\begin{tabular}{cc}
\hline Amostras & Temperatura ${ }^{\circ} \mathrm{C}$ \\
\hline Água Cultivo (04/03) & 24,7 \\
Água Cultivo (18/03) & 24,7 \\
Água Cultivo (25/03) & 22,3 \\
Água Depuração (04/03) & 21,2 \\
* Médias de 3 repetições &
\end{tabular}

\subsubsection{Transparência}

Na Tabela 11 estão relacionados os valores de oxigênio dissolvido na água de cultivo e na água de depuração. Leituras em disco de Secchi inferiores a $30 \mathrm{~cm}$ correspondem a viveiros eutróficos, com grande quantidade de matéria orgânica e fitoplâncton, podendo apresentar problemas com baixos níveis de oxigênio dissolvido (Kubitza, 2003). Neste trabalho foram encontrados valores na água de cultivo um pouco 
menores que $30 \mathrm{~cm}$, o que caracteriza ambiente eutrófico. Na água de depuração não foi determinada a transparência, pois esta se apresentava límpida.

Tabela 11. Transparência (cm) na água de cultivo e de depuração

\begin{tabular}{cc}
\hline Amostras & Transparência cm \\
\hline Água Cultivo (04/03) & 28,33 \\
Água Cultivo (18/03) & 28,33 \\
Água Cultivo (25/03) & 30,00 \\
Água Depuração (04/03) & n.d
\end{tabular}

\subsubsection{Determinação de geosmina}

Os valores de geosmina da água de cultivo e da água de depuração estão apresentados na Tabela 12. O gosto e o odor de barro em água podem ser causados pela presença dos compostos geosmina e 2-metilisoborneol. Sabe-se, hoje, que estes compostos possuem odor e sabor muito fortes e estes são detectados mesmo em baixas concentrações.

Tabela 12. Geosmina (ng/L) na água de cultivo e de depuração

\begin{tabular}{cc}
\hline Amostras & Geosmina ng/L \\
\hline Água Cultivo (04/03) & 10,00 \\
Água Cultivo (18/03) & 10,00 \\
Água Cultivo (25/03) & 10,00 \\
Água Depuração (04/03) & n.d \\
\hline n.d = não detectado &
\end{tabular}

A presença de geosmina pode ser detectada a partir de 1ng/L (Benanou et.al., 2003). No tanque de cultivo foi detectado, em todos os dias de coleta, um teor de 10ng/L e, no tanque de depuração, não foi detectada geosmina. 


\subsubsection{Análises qualitativas e quantitativas de algas e cianobactérias}

\subsubsection{1 Água de cultivo e de depuração}

$\mathrm{Na}$ análise qualitativa da primeira coleta foram identificados 75 táxons distribuídos em 9 classes (Tabela 13). Verificou-se também a presença de cyanobacteria produtora de microcistina (hepatotoxina) Aphanocapsa cumulus e de algumas espécies de Cyanobacteria potencialmente produtoras de toxina; Aphanocapsa, Cylindrospermopsis sp e Pseudanabaena sp. Também verificou-se a presença de cianobactérias que produzem cheiro de geosmina e 2-metilisoborneol e a presença de algas que podem produzir odor e sabor na água como: Aulacoseira (odor de "gerânio" ou de “terra”), Cyclotella (gosto e odor de “peixe”), Chlamydomonas, Chlorella (odor de “mofo”), Dictyosphaerium (odor e sabor de “capim”), Scenedesmus e Staurastrum (odor de “capim”), Pediastrum (odor e sabor de “peixe”), Cryptomonas (gosto “doce” e odor de "violeta”), Mallomonas (odor de "violeta” e de "peixe”), Peridinium (odor de “pepino” ou de “peixe”) e Euglena (odor e sabor de “peixe”). Na análise quantitativa a densidade total da comunidade algácea está expressa em células/ml, a espécie mais encontrada na água é a Kirchneriella lunaris (2335 células/ml) que pertence a classe Chlorophyceae (Tabela 14).

Tabela 13. Composição e tipo de organismo da comunidade fitoplâncton na amostra 1

\begin{tabular}{ccc}
\hline Táxons & $\begin{array}{c}\mathrm{N}^{\circ} \text { total de táxons por } \\
\text { classe }\end{array}$ & $\begin{array}{c}\text { \% de táxons por } \\
\text { classe }\end{array}$ \\
\hline CYANOBACTERIA (algas azuis) & 4 & 5 \\
Aphanocapsa cumulus & & \\
Aphanocapsa incerta & & \\
Cylindrospermopsis sp & & 10 \\
Pseudoanabaena sp & 7 &
\end{tabular}


Tabela 13. Composição e tipo de organismo da comunidade fitoplâncton na amostra 1

\begin{tabular}{ccc}
\hline Táxons & $\begin{array}{c}\mathrm{N}^{\circ} \text { total de táxons por } \\
\text { classe }\end{array}$ & $\begin{array}{c}\% \text { de táxons por } \\
\text { classe }\end{array}$
\end{tabular}

Aulacoseira sp

Cyclotella meneghiniana

Eunotia sp

Frutulia rhomboides

Navícula sp

Stenopterobia delicatissima

CHLOROPHYCEAE

Actinastrum aciculare

Botryococcus terribilis

Chlamydomonas angulosa

Chlorella kessleri

Chlorella vulgaris

Chlorococcum infusionum

Chloromonas flos-aquae

Choricystis cylindracea

Coccomyxa lacustris

Coelastrum astroideum

Coelastrum reticulatum

Coelastrum sphaericum

Coenochloris ovalis

Crucigenia quadrata

Crucigenia tetrapedia

Crucigeniella crucífera

Dictyosphaerium ehrenbergianum

Dictyosphaerium elegans

Dictyosphaerium tetrachotomum 
Tabela 13. Composição e tipo de organismo da comunidade fitoplâncton na amostra 1

\begin{tabular}{ccc}
\hline Táxons & $\mathrm{N}^{\circ}$ total de táxons por \\
classe & $\begin{array}{c}\% \text { de táxons por } \\
\text { classe }\end{array}$
\end{tabular}

Didymocystis fina

Eutetramorus fottii

Kircheriella lunaris

Kircheriella roselata

Lagerheimia sp

Micractinium pusillum

Monoraphidium arcuatum

Monoraphidium contortum

Monoraphidium longiusculum

Monoraphidium nanum

Monoraphidium tortile

Nephroclamys willeana

Ooscystis lacustris

Pediastrum duplex

Pediastrum tetras

Quadrigula closterioides

Scenedesmus acuminatus

Scenedesmusarcuatus spinosus

Scenedesmus bicaudatus

Scenedesmus caudato-aculeatus

Scenedesmus denticulatus

Scenedesmus opoliensis

Scenedesmus ovalternus

Scenedesmusovalternus graevenitzii

Scenedesmus quadricauda

Scenedesmus spinosus 
Tabela 13. Composição e tipo de organismo da comunidade fitoplâncton na amostra 1

\begin{tabular}{|c|c|c|}
\hline Táxons & $\begin{array}{c}\mathrm{N}^{\circ} \text { total de táxons por } \\
\text { classe }\end{array}$ & $\begin{array}{c}\text { \% de táxons por } \\
\text { classe }\end{array}$ \\
\hline CHRYSOPHYCEAE & 1 & 3 \\
\hline \multicolumn{3}{|l|}{ Mallomonas sp } \\
\hline CRYPTOPHYCEAE & 1 & 3 \\
\hline \multicolumn{3}{|l|}{ Cryptomonas sp } \\
\hline DINOPHYCEAE & 1 & 3 \\
\hline \multicolumn{3}{|l|}{ Peridinium sp } \\
\hline EUGLENOPHYCEAE & 10 & 13 \\
\hline \multicolumn{3}{|l|}{ Euglena acus } \\
\hline \multicolumn{3}{|l|}{ Euglena deses } \\
\hline \multicolumn{3}{|l|}{ Euglena spirogyra } \\
\hline \multicolumn{3}{|l|}{ Lepocinclis fusiformes } \\
\hline \multicolumn{3}{|l|}{ Lepocinclis ovum } \\
\hline \multicolumn{3}{|l|}{ Phacus suecicus } \\
\hline \multicolumn{3}{|l|}{ Strombomonas scabra } \\
\hline \multicolumn{3}{|l|}{ Strombomonas sp } \\
\hline \multicolumn{3}{|l|}{ Trachelomonas híspida } \\
\hline \multicolumn{3}{|l|}{ Trachelomonas volvocina } \\
\hline XANTHOPHYCEAE & 2 & 3 \\
\hline \multicolumn{3}{|l|}{ Goniochloris mutica } \\
\hline \multicolumn{3}{|l|}{ Tetraplektron deniseae } \\
\hline ZYGNEMAPHYCEAE (desmídias) & 2 & 3 \\
\hline \multicolumn{3}{|l|}{ Euastrum sp } \\
\hline Staurastrum sp & & \\
\hline
\end{tabular}


Tabela 14. Densidade do fitoplâncton (células/ml) na amostra 1

\begin{tabular}{|c|c|}
\hline Táxons & Densidade (células/ml) \\
\hline Kirchneriella lunaris & 2335 \\
\hline Dictyosphaerium tetrachotomum & 1760 \\
\hline Coenochloris ovalis & 914 \\
\hline Scenedesmus ovalternus graevenitzii & 812 \\
\hline Crucigenia quadrata & 677 \\
\hline Cylindrospermopsis sp & 609 \\
\hline Scenedesmus ovalternus & 542 \\
\hline Chlorella vulgaris & 474 \\
\hline Coelastrum reticulatum & 474 \\
\hline Scenedesmus quadricauda & 474 \\
\hline Aphanocapsa cumulus & 406 \\
\hline Crucigenia tetrapedia & 406 \\
\hline Choricystis cylindracea & 338 \\
\hline Cryptomonas sp & 237 \\
\hline Aulacoseira distans & 203 \\
\hline Didymocystris fina & 203 \\
\hline Oocystis lacustris & 203 \\
\hline Chlorococcum infusionum & 169 \\
\hline Coelastrum astroideum & 169 \\
\hline Chlorella kessleri & 135 \\
\hline Scenedesmus bicaudatus & 135 \\
\hline Scenedesmus acuminatus & 135 \\
\hline Chlamydomonas angulosa & 102 \\
\hline Monoraphidium nanum & 102 \\
\hline Cyclotella meneghiniana & 68 \\
\hline Monoraphidium contortum & 68 \\
\hline Navícula sp & 68 \\
\hline
\end{tabular}


Tabela 14. Densidade do fitoplâncton (células/ml) na amostra 1

\begin{tabular}{cc}
\hline Táxons & Densidade (células/ml) \\
\hline Euglena acus & 34 \\
Eunotia sp & 34 \\
Lagerheimia sp & 34 \\
Lepocinclis ovum & 34 \\
Monoraphidium arcuatum & 34 \\
Monoraphidium longiusculum & 34 \\
Monoraphidium tortile & 34 \\
\hline
\end{tabular}

$\mathrm{Na}$ análise qualitativa da $2^{\mathrm{a}}$ amostra foram identificados 73 táxons distribuídos em 9 classes (Tabela 15).Verificou-se também a presença de algumas espécies de cyanobacterias potencialmente produtoras de toxina; Aphanocapsa incerta, A. koordersii e Pseudanabaena galeata. Também verificou-se a presença de cianobactérias que produzem cheiro de geosmina e 2-metilisoborneol e a presença de algas que podem produzir odor e sabor na água como: Aulacoseira (odor de "gerânio" ou de “terra”), Cyclotella (gosto e odor de “peixe”), Chlamydomonas, Chlorella (odor de “mofo”), Dictyosphaerium (odor e sabor de “capim”), Scenedesmus e Staurastrum (odor de “capim”), Pediastrum (odor e sabor de “peixe”), Cryptomonas (gosto “doce” e odor de "violeta”), Mallomonas (odor de "violeta" e de "peixe”), Peridinium (odor de “pepino” ou de “peixe”) e Euglena (odor e sabor de “peixe”). Na análise quantitativa a densidade total da comunidade algácea está expressa em células/ml; a espécie mais encontrada na água é a Aphanocapsa incerta (2369 células/ml) que pertence a classe Cyanobacteria (Tabela 16). 
Tabela 15. Composição e tipo de organismo da comunidade fitoplâncton na amostra 2

\begin{tabular}{|c|c|c|}
\hline Táxons & $\begin{array}{c}\mathrm{N}^{\circ} \text { total de táxons por } \\
\text { classe }\end{array}$ & $\begin{array}{c}\% \text { de táxons por } \\
\text { classe }\end{array}$ \\
\hline CYANOBACTERIA (algas azuis) & 3 & 4 \\
\hline \multicolumn{3}{|l|}{ Aphanocapsa incerta } \\
\hline \multicolumn{3}{|l|}{ Aphanocapsa koordesii } \\
\hline \multicolumn{3}{|l|}{ Pseudoanabaena galeata } \\
\hline BACILLARIOPHYCEAE (diatomáceas) & 12 & 16,5 \\
\hline \multicolumn{3}{|l|}{ Aulacoseira ambigua } \\
\hline \multicolumn{3}{|l|}{ Aulacoseira distans } \\
\hline \multicolumn{3}{|l|}{ Aulacoseira sp } \\
\hline \multicolumn{3}{|l|}{ Brachysira vitrea } \\
\hline \multicolumn{3}{|l|}{ Cyclotella meneghiniana } \\
\hline \multicolumn{3}{|l|}{ Eunotia flexuosa } \\
\hline \multicolumn{3}{|l|}{ Frutulia rhomboides } \\
\hline \multicolumn{3}{|l|}{ Gomphonema sp } \\
\hline \multicolumn{3}{|l|}{ Navícula sp } \\
\hline \multicolumn{3}{|l|}{ Nitzschia palea } \\
\hline \multicolumn{3}{|l|}{ Pinnularia interrupta } \\
\hline \multicolumn{3}{|l|}{ Planothidium dubium } \\
\hline CHLOROPHYCEAE & 41 & 56 \\
\hline \multicolumn{3}{|l|}{ Actinastrum aciculare } \\
\hline \multicolumn{3}{|l|}{ Chlamydomonas angulosa } \\
\hline \multicolumn{3}{|l|}{ Cholorella minutissima } \\
\hline \multicolumn{3}{|l|}{ Chlorella vulgaris } \\
\hline \multicolumn{3}{|l|}{ Chlorococcum infusionum } \\
\hline \multicolumn{3}{|l|}{ Coccomyxa lacustris } \\
\hline Coelastrum astroideum & & \\
\hline Coelastrum proboscideum & & \\
\hline
\end{tabular}


Tabela 15. Composição e tipo de organismo da comunidade fitoplâncton na amostra 2

\begin{tabular}{ccc}
\hline Táxons & $\mathrm{N}^{\circ}$ total de táxons por \\
classe & $\begin{array}{c}\% \text { de táxons por } \\
\text { classe }\end{array}$
\end{tabular}

Coelastrum reticulatum

Coenocystis reniformis

Crucigenia quadrata

Crucigenia tetrapedia

Crucigeniella crucífera

Dictyosphaerium ehrenbergianum

Dictyosphaerium pulchellum

Dictyosphaerium tetrachotomum

Didymocystis fina

Eutetramorus fottii

Kircheriella aperta

Kircheriella lunaris

Kircheriella roselata

Monoraphidium arcuatum

Monoraphidium longiusculum

Monoraphidium tortile

Nephroclamys willeana

Ooscystis lacustris

Pediastrum duplex

Pediastrum tetras

Quadrigula closterioides

Scenedesmus acuminatus

Scenedesmus arcatus

Scenedesmus bicaudatus

Scenedesmus bijugus

Scenedesmus denticulatus 
Tabela 15. Composição e tipo de organismo da comunidade fitoplâncton na amostra 2

\begin{tabular}{|c|c|c|}
\hline Táxons & $\begin{array}{c}\mathrm{N}^{\circ} \text { total de táxons por } \\
\text { classe }\end{array}$ & $\begin{array}{c}\text { \% de táxons por } \\
\text { classe }\end{array}$ \\
\hline \multicolumn{3}{|l|}{ Scenedesmus opoliensis } \\
\hline \multicolumn{3}{|l|}{ Scenedesmus ovalternus } \\
\hline \multicolumn{3}{|l|}{ Scenedesmus quadricauda } \\
\hline \multicolumn{3}{|l|}{ Scenedesmus spinosus } \\
\hline \multicolumn{3}{|l|}{ Sphaerocystis schroeteri } \\
\hline \multicolumn{3}{|l|}{ Tetrastrum heterachantum } \\
\hline CHRYSOPHYCEAE & 1 & 1,5 \\
\hline \multicolumn{3}{|l|}{ Mallomonas sp } \\
\hline CRYPTOPHYCEAE & 2 & 2,5 \\
\hline \multicolumn{3}{|l|}{ Cryptomonas marsoonii } \\
\hline \multicolumn{3}{|c|}{ Pseudocryptomonas americana } \\
\hline DINOPHYCEAE & 1 & 1,5 \\
\hline \multicolumn{3}{|l|}{ Peridinium sp } \\
\hline EUGLENOPHYCEAE & 10 & 14 \\
\hline \multicolumn{3}{|l|}{ Euglena acus } \\
\hline \multicolumn{3}{|l|}{ Euglena sp } \\
\hline \multicolumn{3}{|l|}{ Lepocinclis fusiformes } \\
\hline \multicolumn{3}{|l|}{ Lepocinclis ovum } \\
\hline \multicolumn{3}{|c|}{ Lepocinclis ovum dimidio-minor } \\
\hline \multicolumn{3}{|l|}{ Lepocinclis salina } \\
\hline \multicolumn{3}{|l|}{ Phacus suecicus } \\
\hline \multicolumn{3}{|l|}{ Strombomonas sp } \\
\hline \multicolumn{3}{|l|}{ Trachelomonas curta } \\
\hline \multicolumn{3}{|l|}{ Trachelomonas oblonga } \\
\hline XANTHOPHYCEAE & 1 & 1,5 \\
\hline
\end{tabular}

Tetraplektron sp 
Tabela 15. Composição e tipo de organismo da comunidade fitoplâncton na amostra 2

\begin{tabular}{ccc}
\hline Táxons & $\begin{array}{c}\mathrm{N}^{\circ} \text { total de táxons por } \\
\text { classe }\end{array}$ & $\begin{array}{c}\% \text { de táxons por } \\
\text { classe }\end{array}$ \\
\hline ZYGNEMAPHYCEAE (desmídias) & 2 & 2,5 \\
Euastrum sp & & \\
Staurastrum volans & & \\
\hline
\end{tabular}

Tabela 16. Densidade do fitoplâncton (células/ml) na amostra 2

\begin{tabular}{cc}
\hline Táxons & Densidade (células/ml) \\
\hline Aphanocapsa incerta & 2369 \\
Crucigenia quadrata & 2031 \\
Scenedesmus ovalternus & 1760 \\
Crucigenia tetrapedia & 1489 \\
Coelastrum reticulatum & 1422 \\
Aulacoseira ambigua & 1083 \\
Didymocystis fina & 948 \\
Scenedesmus arcuatus & 914 \\
Scenedesmus quadricauda & 880 \\
Scenedesmus bicaudatus & 745 \\
Kirchneriella lunaris & 711 \\
Scenedesmus opoliensis & 677 \\
Pediastrum duplex & 305 \\
Scenedesmus denticulatus & 271 \\
Actinastrum aciculare & 203 \\
Chlorococcum infusionum & 203 \\
Chlorella minutissima & 169 \\
Chlorella vulgaris & 169 \\
Monoraphidium arcuatum & 169 \\
Nephrophidium willeana & 169 \\
\hline
\end{tabular}


Tabela 16. Densidade do fitoplâncton (células/ml) na amostra 2

\begin{tabular}{cc}
\hline Táxons & Densidade (células/ml) \\
\hline Monoraphidium tortile & 102 \\
Scenedesmus acuminatus & 135 \\
Sphaerocystis schroeteri & 135 \\
Monoraphidium longiusculum & 102 \\
Cyclotella meneghiniana & 68 \\
Navícula sp & 68 \\
Planothidium dubium & 68 \\
Scenedesmus bijugus & 68 \\
Trachelomonas volvocina & 68 \\
Chlamydomonas angulosa & 68 \\
Frustulia rhomboides & 34 \\
Nitzschia palea & 34 \\
Oocystis lacustris & 34 \\
Pinnularia interrupta & 34 \\
Trachelomonas curta & 34 \\
Trachelomonas oblonga & 34 \\
\hline
\end{tabular}

Na análise qualitativa da $3^{\mathrm{a}}$ amostra foram identificados 65 táxons distribuídos em 6 classes (Tabela 17). Verificou-se também a presença de cyanobacteria produtora de microcistina (hepatotoxina) Aphanocapsa cumulus e de algumas espécies de cyanobacteria potencialmente produtoras de toxina; Aphanocapsa incerta, Epigloeosphaera brasilica e Merismopedia tenuissima. Na água de cultivo também verificou-se a presença de cianobactérias que produzem cheiro de geosmina e 2metilisoborneol e a presença de algas que podem produzir odor e sabor na água como: Aulacoseira (odor de "gerânio" ou de “terra”), Cyclotella (gosto e odor de "peixe”), Synedra (odor e sabor de "capim” ou de "mofo") Chlamydomonas, Chlorella (odor de “mofo”), Dictyosphaerium (odor e sabor de “capim”), Scenedesmus e Staurastrum (odor de “capim”), Pediastrum (odor e sabor de "peixe”) e Euglena (odor e sabor de 
“peixe”). Na análise quantitativa a densidade total da comunidade algácea está expressa em células/ml; a espécie mais encontrada na água é a Aulacoseira ambigua (4773 células/ml) que pertence a classe Bacillariophyceae (Tabela 18).

Tabela 17. Composição e tipo de organismo da comunidade fitoplâncton na amostra 3

\begin{tabular}{ccc}
\hline Táxons & $\begin{array}{c}\mathrm{N}^{\circ} \text { total de táxons por } \\
\text { classe }\end{array}$ & $\begin{array}{c}\text { \% de táxons por } \\
\text { classe }\end{array}$ \\
\hline CYANOBACTERIA (algas azuis) & 4 & 6 \\
Aphanocapsa cumulus & & \\
Aphanocapsa incerta & 18,5 \\
Epigloeosphaera brasilica & & \\
Merismopedia tenuissima & & \\
BACILLARIOPHYCEAE (diatomáceas) & & \\
Amphora sp & & \\
Aulacoseira ambigua & & \\
Aulacoseira distans & & \\
Aulacoseira sp & & \\
Cyclotella meneghiniana & & \\
Cymbella & & \\
Eunotia flexuosa & & \\
Gomphonema sp \\
Navícula sp \\
Pinnularia interrupta \\
Planothidium dubium \\
Synedra ulna \\
AcHLOROPHYCEAE \\
Ankistrodesmus gracillis \\
Chlamydomonas angulosa
\end{tabular}


Tabela 17. Composição e tipo de organismo da comunidade fitoplâncton na amostra 3

\begin{tabular}{ccc}
\hline Táxons & $\begin{array}{c}\mathrm{N}^{\circ} \text { total de táxons por } \\
\text { classe }\end{array}$ & $\begin{array}{c}\% \text { de táxons por } \\
\text { classe }\end{array}$ \\
\hline
\end{tabular}

Chlorella vulgaris

Chlorococcum infusionum

Coccomyxa lacustris

Coelastrum cambricum

Coelastrum microporum

Coelastrum proboscideum

Coelastrum reticulatum

Crucigenia quadrata

Crucigenia tetrapedia

Crucigeniella crucífera

Dictyosphaerium ehrenbergianum

Dictyosphaerium elegans

Dictyosphaerium tetrachotomum

Didymocystis fina

Elakatothirix genevensis

Kircheriella lunaris

Kircheriella roselata

Monoraphidium arcuatum

Monoraphidium contortum

Monoraphidium longiusculum

Monoraphidium tortile

Nephroclamys willeana

Ooscystis lacustris

Pediastrum duplex

Scenedesmus acuminatus

Scenedesmus arcuatus 
Tabela 17. Composição e tipo de organismo da comunidade fitoplâncton na amostra 3

\begin{tabular}{|c|c|c|}
\hline Táxons & $\begin{array}{c}\mathrm{N}^{\circ} \text { total de táxons por } \\
\text { classe }\end{array}$ & $\begin{array}{c}\text { \% de táxons por } \\
\text { classe }\end{array}$ \\
\hline \multicolumn{3}{|l|}{ Scenedesmus bicaudatus } \\
\hline \multicolumn{3}{|l|}{ Scenedesmus denticulatus } \\
\hline \multicolumn{3}{|l|}{ Scenedesmus opoliensis } \\
\hline \multicolumn{3}{|l|}{ Scenedesmus ovalternus } \\
\hline \multicolumn{3}{|l|}{ Scenedesmus quadricauda } \\
\hline \multicolumn{3}{|l|}{ Scenedesmus spinosus } \\
\hline \multicolumn{3}{|l|}{ Tetrastrum heterachantum } \\
\hline \multicolumn{3}{|l|}{ Tetrastrum peterfii } \\
\hline EUGLENOPHYCEAE & 6 & 9 \\
\hline \multicolumn{3}{|l|}{ Euglena acus } \\
\hline \multicolumn{3}{|l|}{ Euglena sp } \\
\hline \multicolumn{3}{|l|}{ Lepocinclis ovum } \\
\hline \multicolumn{3}{|l|}{ Strombomonas sp } \\
\hline \multicolumn{3}{|l|}{ Trachelomonas oblonga } \\
\hline \multicolumn{3}{|l|}{ Trachelomonas volvocina } \\
\hline XANTHOPHYCEAE & 4 & 6 \\
\hline \multicolumn{3}{|l|}{ Tetraedriella jovetti } \\
\hline \multicolumn{3}{|l|}{ Tetraedriella sp } \\
\hline \multicolumn{3}{|l|}{ Tetraplektron deniseae } \\
\hline \multicolumn{3}{|l|}{ Tetraplektron sp } \\
\hline ZYGNEMAPHYCEAE (desmídias) & 3 & 5 \\
\hline \multicolumn{3}{|l|}{ Staurastrum volans } \\
\hline \multicolumn{3}{|l|}{ Staurastrum sp } \\
\hline Staurodesmus sp & & \\
\hline
\end{tabular}


Tabela 18. Densidade do fitoplâncton (células/ml) na amostra 3

\begin{tabular}{|c|c|}
\hline Táxons & Densidade (células/ml) \\
\hline Aulacoseira ambigua & 4773 \\
\hline Aphanocapsa incerta & 3046 \\
\hline Crucigenia quadrata & 1625 \\
\hline Aphanocapsa cumulus & 1219 \\
\hline Didymocystis fina & 1083 \\
\hline Scenedesmus ovalternus & 1083 \\
\hline Coccomyxa lacustris & 812 \\
\hline Scenedesmus opoliensis & 406 \\
\hline Scenedesmus acuminatus & 271 \\
\hline Scenedesmus bicaudatus & 271 \\
\hline Tetrastrum heteracanthum & 271 \\
\hline Chlorella vulgaris & 135 \\
\hline Crucigenia tetrapedia & 135 \\
\hline Monoraphidium arcuatum & 135 \\
\hline Navícula sp & 135 \\
\hline Planothidium dubium & 135 \\
\hline Scenedesmus quadricauda & 135 \\
\hline Chlorococcum infusionum & 102 \\
\hline Aulacoseira sp & 68 \\
\hline Chlamydomonas angulosa & 68 \\
\hline Kirchneriella lunaris & 68 \\
\hline Monoraphidium tortile & 68 \\
\hline Pinnularia iterrupta & 68 \\
\hline Staurodesmus sp & 68 \\
\hline Amphora sp & 34 \\
\hline Cyclotella meneghiniana & 34 \\
\hline
\end{tabular}


Tabela 18. Densidade do fitoplâncton (células/ml) na amostra 3

\begin{tabular}{cc}
\hline Táxons & Densidade (células/ml) \\
\hline Cymbella sp & 34 \\
Eunotia flexuosa & 34 \\
Monoraphidium longiusculum & 34 \\
Oocystis lacustris & 34 \\
Staurastrum sp & 34 \\
Tetradiella jovetti & 34 \\
Trachelomonas volvocina & 34 \\
\hline
\end{tabular}

Na análise qualitativa da água de depuração foram identificados 58 táxons distribuídos em 6 classes (Tabela 19). Verificou-se também a presença de cyanobacteria produtora de microcistina (hepatotoxina) Aphanocapsa cumulus e de algumas espécies de cyanobacteria potencialmente produtoras de toxina; Chroococcus minutus. Verificou-se também a presença de algas que podem produzir odor e sabor na água como: Aulacoseira (odor de "gerânio” ou de “terra”), Cyclotella (gosto e odor de “peixe”), Chlamydomonas, Chlorella (odor de “mofo”), Dictyosphaerium (odor e sabor de “capim”), Scenedesmus (odor de “capim”), Pediastrum (odor e sabor de “peixe”), Cryptomonas (gosto “doce” e odor de “violeta”) e Euglena (odor e sabor de “peixe”). $\mathrm{Na}$ análise quantitativa a densidade total da comunidade algácea está expressa em células/ml; a espécie mais encontrada na água é a Scenedesmus opoliensis (6770 células/ml) que pertence a classe Chlorophyceae (Tabela 20). 
Tabela 19. Composição e tipo de organismo da comunidade fitoplâncton na água de depuração

\begin{tabular}{ccc}
\hline Táxons & $\begin{array}{c}\mathrm{N}^{\circ} \text { total de táxons por } \\
\text { classe }\end{array}$ & $\begin{array}{c}\% \text { de táxons por } \\
\text { classe }\end{array}$ \\
\hline
\end{tabular}

CYANOBACTERIA (algas azuis)

2

3

Aphanocapsa cumulus

Chroococcus minutus

BACILLARIOPHYCEAE (diatomáceas)

Aulacoseira distans

Cyclotella meneghiniana

Nitzschia palea

CHLOROPHYCEAE

46

79

Actinastrum aciculare

Ankistrodesmus bibraianus

Ankistrodesmus gracillis

Chlamydomonas angulosa

Chlorella minutissima

Chlorella vulgaris

Chlorococcum infusionum

Choricystis cylindracea

Coelastrum astroideum

Coelastrum cambricum

Coelastrum reticulatum

Coenochloris planoconvexa

Coenocystis reniformis

Crucigenia quadrata

Crucigeniella crucífera

Dictyosphaerium ehrenbergianum

Dictyosphaerium pulchellum 
Tabela 19. Composição e tipo de organismo da comunidade fitoplâncton na água de depuração

Táxons $\mathrm{N}^{\circ}$ total de táxons por \% de táxons por classe classe

Dictyosphaerium tetrachotomum

Didymocystis fina

Didymocystis plantonica

Eutetramorus planctonicus

Kircheriella contorta

Kircheriella lunaris

Kircheriella roselata

Monoraphidium arcuatum

Monoraphidium circinale

Monoraphidium contortum

Monoraphidium minutum

Monoraphidium nanum

Ooscystis lacustris

Pediastrum duplex

Radiococcus nimbatus

Scenedesmus acuminatus

Scenedesmus acutus

Scenedesmus arcuatus

Scenedesmus bicaudatus

Scenedesmus bijugus

Scenedesmus ecornis

Scenedesmus intermedius

Scenedesmus opoliensis

Scenedesmus ovalternus

Scenedesmus quadricauda 
Tabela 19. Composição e tipo de organismo da comunidade fitoplâncton na água de depuração

\begin{tabular}{ccc} 
Táxons & $\begin{array}{c}\mathrm{N}^{\circ} \text { total de táxons por } \\
\text { classe }\end{array}$ & $\begin{array}{c}\text { \% de táxons por } \\
\text { classe }\end{array}$ \\
\hline $\begin{array}{c}\text { Scenedesmus spinosus } \\
\text { Schroederia indica } \\
\text { Sphaerocystis schroeteri } \\
\text { Tetrastrum peterfii } \\
\text { CRYPTOPHYCEA }\end{array}$ & 2 \\
Cryptomonas sp & 1 & \\
EUGLENOPHYCEAE & 4 & \\
Euglena acus & & \\
Lepocinclis fusiformes & & \\
Lepocinclis ovum & & \\
Strombomonas sp & & 2 \\
Trachelomonas volvocinopsis & & \\
XANTHOPHYCEAE & 1 & 2 \\
Tetraplektron sp & & \\
ZYGNEMAPHYCEAE (desmídias) & & \\
Mougeotia sp & & \\
\hline
\end{tabular}

Tabela 20. Densidade do fitoplâncton (células/ml) na água de depuração

\begin{tabular}{cc}
\hline Táxons & Densidade (células/ml) \\
\hline Scenedesmus opoliensis & 6770 \\
Choricystis cylindracea & 2606 \\
Scenedesmus quadricauda & 1455 \\
Tretrastrum peterfii & 1151 \\
Dictyosphaerium ehrenbergianum & 1117 \\
Scenedesmus acuminatus & 745
\end{tabular}


Tabela 20. Densidade do fitoplâncton (células/ml) na água de depuração

\begin{tabular}{cc}
\hline Táxons & Densidade (células/ml) \\
\hline Didymocystis fina & 643 \\
Didymocystis planctonica & 542 \\
Kirchneriella lunaris & 542 \\
Sphaerocystis schroeteri & 542 \\
Chlorella vulgaris & 508 \\
Crucigenia quadrata & 474 \\
Scenedesmus bijugus & 474 \\
Radiococcus nimbatus & 440 \\
Chlorella minutissima & 406 \\
Monoraphidium nanum & 305 \\
Coelastrum astroideum & 271 \\
Chlamydomonas angulosa & 237 \\
Cyclotella meneghiniana & 237 \\
Chlorococcum infusionum & 203 \\
Monoraphidium arcuatum & 203 \\
Scenedesmus bicaudatus & 203 \\
Scenedesmus arcuatus & 203 \\
Chroococcus minutus & 135 \\
Monoraphidium circinale & 135 \\
Scenedesmus ovalternus & 135 \\
Monoraphidium contortum & 135 \\
Monoraphidium minutum & 68 \\
Schroederia indica & \\
\hline
\end{tabular}

A composição das comunidades fitoplanctônicas é muito variada nos ambientes e tem como característica refletir toda e qualquer alteração ambiental sofrida (Margalef,1983). 
Os táxons identificados na água de cultivo nas três amostras indicam riqueza considerável de espécies, sendo que a classe Chlorophyceae contribuiu com mais ou menos $50 \%$ do total de táxons. Tais resultados corroboram com os vários estudos realizados sobre a classe (Xavier, 1981; Xavier et al, 1985; Sant'Anna et al, 1988; Sant'Anna et al, 1989; Moura, 1996; Sant'Anna et al, 1997; Matsuzaki, 2002).

A classe Cyanophyceae foi a quarta classe em número de táxons contribuindo com, aproximadamente, $14 \%$ do total de táxons. As cianofíceas são freqüentemente encontradas em ambientes ricos em matéria orgânica (Gentil, 2000).

As cianobactérias ou cianofíceas durante o seu ciclo de vida produzem inúmeros compostos voláteis e não voláteis que, não podendo ser utilizados imediatamente ou armazenados para uso futuro, são liberados para a fase líquida. Do ponto de vista microbiológico, as cianobactérias ou algas azuis são microorganismos unicelulares procariontes e, deste modo, podem ser considerados como bactérias, no entanto, por serem fotossintetizantes também são consideradas como algas (Atlas \& Bartha, 1987). A variedade de compostos extracelulares liberados pelas cianobactérias é, significativamente, grande e, dentre estes, alguns podem causar problemas de gosto e odor diretamente e indiretamente, além de apresentarem toxicidade aguda e crônica (Repavich et al, 1990).

Segundo Kubtiza (2000) a ocorrência de off flavor é mais freqüente em peixes cultivados intensivamente em viveiros, onde os altos níveis de arraçoamento, e conseqüente acúmulo de nutrientes favorece a intensa proliferação de algas cianofíceas e fungos actinomicetos. Estes organismos são responsáveis pela produção de GEO, associadas ao sabor ou odor de "terra” ou de "barro”, e MIB, responsável pelo sabor ou odor de "mofo" em peixes de piscicultura. Peixes cultivados em "raceways" ou tanques-rede também podem apresentar off flavor, dependendo da qualidade da água neste sistema de produção. Maus sabores causados pela absorção de GEO e MIB são os mais predominantes em piscicultura intensiva.

Na água de cultivo verificamos um grande número de táxons o que implica em um ambiente eutrófico. Nas três amostras analisadas um número alto de cianobactérias foi encontrado ( $8 \%, 13 \%$ e $23 \%$ respectivamente) o que pode ocasionar em odor e sabor 
desagradáveis na água e conseqüentemente no pescado. No tanque de depuração podemos verificar um número menor de táxons encontrados na água, o que já era esperado, pois durante todo o trabalho, no tanque ocorria uma entrada e saída de água e esta era sempre limpa.

Através das análises qualitativas e quantitativas realizadas conseguimos distinguir a água de cultivo da água de depuração onde uma apresentou um número muito maior de algas do que a outra. Podemos também verificar que a água de cultivo apresentou um grande número de cianobactérias o que seria a principal causa do odor e sabor desagradáveis e, conseqüentemente, off flavor no pescado.

\subsection{Conclusões}

A água do tanque de cultivo apresentou problemas de eutrofização e presença de geosmina, condições que resultam em problemas de off flavor no pescado.

Tanto a água do tanque de cultivo como a de depuração apresentaram condições microbiológicas adequadas em relação à legislação.

Através da análise qualitativa e quantitativa de algas e cianobactérias verificou-se que a água do tanque de cultivo apresenta concentrações altas de cianobactérias que causam odor e sabor de "barro" na água. 


\section{DETERMINAÇÃO DO OFF FLAVOR EM TILÁPIA DO NILO (Oreochromis niloticus) E O SEU CONTROLE ATRAVÉS DA DEPURAÇÃO.}

\section{Resumo}

Este estudo teve por objetivo a detecção de off flavor em tilápia do Nilo e posterior depuração para eliminação deste. Os peixes submetidos à depuração e o controle foram comparados entre si para posterior escolha do melhor tempo para depuração; estes, não apresentaram diferenças significativas $(\mathrm{p}>0,05)$ para composição centesimal, nitrogênio não protéico - NNP, bases nitrogenadas voláteis totais - BNVT e pH nos tempos de depuração. O processo de depuração provocou perda de peso mais intensa nos três primeiros dias de depuração. Através das análises sensoriais verificouse que os peixes, que corresponderam ao controle, apresentaram maior intensidade de off flavor quando comparados aos demais. A depuração por 3 dias para o atributo odor apresentou eficiência semelhante, estatisticamente (Teste F), ao tratamento por 5 dias porém, foi considerada diferente do tratamento por 7 dias. Para o atributo sabor os tratamentos de 3, 5 e 7 dias não diferiram, estatisticamente, entre si. O processo de depuração permitiu bons resultados quanto a eliminação de off flavor da tilápia, pois, através das análises realizadas, pode-se aferir o tempo ideal de 5 dias de depuração conduzida em um tanque com água corrente e limpa.

\section{Summary}

The objective of this study was to the detect of off flavor in Nile Tilapia and its subsequent elimination through depuration. The fish submitted to depuration and the control group were compared for later choice of the best depuration time. They did not present significant differences $(\mathrm{p}>0.05)$ as to centesimal composition, non-protein 
nitrogen - NPN, total volatile nitrogenous bases -TVB-N, and $\mathrm{pH}$ in the depuration periods. The depuration process provoked a more intense weight loss in the three first depuration periods. Through sensory analyses, we verified that the fish which corresponded to the control presented higher off-flavor intensity when compared to the others. As to odor, the 3-day depuration was statistically (F Test) similar in efficiency to the 5-day treatment. However, it was considered different from the 7-day treatment. As to flavor, the treatments of 3,5 , and 7 days did not differ statistically. The depuration process allowed for good results as to the elimination of the off-flavor in tilapia, for, through the analyses carried out, we could determine 5 days as the ideal depuration period to be conducted in a tank with clean running water.

\subsection{Introdução}

O sabor característico e desejável do pescado pode ser alterado antes ou após a despesca. Geralmente, problemas de sabor que ocorrem após a despesca são resultantes da oxidação de gorduras ou ação de microrganismos específicos que ocorrem em função da estocagem inadequada ou prolongada do pescado. Problemas de alterações do sabor que se desenvolvem durante o cultivo podem estar relacionado a dieta fornecida ou, ainda mais comumente, a desequilíbrios ambientais do cultivo (Tucker \& Ploeg, 1999). Peixes cujos sabores são rejeitados pelos consumidores são denominados off flavor.

Lovshin (1997) relata que a tilápia adquiri off flavor proveniente de algas azuis-verdes e outros microrganismos, assim, para assegurar a qualidade do peixe, a tilápia deve ser mantida em água limpa por três a cinco dias para sofrer a depuração do off flavor.

Ayroza (1995) orienta a despesca de peixes cultivados com depuração que pode ser feita no próprio viveiro de cultivo, através do corte do fornecimento de qualquer tipo de alimentação de três a cinco dias antes da despesca, ou através de depuração em tanques de alvenaria; neste caso realiza-se a despesca total do viveiro, colocando-se todos os peixes no tanque de alvenaria construído para esta finalidade, com bastante renovação de água, permanecendo em média por 48 horas. 
Neste trabalho foi abordado um tipo específico de off flavor que se desenvolve durante o cultivo e é resultante da proliferação de microrganismos sintetizadores da Geosmina (GEO) e 2-metilisoborneol (MIB), compostos que conferem ao peixe um sabor de "terra" e de "mofo", e que ocorrem geralmente em, cultivos eutrofizados, sob condições limnológicas específicas.

\subsection{Material e métodos}

\subsubsection{Procedimento de depuração}

Foram utilizados peixes provenientes de criatório da região de Artur Nogueira-SP, da espécie tilápia do Nilo, Oreochromis niloticus. Os peixes foram capturados em tanques-terra e transportados em tanques com aeração para o Setor de Piscicultura do Departamento de Zootecnia da ESALQ - USP. Em seguida, foram submetidos a depuração em tanque com água corrente, proveniente de poço artesiano, onde permaneceram por 3, 5 e 7 dias, sem alimentação. Foram colocados, aproximadamente, 32peixes $/ \mathrm{m}^{3}$ no tanque de depuração.

\subsubsection{Procedimento para coleta das amostras}

Foram realizadas três coletas (blocos), cada coleta era composta de peixes que não sofreram depuração (controle) e peixes que sofreram depuração por 3, 5 e 7 dias. Após este período, os peixes foram colocados, ainda vivos, diretamente em caixas de isopor, em camadas intercaladas com gelo, preparado com água potável, onde sofreram o choque térmico. Os peixes, em situação de hipotermia, foram transportados ao Setor de Processamento de Alimentos do Departamento de Agroindústria, Alimentos e Nutrição da ESALQ - USP.

\subsubsection{Determinação da perda de peso}

Os peixes foram pesados em lotes, para cada dia de depuração, antes e depois da depuração para verificação da perda de peso nos quatro períodos experimentais e os resultados foram expressos em porcentagem. 


\subsubsection{Preparo do pescado para análises e processamento}

Os peixes foram eviscerados, descabeçados, a pele retirada, lavados em água corrente, filetados e, imediatamente, colocados em bandejas com gelo. Estas operações foram conduzidas por operadores munidos de luvas, em mesa processadora com utensílios de plástico rígido, para apoio e de aço inoxidável, para corte. Depois seguiram para as análises microbiológicas e físico-químicas. Para a realização da análise sensorial os filés foram mantidos a $-18^{\circ} \mathrm{C}$ por, no máximo, 10 dias e submetidos às análises microbiológicas, antes da degustação.

\subsubsection{Análises microbiológicas}

As análises microbiológicas foram realizadas nos três blocos e foram conduzidas em triplicata para cada bloco. No $1^{\underline{0}}$ bloco, a análise microbiológica foi feita no pescado recém capturado, sem depuração, e no pescado congelado (antes da realização da análise sensorial). No $2^{0}$ bloco, a análise microbiológica foi realizada no pescado depurado por 3 dias e no pescado congelado (depurado). No $3^{\underline{0}}$ bloco, a análise microbiológica foi realizada no pescado depurado por 7 dias e no pescado congelado (depurado). As metodologias utilizadas para as análises convencionais seguiram as recomendações de Vanderzant \& Splittstoesser (1992) e Silva et al. (1997). O preparo das amostras foi feito pela técnica da enxaguadura, onde $100 \mathrm{~g}$ de filés de tilápia, com espessura de, aproximadamente, $0,5 \mathrm{~cm}$ foram misturados com $100 \mathrm{~mL}$ de água peptonada tamponada (1:1) e submetidos a agitação manual vigorosa por 50 vezes. Para efeito de diluição, $1 \mathrm{~mL}$ pipetado desta enxaguadura correspondia a $1 \mathrm{~g}$ de peixe. As diluições $10^{-1}$ a $10^{-4}$ foram preparadas diluindo-se $10 \mathrm{~mL}$ da amostra em $90 \mathrm{~mL}$ de água peptonada, 0,1\% e esterilizada. Os microrganismos analisados foram:

\subsubsection{Coliformes totais e coliformes fecais}

Utilizou-se a técnica de tubos múltiplos, série de 5 tubos, para a estimativa do Número Mais Provável (NMP). Para a prova presuntiva, inoculou-se $10 \mathrm{~mL}$ da diluição $10^{-2}$ nos 5 tubos contendo Caldo Lauril Sulfato de Sódio em concentração dupla. Inoculou-se volumes de $1 \mathrm{~mL}$ da diluição $10^{-2}$ em uma série de 5 tubos contendo Caldo 
Lauril Sulfato de Sódio em concentração simples, e volumes de $1 \mathrm{~mL}$ da diluição $10^{-3}$, em outra série de 5 tubos contendo o mesmo meio. Incubaram-se os tubos a $36^{\circ} \mathrm{C} \pm$ $1^{\circ} \mathrm{C}$, por 48 horas. A positividade foi indicada pelo crescimento e presença de gás nos tubos de Duhram. Para a confirmação de coliformes totais, repicou-se os tubos positivos do Caldo Lauril Sulfato de Sódio para tubos de Caldo Verde Brilhante Bile 2\% lactose, que foram incubados a $36^{\circ} \mathrm{C} \pm 1^{\circ} \mathrm{C}$, por $48 \mathrm{~h}$. Para a prova confirmatória de coliformes fecais, repicou-se os tubos positivos do Caldo Lauril Sulfato de Sódio para tubos de caldo EC, incubando-os a $45^{\circ} \mathrm{C} \pm 0,2^{\circ} \mathrm{C}$, por $48 \mathrm{~h}$, em banho-maria, com agitação. A presença de gás indica positividade do tubo para a presença de coliformes totais (CVBLB 2\%) e de coliformes fecais (EC). Através da combinação do número de tubos positivos, em cada série de diluição, nos testes para coliformes totais e fecais, e consultando-se a Tabela de Número Mais Provável, obteve-se NMP de coliformes totais/g de amostra e coliformes fecais/g (APHA, 1998; Hitchins et al., 2004).

\subsubsection{Salmonella spp.}

Para a detecção presuntiva de Salmonella, utilizou-se o kit 1-2 Salmonella (Aprovado pela Association of Official Analytical Chemistis - AOAC em 2000). Foi realizado um pré-enriquecimento de cada amostra analisada, inoculando-se 25 g de pescado em um erlenmeyer contendo $225 \mathrm{~mL}$ de caldo lactosado. Os frascos foram incubados a temperatura de $37^{\circ} \mathrm{C}$, por $24 \mathrm{~h}$. Após o período de incubação, transferiu-se 0,1 mL da amostra pré-enriquecida para o kit, incubando-o a $35^{\circ} \mathrm{C}$, por $14-30 \mathrm{~h}$.

\subsubsection{Staphylococcus coagulase positiva}

Para a análise de $S$. Coagulase positiva foram utilizadas placas com meio Agar Baird-Parker (BPA), através do espalhamento do inóculo na superfície, com a alça de Drigalsky. Da diluição $10^{-1}$ espalhou-se $0,1 \mathrm{~mL}$ em duas placas com o meio; o mesmo procedimento foi adotado para a diluição $10^{-2}$ e para a diluição $10^{-3}$. Após a absorção do inóculo, as placas foram invertidas e incubadas a $35-37^{\circ} \mathrm{C}$ por $24-48 \mathrm{~h}$. Após este período, procedeu-se a contagem das colônias típicas (pretas, pequenas, lisas e com 
halo). Para a confirmação das colônias típicas foram realizados coloração de Gram e provas de catalase e coagulase.

\subsubsection{Contagem total de mesófilos aeróbios}

Para esta análise, utilizou-se a técnica do plaqueamento em profundidade, pipetando-se em duplicata $1 \mathrm{ml}$ das diluições $10^{-2}, 10^{-3}$ e $10^{-4}$. O meio de cultivo utilizado foi o Plate Count Agar (PCA) com incubação a $35^{\circ} \mathrm{C} / 24-48 \mathrm{~h}$. Após a incubação, procedeu-se a contagem das UFC, para expressão do resultado como UFC/g.

\subsubsection{Análises físico-químicas}

As análises físico-químicas estão descritas a seguir:

4.2.6.1 Umidade: determinada por gravimetria, de acordo com AOAC (1995).

4.2.6.2 Proteína bruta: mediante a determinação do nitrogênio total, pelo método Kjeldahl, de acordo com AOAC (1995).

4.2.6.3 Lipídeos: determinados através do método de Soxhlet, utilizando hexano como solvente, conforme descrito pela AOAC (1995).

4.2.6.4 Cinza: por incineração da matéria orgânica, de acordo com AOAC (1995).

\subsubsection{Nitrogênio não protéico (NNP)}

Determinado por precipitação das proteínas musculares com ácido tricloroacético (TCA), seguida de avaliação do nitrogênio não protéico presente no extrato TCA, através do método Micro Kjeldhal, de acordo com AOAC (1995).

\subsubsection{Bases nitrogenadas voláteis totais (BNVT)}

Determinadas por meio de precipitação protéica com ácido tricloroacético (TCA), e destilação de alíquotas de $20 \mathrm{~mL}$ do filtrado; recebimento do destilado em 
ácido bórico, a 1\%, com indicador misto e titulação com ácido clorídrico, 0,02 N, conforme descrito por Morga (1975).

\subsubsection{Determinação de $\mathrm{pH}$}

Determinado em potenciômetro digital Digimed, utilizando o músculo homogeneizado em água destilada, na proporção 1:1.

\subsubsection{Análise sensorial}

\subsubsection{Seleção preliminar dos provadores}

Inicialmente foi realizada uma pré-seleção com 20 pessoas que costumam consumir peixes. Utilizou-se o teste de comparação pareada onde cada provador recebeu 2 amostras de peixe, uma com nenhum off flavor (peixes depurados por 7 dias) e a outra com muito off flavor (peixes que não sofreram depuração). Os provadores foram solicitados a provarem as amostras da esquerda para a direita (aleatoriamente) e identificarem qual amostra possui maior intensidade de off flavor. Foram realizadas 5 sessões consecutivas por 5 dias. O critério usado para a seleção de provadores foi no mínimo de $60 \%$ de acertos no total de testes realizados.

\subsubsection{Levantamento de atributos}

Foram realizadas 2 sessões e em cada sessão foi apresentada duas amostras de peixe, uma com nenhum off flavor e outra com muito off flavor, solicitando-se que o provador anotasse as similaridades e as diferenças entre os peixes.

\subsubsection{Elaboração das fichas individuais}

Após as sessões de levantamento de termos e discussão individual com os provadores foram montadas as listas de atributos de cada provador. Com as listas de atributos de cada provador foram então elaboradas as fichas com escalas de intensidade. Foram empregadas mais 2 sessões para testar as fichas, já simulando o teste definitivo. 


\subsubsection{Procedimento para análise sensorial}

Foi utilizada uma equipe de 10 provadores treinados, previamente, quando foram definidas escalas para avaliação do aroma e sabor dos peixes. Para a medida da intensidade dos atributos (odor e sabor), foi utilizada uma escala estruturada numérica variando de muito off flavor (nota 9) a nenhum off flavor (nota 1). As amostras foram apresentadas aos provadores em pratos de cerâmica, codificados, com números de 3 dígitos, selecionados aleatoriamente. Os peixes in natura depurados (3, 5 e 7 dias) e os não depurados (controle) foram servidos aos provadores para análise de odor e sabor; para a análise de sabor, o pescado foi cortado em pedaços de $4 \mathrm{~cm}^{2}$, embrulhado em folha de papel encerado, submetido à cocção em microondas, por 40 seg, e servido aos provadores. Para as análises de odor, o pescado foi servido cru.

\subsubsection{Análise estatística}

O delineamento experimental adotado foi o de blocos casualizados, com 4 tratamentos e 3 blocos, sendo cada época de coleta um bloco. Os dados obtidos foram submetidos ao teste $\mathrm{F}$ da análise de variância (PROC GLM) através do programa Statistical Analysis System (SAS, 1999) e posteriormente as médias foram comparadas pelo teste de Tukey, a 5\% de probabilidade.

Os dados relativos às análises microbiológicas não foram comparados estatisticamente por terem sido utilizados neste estudo somente para garantir um produto adequado ao consumo pelos provadores.

\subsection{Resultados e discussão}

\subsubsection{Perda de Peso}

A perda de peso dos peixes não foi constante ocorrendo diferença estatística entre os dias de depuração (Tabela 1). A perda de peso dos animais após 3, 5 e 7 dias de depuração foi diferente, significativamente, da perda de peso dos peixes que não sofreram depuração (controle). Já o peso dos peixes após 3 dias de depuração diferiu, significativamente, dos peixes que sofreram depuração de 5 e 7 dias, mas estes não 
diferem entre si. O processo de depuração provocou perda de peso mais intensa nos três primeiros dias de depuração.

Tabela 1. Perda de Peso (\%) de tilápias submetidas à depuração de 3, 5 e 7 dias e no controle

\begin{tabular}{cc}
\hline Depuração (dias) & Perda de Peso (\%) \\
\hline Controle & $0^{\mathrm{A}} \pm 0$ \\
3 & $6,72^{\mathrm{B}} \pm 0,28$ \\
5 & $8,56^{\mathrm{C}} \pm 0,37$ \\
7 & $8,68^{\mathrm{C}} \pm 0,05$ \\
\hline
\end{tabular}

Médias seguidas pela mesma letra não diferem pelo teste de Tukey a 5\%; CV=0,39\%

Lovell (1974), sugere o processo de depuração para a eliminação de off flavor em bagres do canal (Pimelodus sp), mas alerta para a significativa perda de peso, em função da não alimentação, durante o processo que pode chegar a 12\% do peso inicial. Em seu estudo, o autor registrou perda de peso de 5\% em peixes, com 3 dias de depuração e de 7\% em peixes com 6 dias de depuração.

Segundo Kubitza (1999), períodos prolongados de depuração, sem que haja alimentação dos peixes, podem resultar em significativa perda de peso. Sob temperaturas de 22 a $24^{\circ} \mathrm{C}$ o "catfish" (Pimelodus sp) perdeu entre 10 e $17 \%$ de peso comparado a 8 a $9 \%$, a $16^{\circ} \mathrm{C}$.

\subsubsection{Análises microbiológicas}

A Resolução RDC n 12, de 2 de janeiro de 2001 da Agência Nacional de Vigilância Sanitária (BRASIL, 2004c), apresenta padrão para coliformes de, no máximo de $10^{2} \mathrm{NMP} / \mathrm{g}$, para pescado in natura ou congelado. Observou-se, neste trabalho, que todos os valores encontrados para coliformes, no pescado in natura e no congelado, estão abaixo dos limites estabelecidos pela legislação (Tabelas 2 e 3). A mesma resolução, também, apresenta padrão para Staphylococcus de, no máximo, $10^{3}$ UFC/g e para Salmonella ausência em $25 \mathrm{~g}$, tanto para o pescado in natura como para o 
pescado congelado. Através das Tabelas 5 e 6 pode-se observar que todos os valores encontrados para Staphylococcus e Salmonella estão de acordo com a legislação.

Tabela 2. Coliformes totais, Coliformes fecais, Staphylococcus, Salmonella e Mesófilos em filés de tilápia submetidos à depuração e no controle

\begin{tabular}{cccccc}
\hline $\begin{array}{c}\text { Depuração } \\
\text { (Dias) }\end{array}$ & $\begin{array}{c}\text { Coliformes } \\
\text { Totais }\end{array}$ & $\begin{array}{c}\text { Coliformes } \\
\text { Fecais }\end{array}$ & Staphylococcus & Salmonella & Mesófilos \\
\hline Controle & $1,1 \mathrm{NMP} / \mathrm{g}$ & $0,7 \mathrm{NMP} / \mathrm{g}$ & $<10^{2} \mathrm{UFC} / \mathrm{g}$ & Ausência/25g & $2,3 \times 10^{3} \mathrm{UFC} / \mathrm{g}$ \\
3 & $4,7 \mathrm{NMP} / \mathrm{g}$ & $1,1 \mathrm{NMP} / \mathrm{g}$ & $<10^{2} \mathrm{UFC} / \mathrm{g}$ & Ausência/25g & $1,6 \times 10^{4} \mathrm{UFC} / \mathrm{g}$ \\
7 & $1,7 \times 10 \mathrm{NMP} / \mathrm{g}$ & $1,4 \mathrm{NMP} / \mathrm{g}$ & $<10^{2} \mathrm{UFC} / \mathrm{g}$ & Ausência/25g & $1,4 \times 10^{4} \mathrm{UFC} / \mathrm{g}$ \\
\hline
\end{tabular}

Nota: Médias de 3 repetições.

Tabela 3. Coliformes totais, Coliformes fecais, Staphylococcus, Salmonella e Mesófilos em filés de tilápia submetidos à depuração e ao congelamento

\begin{tabular}{cccccc}
\hline $\begin{array}{c}\text { Depuração e } \\
\text { Congelamento } \\
\text { (Dias) }\end{array}$ & Coliformes Totais & $\begin{array}{c}\text { Coliformes } \\
\text { Fecais }\end{array}$ & $\begin{array}{c}\text { Staphylococcus } \\
\text { Salmonella }\end{array}$ & Mesófilos \\
\hline Controle & $0,7 \mathrm{NMP} / \mathrm{g}$ & $<0,3 \mathrm{NMP} / \mathrm{g}$ & $<10^{2} \mathrm{UFC} / \mathrm{g}$ & Ausência/25g & $2,1 \times 10^{3} \mathrm{UFC} / \mathrm{g}$ \\
3 & $1,1 \times 10 \mathrm{NMP} / \mathrm{g}$ & $0,7 \mathrm{NMP} / \mathrm{g}$ & $<10^{2} \mathrm{UFC} / \mathrm{g}$ & Ausência/25g & $2,0 \times 10^{3} \mathrm{UFC} / \mathrm{g}$ \\
7 & $5,4 \times 10 \mathrm{NMP} / \mathrm{g}$ & $0,7 \mathrm{NMP} / \mathrm{g}$ & $<10^{2} \mathrm{UFC} / \mathrm{g}$ & Ausência/25g & $4,2 \times 10^{3} \mathrm{UFC} / \mathrm{g}$ \\
\hline
\end{tabular}

Nota: Médias de 3 repetições.

A menção de contagem <0,3 para a metodologia de tubos múltiplos utilizada, significa que nenhum dos tubos inoculados se mostrou positivo, podendo ser encarada como ausência de coliformes fecais/g de peixe.

\subsubsection{Análises Físico-Químicas}

\subsubsection{Composição Centesimal}

A Tabela 4 apresenta as variações para os teores de umidade, proteína, lipídeos e cinza em filés de tilápia durante os dias de depuração. Os valores de umidade não foram afetados, significativamente, (Teste F) pelos dias de depuração. Os valores 
encontrados variam de 77,95 a 80,43g/100g estando de acordo com o citado por Ferreira (1987) que variaram de 76 a 81g/100g.

Segundo Beirão et al (2000) a umidade pode variar de 70 e 85g/100g em peixes, crustáceos e moluscos.

Para proteína, os dias de depuração não foram significativos (Teste F). Os valores médios variaram de 16,87 a 18,51 g/100g e estão de acordo com os apresentados por Soccol et al. (2002) para a mesma espécie, da ordem de 15 a 18 g/100g, Em estudo realizado por Biato et.al (2003) os autores encontraram valores médios de 22,88g/100g de proteína para a mesma espécie.

A fração cinza dos filés de tilápia não foi afetada, significativamente (Teste F), pelos dias de depuração. Os valores médios variaram de 0,93 a 1,11g/100g, estando de acordo com os valores relatados por Biato et.al (2003) e Soccol et al. (2002) que se estenderam de 0,84 a 1,46 g/100g. Segundo Beirão et al. (2000) o teor de cinza pode variar de 1 a 1,5g/100g em peixes, crustáceos e moluscos.

Os diferentes dias de depuração não apresentaram diferenças significativas entre si (Teste F) em relação ao teor de lipídeos, estes variaram de 1,53 a 1,84 g/100g, estando de acordo com os valores encontrados por Beirão et al. (2000) que foram de $1 \mathrm{a}$ 10g/100g. 
Tabela 4. Umidade, proteína, lipídeos e cinza (g/100g) em filés de tilápia submetidos à depuração por 3, 5 e 7 dias e no controle

\begin{tabular}{|c|c|c|}
\hline & uração (dias) & Composição Centesimal (g/100g) \\
\hline \multicolumn{3}{|l|}{ UMIDADE } \\
\hline & Controle & $80,43^{\mathrm{A}} \pm 1,00$ \\
\hline & 3 & $79,23^{\mathrm{A}} \pm 0,45$ \\
\hline & 5 & $77,95^{\mathrm{A}} \pm 1,12$ \\
\hline & 7 & $79,13^{\mathrm{A}} \pm 1,19$ \\
\hline \multicolumn{3}{|l|}{ PROTEÍNA } \\
\hline & Controle & $16,87^{\mathrm{A}} \pm 1,84$ \\
\hline & 3 & $17,11^{\mathrm{A}} \pm 2,53$ \\
\hline & 5 & $18,51^{\mathrm{A}} \pm 3,20$ \\
\hline & 7 & $17,72^{\mathrm{A}} \pm 2,86$ \\
\hline \multicolumn{3}{|l|}{ LIPÍDEOS } \\
\hline & Controle & $1,53^{\mathrm{A}} \pm 0,09$ \\
\hline & 3 & $1,74^{\mathrm{A}} \pm 0,57$ \\
\hline & 5 & $1,66^{\mathrm{A}} \pm 0,36$ \\
\hline & 7 & $1,84^{\mathrm{A}} \pm 0,29$ \\
\hline \multicolumn{3}{|l|}{ CINZA } \\
\hline & Controle & $0,93^{\mathrm{A}} \pm 0,07$ \\
\hline & 3 & $1,07^{\mathrm{A}} \pm 0,04$ \\
\hline & 5 & $1,11^{\mathrm{A}} \pm 0,10$ \\
\hline & 7 & $1,06^{\mathrm{A}} \pm 0,05$ \\
\hline
\end{tabular}

Médias seguidas pela mesma letra não diferem pelo teste de Tukey a 5\%; CV umidade= 1,31\%; CV proteína= 9,86\%; CV lipídeos= 16,92\%; CV cinza= 7,19\% 


\subsubsection{Nitrogênio não protéico - NNP}

A Tabela 5 apresenta os dados da variação do NNP em filés de tilápia durante os dias de depuração. Os valores de NNP não foram afetados, significativamente, (Teste F) pelos dias de depuração.

De acordo com Netto (1984), a tilápia do Nilo (Oreochromis niloticus) apresentou, no estado fresco, $494 \mathrm{mg}$ NNP/100g. Biato et al. (2003), encontraram o teor de 577,85 mg/100g, de NNP, para a mesma espécie in natura.

Tabela 5. Nitrogênio não protéico - NNP (mg/100g) em filés de tilápia submetidos à depuração por 3, 5 e 7 dias e no controle

\begin{tabular}{cc}
\hline Depuração (dias) & NNP $(\mathrm{mg} / 100 \mathrm{~g})$ \\
\hline Controle & $538,73^{\mathrm{A}} \pm 24,93$ \\
3 & $551,90^{\mathrm{A}} \pm 68,59$ \\
5 & $591,52^{\mathrm{A}} \pm 62,91$ \\
7 & $583,32^{\mathrm{A}} \pm 46,94$
\end{tabular}

Médias seguidas pela mesma letra não diferem pelo teste de Tukey a 5\%; CV= 8,89\%

\subsubsection{3 pH}

A Tabela 6 apresenta os valores obtidos para o $\mathrm{pH}$ em filés de tilápia. Os valores de $\mathrm{pH}$ não foram afetados, significativamente, $(\mathrm{p}>0,05)$ pelos dias de depuração.

O Regulamento da Inspeção Industrial e Sanitária de Produtos de Origem Animal - RIISPOA (BRASIL, 2004a) estabelece limites máximos de pH de 6,5 na parte interna do pescado fresco. Os valores encontrados no trabalho estão um pouco acima dos exigidos pela legislação. 
Tabela 6. pH em filés de tilápia submetidos à depuração por 3, 5 e 7 dias e no controle

\begin{tabular}{cc}
\hline Depuração (dias) & $\mathrm{pH}$ \\
\hline Controle & $6,57^{\mathrm{A}} \pm 0,12$ \\
3 & $6,56^{\mathrm{A}} \pm 0,09$ \\
5 & $6,55^{\mathrm{A}} \pm 0,13$ \\
7 & $6,53^{\mathrm{A}} \pm 0,14$ \\
\hline
\end{tabular}

Médias seguidas pela mesma letra não diferem pelo teste de Tukey a 5\%; CV= 2,00\%

Segundo Sikorski et al. (1994) a estabilidade do $\mathrm{pH}$ se deve ao efeito tamponante do músculo do pescado. Esse efeito é atribuído a presença de proteínas solúveis, peptídeos, aminoácidos, amônia, trimetilamina e substâncias solúveis, de baixo peso molecular que podem mascarar as mudanças de $\mathrm{pH}$, fazendo com que os valores de $\mathrm{pH}$ do músculo do pescado aumentem de forma lenta no início e, rapidamente, no processo da deterioração.

\subsubsection{Bases nitrogenadas voláteis totais - BNVT}

Os valores de BNVT não foram afetados, significativamente (Teste F), pelos dias de depuração (Tabela 7).

Segundo a legislação, o valor máximo permitido para BNVT é de 30mg/100g (BRASIL, 2004a; Kuaye, 1982; Sikorski et al., 1994). Os valores encontrados nesta pesquisa estão de acordo com os preconizados pela legislação.

Kuaye (1982) descreve que os teores de BNVT variam de acordo com a metodologia, a espécie de pescado e o estágio de alteração post mortem deste, sendo pouco sensíveis para pescado de água doce, onde não foram observadas alterações importantes, mesmo após vários dias de estocagem em gelo. 
Tabela 7. Bases nitrogenadas voláteis totais - BNVT (mg/100g) em filés de tilápia submetidos à depuração por 3, 5 e 7 dias e no controle

\begin{tabular}{cc}
\hline Depuração (dias) & BNVT (mg/100g) \\
\hline Controle & $9,87^{\mathrm{A}} \pm 1,88$ \\
3 & $8,40^{\mathrm{A}} \pm 0,70$ \\
5 & $8,64^{\mathrm{A}} \pm 0,45$ \\
7 & $8,01^{\mathrm{A}} \pm 0,58$ \\
\hline
\end{tabular}

Médias seguidas pela mesma letra não diferem pelo teste de Tukey a 5\%; CV=6,73\%

\subsubsection{Análise sensorial}

Para os atributos odor e sabor houve diferença significativa $(p>0,05)$ entre o tempo de depuração (Tabelas 8 e 9).

Tabela 8. Atributo odor dos filés de tilápia quanto a presença de off flavor (médias das notas atribuídas)

\begin{tabular}{cc}
\hline Depuração (dias) & Notas (médias) \\
\hline Controle & $4,98^{\mathrm{A}} \pm 1,33$ \\
3 & $3,15^{\mathrm{B}} \pm 0,25$ \\
5 & $2,64^{\mathrm{BC}} \pm 0,29$ \\
7 & $1,95^{\mathrm{C}} \pm 0,38$
\end{tabular}

Médias seguidas pela mesma letra não diferem pelo teste de Tukey a 5\%; CV= 10,24\%

Inicialmente, os peixes que correspondem ao controle apresentaram maior intensidade de odor e sabor (off flavor) quando comparados aos demais. O tratamento de 3 dias, para o atributo odor, foi igual, estatisticamente, ao tratamento de 5 dias e diferente do tratamento de 7 dias. O tratamento de 5 dias foi semelhante, estatisticamente, ao tratamento de 7 dias. Para o atributo sabor, os tratamentos de 3, 5 e 7 dias não diferiram, estatisticamente, entre si. 
Tabela 9. Atributo sabor dos filés de tilápia quanto a presença de off flavor (médias das notas atribuídas)

\begin{tabular}{cc}
\hline Depuração (dias) & Notas (médias) \\
\hline Controle & $6,18^{\mathrm{A}} \pm 1,10$ \\
3 & $2,44^{\mathrm{B}} \pm 0,64$ \\
5 & $1,92^{\mathrm{B}} \pm 0,24$ \\
7 & $1,80^{\mathrm{B}} \pm 0,16$ \\
\hline
\end{tabular}

Médias seguidas pela mesma letra não diferem pelo teste de Tukey a 5\%; CV= 11,76\%

Lovshin \& Cyrino (1998) relatam que a tilápia (Oreochromis, sp) adquire off flavor existente nas algas azuis-verde e outros microrganismos, portanto, para assegurar a qualidade, a tilápia deve ser mantida em água limpa por três a cinco dias como medida para depurar o off flavor seja depurado.

Segundo Kubitza (2000) o tempo necessário para a depuração de peixes portadores de off flavor depende de diversos fatores, entre eles a temperatura da água nos tanques de depuração, o teor de lipídeos dos peixes e a intensidade inicial do off flavor.

\subsection{Conclusões}

A perda de peso dos peixes foi mais intensa nos três primeiros dias de depuração; depois desse período, houve estabilização não ocorrendo perda significativa.

Através das análises microbiológicas comprovou-se que os peixes estavam dentro dos limites estabelecidos pela legislação, em relação aos microorganismos de interesse.

O processo de depuração dá bons resultados quanto a eliminação de off flavor da tilápia, desde que o tempo de depuração seja de 5 dias em tanque com água corrente e limpa, isenta de geosmina e algas. 


\section{UTILIZAÇÃO DA DEFUMAÇÃO COMO MEIO DE MASCARAR O OFF FLAVOR EM TILÁPIA DO NILO (Oerochrmis niloticus).}

\section{Resumo}

Este estudo teve por objetivo a utilização da defumação como meio de mascarar o off flavor presente no filé de tilápia do Nilo. Os peixes que não sofreram depuração (controle), foram submetidos à defumação. Os filés de peixe in natura e os defumados foram comparados entre si, quanto a composição centesimal e verificou-se que estes foram afetados significativamente (Teste F). Para o nitrogênio não protéico NNP, as bases nitrogenadas voláteis totais - BNVT e o pH não houve alteração significativa $(p>0,05)$ quanto aos tratamentos. Através das análises sensoriais verificouse que os peixes in natura apresentaram maior intensidade de off flavor quando comparados aos defumados. Para os atributos odor e sabor houve diferença significativa $(\mathrm{p}>0,05)$ entre os tratamentos. Quando se comparou o pescado defumado com o pescado in natura, o primeiro recebeu uma maior aceitação pelos degustadores. O processo de defumação é uma forma de mascarar a presença do off flavor; é um processo simples, pouco oneroso e que pode ser adotado prontamente pelos produtores como forma de agregar valor ao pescado.

\section{Summary}

The objective of this study was to use smoking as a way of disguising the off flavor in Nile tilapia fillets. The fish which did not go through depuration (control) were submitted to smoking. The fresh fish and the smoked fillets were compared as to the centesimal composition and verified to have been significantly affected ( $F$ test). No significant differences $(\mathrm{p}>0.05)$ were detected as to non-protein nitrogen $-\mathrm{NPN}$, total 
volatile nitrogenous bases -TVB-N, and $\mathrm{pH}$ among the different treatments. Through sensory analyses, we verified that the fresh fish presented a more intense off-flavor, when compared to the smoked ones. As to odor and flavor, there was a significant difference ( $p>0.05$ ) among the treatments. When compared to the fresh fish, the smoked samples was better accepted by the panelists. The smoking process is a way of disguising off-flavor. It is also a simple, inexpensive process, which can be readily adopted by producers as a way of adding value do the fish.

\subsection{Introdução}

Quando realizada de maneira convencional a defumação tem como finalidade estender a vida útil do produto, devido aos efeitos combinados da salga, cocção, secagem e deposição de substâncias químicas bactericidas, presentes na fumaça. No século $\mathrm{XV}$, com o desenvolvimento da pesca do arenque, tal processo, alcançou características verdadeiramente industriais, e desde então evoluíram as técnicas e equipamentos, chegando a atingir os atuais padrões de qualidade (Machado, 1984).

Além da obtenção de um produto processado, a técnica de defumação convencional de peixes é, hoje em dia, empregada com finalidades preservativas (Homer, 1992), bem como para obter um produto característico por suas qualidades sensoriais, de excelente palatabilidade (Morais, 1994).

A ocorrência do sabor "terra/mofo" (off flavor) em peixes de água doce cultivados causa prejuízos econômicos consideráveis para os aqüicultores. Uma das técnicas utilizadas para mascarar esse sabor é a defumação. A defumação a quente tem sido utilizada com grande sucesso para mascarar o off flavor. Há evidências de que esse tipo de processamento é mais efetivo em neutralizar o sabor de "barro" do que o odor (Iredale \& Rigby, 1972). 


\subsection{Material e métodos}

\subsubsection{Processamento do pescado defumado}

Parte dos filés de peixes não depurados (controle) foi submetida a defumação. Os peixes foram processados, conforme descrito no item 4.2.2. do capítulo 4, tratados por salmouragem a 25\% (peso/volume) por 10 min e lavados em água corrente. A seguir, foram colocados em secador de armário a $55^{\circ} \mathrm{C}$ por 30 min e em seguida no defumador de alvenaria por cerca de $5 \mathrm{~h}$, com temperatura média da câmara de $75^{\circ} \mathrm{C}$ (Oetterer, 2002). Os peixes defumados foram submetidos às análises descritas abaixo.

\subsubsection{Análises microbiológicas}

As análises microbiológicas para o pescado defumado foram realizadas nos peixes (controle) capturados nos três blocos e conduzidas em triplicata para cada bloco. As metodologias utilizadas para as análises convencionais seguiram as recomendações de Vanderzant \& Splittstoesser (1992) e Silva et al. (1997). O preparo das amostras foi feito pela técnica da enxaguadura, onde $100 \mathrm{~g}$ de filés de tilápia, com espessura de, aproximadamente, 0,5 cm foram misturados com $100 \mathrm{~mL}$ de água peptonada tamponada (1:1) e submetidos a agitação manual vigorosa por 50 vezes. Para efeito de diluição, $1 \mathrm{~mL}$ pipetado desta enxaguadura correspondia a $1 \mathrm{~g}$ de peixe. As diluições $10^{-}$ ${ }^{1}$ a $10^{-4}$ foram preparadas diluindo-se $10 \mathrm{~mL}$ da amostra em $90 \mathrm{~mL}$ de água peptonada, $0,1 \%$ e esterilizada. Os microrganismos analisados foram:

\subsubsection{Coliformes totais e coliformes fecais}

Utilizou-se a técnica de tubos múltiplos, série de 5 tubos, para a estimativa do Número Mais Provável (NMP). Para a prova presuntiva, inoculou-se $10 \mathrm{~mL}$ da diluição $10^{-2}$ nos 5 tubos contendo Caldo Lauril Sulfato de Sódio em concentração dupla. Inoculou-se volumes de $1 \mathrm{~mL}$ da diluição $10^{-2}$ em uma série de 5 tubos contendo Caldo Lauril Sulfato de Sódio em concentração simples, e volumes de $1 \mathrm{~mL}$ da diluição $10^{-3}$, em outra série de 5 tubos contendo o mesmo meio. Incubaram-se os tubos a $36^{\circ} \mathrm{C} \pm$ $1^{\circ} \mathrm{C}$, por 48 horas. A positividade foi indicada pelo crescimento e presença de gás nos 
tubos de Duhram. Para a confirmação de coliformes totais, repicou-se os tubos positivos do Caldo Lauril Sulfato de Sódio para tubos de Caldo Verde Brilhante Bile 2\% lactose, que foram incubados a $36^{\circ} \mathrm{C} \pm 1^{\circ} \mathrm{C}$, por $48 \mathrm{~h}$. Para a prova confirmatória de coliformes fecais, repicou-se os tubos positivos do Caldo Lauril Sulfato de Sódio para tubos de caldo EC, incubando-os a $45^{\circ} \mathrm{C} \pm 0,2^{\circ} \mathrm{C}$, por $48 \mathrm{~h}$, em banho-maria, com agitação. A presença de gás indica positividade do tubo para a presença de coliformes totais (CVBLB 2\%) e de coliformes fecais (EC). Através da combinação do número de tubos positivos, em cada série de diluição, nos testes para coliformes totais e fecais, e consultando-se a Tabela de Número Mais Provável, obteve-se NMP de coliformes totais/g de amostra e coliformes fecais/g (APHA, 1998; Hitchins et al., 2004).

\subsubsection{Salmonella spp}

Para a deteç̧ão presuntiva de Salmonella, utilizou-se o kit 1-2 Salmonella (Aprovado pela AOAC em 2000). Foi realizado um pré-enriquecimento de cada amostra analisada, inoculando-se 25 g de pescado em um erlenmeyer contendo $225 \mathrm{~mL}$ de caldo lactosado. Os frascos foram incubados a temperatura de $37^{\circ} \mathrm{C}$, por 24 h. Após o período de incubação, transferiu-se $0,1 \mathrm{~mL}$ da amostra pré-enriquecida para o kit, incubando-o a $35^{\circ} \mathrm{C}$, por $14-30 \mathrm{~h}$.

\subsubsection{Staphylococcus coagulase positiva}

Para a análise de $S$. Coagulase positiva foram utilizadas placas com meio Agar Baird-Parker (BPA), através do espalhamento do inóculo na superfície, com a alça de Drigalsky. Da diluição $10^{-1}$ espalhou-se $0,1 \mathrm{~mL}$ em duas placas com o meio; o mesmo procedimento foi adotado para a diluição $10^{-2}$ e para a diluição $10^{-3}$. Após a absorção do inóculo, as placas foram invertidas e incubadas a $35-37^{\circ} \mathrm{C}$ por $24-48 \mathrm{~h}$. Após este período, procedeu-se a contagem das colônias típicas (pretas, pequenas, lisas e com halo). Para a confirmação das colônias típicas foram realizados coloração de Gram e provas de catalase e coagulase. 


\subsubsection{Análises físico-químicas}

As análises físico-químicas estão descritas a seguir

5.2.3.1 Umidade: determinada por gravimetria, de acordo com a Association of Official Analytical Chemists - AOAC (1995).

5.2.3.2 Proteína bruta: mediante a determinação do nitrogênio total, pelo método Kjeldahl, de acordo com AOAC (1995).

5.2.3.3 Lipídeos: determinados através do método de Soxhlet, utilizando hexano como solvente, conforme descrito pela AOAC (1995).

5.2.3.4 Cinza: por incineração da matéria orgânica, de acordo com AOAC (1995).

\subsubsection{Nitrogênio não protéico (NNP)}

Determinado por precipitação das proteínas musculares com ácido tricloroacético (TCA), seguida de avaliação do nitrogênio não protéico presente no extrato TCA, através do método Micro Kjeldhal, de acordo com AOAC (1995).

\subsubsection{Bases nitrogenadas voláteis totais (BNVT)}

Determinadas por meio de precipitação protéica com ácido tricloroacético (TCA), e destilação de alíquotas de $20 \mathrm{~mL}$ do filtrado; recebimento do destilado em ácido bórico, a 1\%, com indicador misto e titulação com ácido clorídrico, 0,02 N, conforme descrito por Morga (1975).

\subsubsection{Determinação de $\mathrm{pH}$}

Determinado em potenciômetro digital Digimed, utilizando o músculo homogeneizado em água destilada, na proporção 1:1. 


\subsubsection{Análise sensorial}

\subsubsection{Seleção preliminar dos provadores}

Inicialmente foi realizada uma pré-seleção com 20 pessoas que costumam consumir peixes. Utilizou-se o teste de comparação pareada onde cada provador recebeu 2 amostras de peixe, uma com muito off flavor (peixes que não sofreram depuração) e a outra constituída de filés de tilápia defumada. Os provadores foram solicitados a provarem as amostras da esquerda para a direita (aleatoriamente) e identificarem qual amostra possui maior intensidade de off flavor. Foram realizadas 5 sessões consecutivas por 5 dias. O critério usado para a seleção de provadores considerou o mínimo de $60 \%$ de acertos no total de testes realizados.

\subsubsection{Levantamento de atributos}

Foram realizadas 2 sessões e em cada sessão foram apresentadas duas amostras de peixe, uma muito off flavor e a outra filés de tilápia defumada, solicitandose que o provador anotasse as similaridades e as diferenças entre os peixes.

\subsubsection{Elaboração das fichas individuais}

Após as sessões de levantamento de termos e discussão individual com os provadores foram montadas as listas de atributos de cada provador. Com as listas de atributos de cada provador foram então elaboradas as fichas com escalas de intensidade. Foram empregadas mais 2 sessões para testar as fichas, já simulando o teste definitivo.

\subsubsection{Procedimento para análise sensorial}

Foi utilizada uma equipe de 10 provadores treinados previamente, onde foram definidas escalas para avaliação do aroma e sabor dos peixes. Para a medida da intensidade dos atributos (odor e sabor), foi utilizada uma escala estruturada variando de muito off flavor (nota 9) a nenhum off flavor (nota 1). As amostras foram apresentadas aos provadores em pratos de cerâmica, codificados com números de 3 dígitos e selecionados aleatoriamente. Foram servidos aos provadores, filés de peixes in 
natura não depurados (controle) e filés de peixes que foram submetidos a defumação. Para a análise de sabor, o pescado in natura não depurado foi cortado em pedaços de $4 \mathrm{~cm}^{2}$, embrulhado em folha de papel encerado, submetido à cocção em microondas, por 40 seg, e servido aos provadores. Para as análises de odor, o pescado foi servido cru; o pescado defumado foi servido em temperatura ambiente para as análises de odor e sabor.

\subsubsection{Análise estatística}

O delineamento experimental adotado foi o de blocos casualizados, com 2 tratamentos e 3 blocos, sendo cada época de coleta considerada como um bloco. Os dados obtidos foram submetidos ao teste $\mathrm{F}$ da análise de variância (PROC GLM) através do programa SAS (1999) e, posteriormente, as médias foram comparadas, pelo teste de Tukey, a 5\% de probabilidade.

Os dados relativos às análises microbiológicas não foram comparados, estatisticamente, por terem sido utilizados neste estudo somente para garantir um produto adequado ao consumo pelos provadores.

\subsection{Resultados e discussão}

\subsubsection{Análises microbiológicas}

A Resolução RDC n 12, de 2 de janeiro de 2001 da Agência Nacional de Vigilância Sanitária (BRASIL, 2004c), apresenta padrão para coliformes totais/g e fecais/g de, no máximo, $10^{2} \mathrm{NMP} / g$, para pescado defumado. Neste trabalho todos os valores encontrados para coliformes, no pescado defumado, estão abaixo dos limites estabelecidos pela legislação (Tabela 1).

A legislação também apresenta padrão para Staphylococcus de, no máximo, 5 x $10^{2}$ UFC/g e para Salmonella a ausência em 25g, para o pescado defumado. Através da Tabela 13 pode-se observar que todos os valores encontrados para Staphylococcus e Salmonella estão de acordo com a legislação. 
Tabela 1. Coliformes totais, Coliformes fecais, Staphylococcus e Salmonella em filés de tilápia submetidos a defumação

\begin{tabular}{ccccc}
\hline Lotes & Coliformes totais & Coliformes fecais & Staphylococcus & Salmonella \\
\hline 1 & $<0,3 \mathrm{NMP} / \mathrm{g}$ & $<0,3 \mathrm{NMP} / \mathrm{g}$ & $<10^{2} \mathrm{UFC} / \mathrm{g}$ & Ausência/25g \\
2 & $<0,3 \mathrm{NMP} / \mathrm{g}$ & $<0,3 \mathrm{NMP} / \mathrm{g}$ & $<10^{2} \mathrm{UFC} / \mathrm{g}$ & Ausência/25g \\
3 & $<0,3 \mathrm{NMP} / \mathrm{g}$ & $<0,3 \mathrm{NMP} / \mathrm{g}$ & $<10^{2} \mathrm{UFC} / \mathrm{g}$ & Ausência/25g
\end{tabular}

Nota: Médias de 3 repetições.

\subsubsection{Análises Físico-Químicas}

\subsubsection{Composição Centesimal}

A Tabela 2 apresenta a variação dos teores de umidade, proteína, lipídeos e cinza em filés de tilápia in natura e defumados. Os valores de todos os componentes foram afetados, significativamente, (Teste F) pelos tratamentos.

Os maiores valores de proteína e lipídeos observados nos filés defumados, em relação aos in natura, são decorrentes da desidratação ocorrida (Tabela 2), fato também reportado por Hassan (1998) e Gonçalves \& Prentice-Hernandez (1998). Os autores afirmam que, na defumação ocorre uma perda progressiva de umidade e um ligeiro aumento nos teores de lipídeos, acompanhado pelo aumento nos níveis de cinza e proteína.

De acordo com Cardinal et.al (2001), a umidade do músculo do produto defumado final não deve ser superior a 65\%, devido à possibilidade de degradação das características sensoriais e nutritivas. 
Tabela 2. Umidade, proteína, lipídeos e cinza (g/100g) de filés de tilápia in natura e defumados

\begin{tabular}{lcc}
\hline & Tratamentos & Composição Centesimal (g/100g) \\
\hline UMIDADE & In natura & $80,43^{\mathrm{A}} \pm 1,00$ \\
& Defumado & $64,04^{\mathrm{B}} \pm 3,95$ \\
PROTEÍNA & & \\
& In natura & $16,87^{\mathrm{A}} \pm 1,84$ \\
LIPÍDEOS & Defumado & $31,03^{\mathrm{B}} \pm 4,08$ \\
& & \\
CINZA & In natura & $1,53^{\mathrm{A}} \pm 0,09$ \\
& Defumado & $3,18^{\mathrm{B}} \pm 0,89$ \\
& In natura & $0,93^{\mathrm{A}} \pm 0,07$ \\
& Defumado & $3,73^{\mathrm{B}} \pm 0,53$ \\
\hline
\end{tabular}

Médias seguidas pela mesma letra não diferem pelo teste de Tukey a 5\%; CV umidade= 4,61; CV proteína= 12,35; CV lipídeos = 24,04; CV cinza= 18,26

\subsubsection{NNP}

A Tabela 3 apresenta os dados da variação do NNP em filés de tilápia nos tratamentos. Os valores de NNP não foram afetados, significativamente, (Teste F) pelos tratamentos.

Segundo Soccol et al. (2002) o teor de NNP de tilápia do Nilo in natura foi de 534,72 mg/100g. De acordo com Biato et al. (2003), a concentração de tilápia do Nilo defumada foi de $467,15 \mathrm{mg} / 100 \mathrm{~g}$. 
Tabela 3. Nitrogênio não protéico - NNP (mg/100g) em filés de tilápia in natura e defumados

\begin{aligned} \hline Tratamento & NNP $(\mathrm{mg} / 100 \mathrm{~g}) \\$\hline In natura & $538,73^{\mathrm{A}} \pm 24,93 \\$ Defumado & $530,29^{\mathrm{A}} \pm 39,10\end{aligned}$

Médias seguidas pela mesma letra não diferem pelo teste de Tukey a 5\%; CV= 8,30

\subsubsection{3 pH}

A Tabela 4 apresenta os valores obtidos para o pH em filés de tilápia. Os valores de $\mathrm{pH}$ não foram afetados, significativamente $(\mathrm{p}>0,05)$ pelos tratamentos.

De acordo com Southcott \& Razell (1973), o processo de defumação deve diminuir o $\mathrm{pH}$ do peixe fresco para 6,5 ou menos. $\mathrm{O}$ pH dos filés de tilápia defumados deste trabalho encontram-se de acordo com o recomendado pelos autores.

Tabela 4. pH em filés de tilápia in natura e defumados

\begin{tabular}{cc}
\hline Tratamento & $\mathrm{pH}$ \\
\hline In natura & $6,57^{\mathrm{A}} \pm 0,12$ \\
Defumado & $6,30^{\mathrm{A}} \pm 0,05$ \\
\hline
\end{tabular}

Médias seguidas pela mesma letra não diferem pelo teste de Tukey a 5\%; CV=1,81

\subsubsection{BNVT}

Pode-se observar, através da Tabela 5, que para os peixes in natura e os defumados os valores de BNVT ficaram abaixo do valor limite estabelecido pela legislação brasileira (30 mg/100g). Os valores de BNVT não foram afetados, significativamente, (Teste F) pelos tratamentos.

Para Soccol et al. (2002), o teor de BNVT da tilápia do Nilo in natura foi de $14 \mathrm{mg} / 100 \mathrm{~g}$. Biato et al (2003), encontraram valores de BNVT de 9,07mg/100g para tilápia do Nilo defumada. 
Tabela 5. Bases nitrogenadas voláteis totais - BNVT (mg/100g) em filés de tilápia in natura e defumados

\begin{tabular}{cc}
\hline Tratamento & BNVT $(\mathrm{mg} / 100 \mathrm{~g})$ \\
\hline In natura & $9,87^{\mathrm{A}} \pm 1,88$ \\
Defumado & $11,75^{\mathrm{A}} \pm 0,58$ \\
\hline
\end{tabular}

Médias seguidas pela mesma letra não diferem pelo teste de Tukey a 5\%; CV= 14,76

\subsubsection{Análise sensorial}

Para os atributos odor e sabor houve diferença significativa $(\mathrm{p}>0,05)$ entre os tratamentos (Tabelas 6 e 7). Os peixes in natura apresentaram maior intensidade de odor e sabor (off flavor) quando comparados aos defumados.

Tabela 6. Atributo odor dos filés de tilápia quanto à presença de off flavor

\begin{tabular}{cc}
\hline Tratamento & Notas (médias) \\
\hline In natura & $5,76^{\mathrm{A}} \pm 0,61$ \\
Defumado & $1,16^{\mathrm{B}} \pm 0,05$ \\
\hline
\end{tabular}

Médias seguidas pela mesma letra não diferem pelo teste de Tukey a 5\%; CV=13,37

Tabela 7. Atributo sabor dos filés de tilápia quanto à presença de off flavor

\begin{tabular}{cc}
\hline Tratamento & Notas (médias) \\
\hline In natura & $6,40^{\mathrm{A}} \pm 1,08$ \\
Defumado & $1,30^{\mathrm{B}} \pm 0,26$ \\
\hline
\end{tabular}

Médias seguidas pela mesma letra não diferem pelo teste de Tukey a 5\%; CV=17,52

Iredale \& Rigby (1972) estudaram a defumação como forma de atenuar o off flavor em trutas. Utilizando uma equipe de provadores concluíram que este processo consegue diminuir o odor e sabor semelhante ao “barro”. Andrade \& Lima (1983) testaram o efeito da defumação a quente e a frio em mandis (Pimelodus clarias). A carne desta espécie, normalmente, não é bem aceita por possuir off flavor, no entanto, a defumação a quente aplicada aos mandis serviu para mascarar este problema, resultando 
em um produto aceito pelos degustadores.

\subsection{Conclusões}

O pescado defumado estava de acordo com a legislação quanto a presença de microrganismos.

A defumação permite a atenuação do off flavor em tilápias cultivadas, como percebemos através das análises sensorias, onde os provadores preferiram o pescado defumado ao in natura quanto ao sabor e odor. 


\section{CONCLUSÕES GERAIS}

A qualidade da água está diretamente ligada a qualidade do pescado. Neste trabalho a água do tanque de cultivo apresentou problemas de eutrofização e presença de geosmina, condições que resultam em problemas de off flavor no pescado.

Através da análise qualitativa e quantitativa de algas e cianobactérias verificou-se que a água do tanque de cultivo apresenta concentrações altas de cianobactérias que causam odor e sabor de "barro" na água e consecutivamente no pescado.

A perda de peso dos peixes foi mais intensa nos três primeiros dias de depuração; depois desse período, houve estabilização não ocorrendo perda significativa. O processo de depuração dá bons resultados quanto a eliminação de off flavor da tilápia, desde que o tempo de depuração seja de 5 dias em tanque com água corrente e limpa, isenta de geosmina e algas.

A defumação permite a atenuação do off flavor em tilápias cultivadas, como percebemos através das análises sensorias, onde os provadores preferiram o pescado defumado ao in natura quanto ao sabor e odor. 


\section{REFERÊNCIAS BIBLIOGRÁFICAS}

AGUDO, E.G. (Coord.) Guia de coleta e preservação de amostras de água.São Paulo: CETESB, 1988. 76p.

AMERICAN WATER WORKS ASSOCIATION RESEARCH FOUDATION. Identification and tratment of taste and odors in drinking water. Denver: AWWA, 1987. 292p.

AMERICAN PUBLIC HEALTH ASSOCIATION. Standard methods for the examination of water and watestewater. 18ed. Washington: APHA, 1992. 1219p.

AMERICAN PUBLIC HEALTH ASSOCIATION. Standard methods for the examination of water and watestewater. 19ed. Washington: APHA, 1995. 875p.

AMERICAN WATER WORKS ASSOCIATION RESEARCH FOUDATION. Advances in taste and odor treatment and control. Denver: AWWA, 1995. 385p

AMERICAN PUBLIC HEALTH ASSOCIATION. Standard methods for the examination of water and watestewater. 20ed. Washington: APHA, 1998. 937p.

AMERIO, M.; RUGGI, C.; BUDINI, C. Meat quality of reared fish nutricional aspects. Italian Journal Food Science, v.8, n.3, p.221-229, 1996. 
ANDRADE, M.O.; LIMA, U.A. Aproveitamento tecnológico do mandi-defumação fria. Revista Brasileira de Tecnologia, v.1, n.1, p.201-206, 1975.

ANDRADE, M.O.; LIMA, U.A. Agroindústria de alimentos-produção de pescado defumado. O Solo, v.1, n.1, p.16-29. 1983.

ANON. Manuel des analyses chimiques en milieu. Best: Marin. Centre National pour l'Exploitation des Oceans - BNDO, 1983. 578p.

ARMSTRONG, M.S.; BOYD, C.E.; LOVELL, R.S. Environmental factors affecting flavor of channel catfish from production ponds. The Progressive Fish-Culturist, v.1, n.1, p.113-119, 1986.

ASSOCIATION OF OFFICIAL ANALYTICAL CHEMISTIS. Official methods of analysis. 16. ed. Arlington: AOAC,1995. v.2., p 1-30.

ASSOCIATION OF OFFICIAL ANALYTICAL CHEMISTIS. Official methods of analysis. 13. ed. Arlington, AOAC, 2000. 989p.

ATLAS, R.M., BARTHA, R. Microbial ecology. 2ed. Menlo Park: The Benjamin/Cummings, 1987. 533p.

AYROSA, L.M.S. Manejo e tratamento pós-colheita de peixes de água doce destinados à salga e defumação. In: SEMINÁRIO SOBRE TECNOLOGIA DE SALGA E DEFUMAÇÃO DE PESCADO. Guarujá, 1995. Anais. Campinas: ITAL, 1995. p.25-50.

BARD, J. Piscicultura intensiva de tilápias. Informe Agropecuário, v.6, n.67, p.24-29, 1980. 
BEIRÃO, L.H.; TEIXEIRA, E.; MEINERT, E.M. et al. Processamento e industrialização de moluscos. In: SEMINÁRIO E WORKHOP “TECNOLOGIA PARA APROVEITAMENTO INTEGRAL DE PESCADO”. Campinas, 2000. Resumos. Campinas: ITAL, 2000. p.38-84.

BENANOU, D.; ACOBAS, F.; ROUBIN, M. R.; DAVID, F.; SANDRA, P. Analysis of off-flavors in the aquatic environment by stir bar sorptive extraction-thermal desorption-capillary GC/MS/olfactometry. Analysis Bioanalysis Chemistry, v.1, n.1, p.69-77, 2003.

BEVERIDGE, M.C.M. Cage and pen fish farming: carrying capacity models and environmental impact. Fishey Technical Paper. Rome: FAO 1984. 131p

BEVERIDGE, M.C.M. Cage aquaculture.London: Fishing News Books, 1987. 351p.

BEYRUTH, Z. Comunidade Fitoplanctônica da Represa de Guarapiranga: 1991-1992. Aspectos Ecológicos, Sanitários e Subsídios para Reabilitaçãoda Qualidade Ambiental. São Paulo, 1996; 191p. Tese (Doutorado) - Faculdade de Saúde Pública, Universidade de São Paulo.

BIATO, D.; RIBEIRO, G. OETTERER, M.; SPOTO, M. Qualidade do pescado in natura proveniente de cultivo, com enfoque na deteç̧ão de off flavour. In: ENCONTRO CIENTÍFICO DOS PÓS-GRADUANDOS NO CENA/USP.9., Piracicaba, 2003. Anais. Piracicaba: CENA/USP, 2003. p.125-127.

BOYD, C.E. Effluents from catfish ponds during fish harvest. Journal of Environmental Quality, v.7, p.59-62, 1978.

BOYD, C.E. Water quality management for pond fish culture. New York: Elsevier. 1990. p.197-253. 
BOYD, C.E. Manejo do solo e da qualidade da água em viveiros para aquicultura. Campinas: Mogiana Alimentos. 1997. 55p.

BOYD, C.E. Pond water aeration systems. Aquacultural Engineering. v.18, p.9-40, 1998.

BRANCO, S.M. Hidrologia aplicada à engenharia sanitária. 3 ed. São Paulo: CETESB/ ASCETESB, 1986. 395p.

BRASIL. Ministério da Agricultura, Pecuária e Abastecimento. Regulamento da inspeção industrial e sanitária de produtos de origem animal (RIISPOA). Pescados e derivados, C.7, seção 1. Brasília, 2001. www.agricultura.gov.br/sda . (22 mar 2004a)

BRASIL. Ministério do Meio Ambiente. Conselho Nacional do Meio Ambiente (CONAMA). Resolução CONAMA $\mathbf{n}^{\circ} 20,18$ de junho de 1986. www.mma.gov.br. (12 abr 2004b)

BRASIL. Ministério da Saúde. Agência Nacional de Vigilância Sanitária (ANVISA). Resolução - RDC $\mathbf{n}^{0}$ 12, de 02 janeiro de 2001: regulamento técnico sobre padrões microbiológicos para alimentos. www.anvisa.gov.br. (2 jun 2004c)

BROWN, S.W.; BOYD, C.E. Off-flavor in channel catfish from commercial ponds. Transactions of the American Fishies Society, v.1, n.1, p.379-383, 1982.

CARDINAL, M.; KNOCKAERT, C.; TORRISSEN, O.; SIGURGISLADOTTIR, S.; MORKORE, T.; THOMASSEN, M.; VALLET, J.L. Relation of smoking parameters to the yield, colour and sensory quality of smoked Atlantic salmon (Salmo solar). Food Research International, v.34, p.537-550, 2001. 
CASTAGNOLLI, N. Criação de peixes de água doce. Jaboticabal: FUNEP, 1992. 189p.

COMPANHIA DE TECNOLOGIA DE SANEAMENTO AMBIENTAL. Relatório da qualidade das águas interiores do estado de São Paulo 2000. São Paulo: CETESB, 2000. (Relatórios CETESB)

CLUCAS, I.J.; WARD, A.R. Post-harvest fisheries development. A guide to handling, preservation, processing and quality. London: National Resouries Institute, 1996. 177p.

COLE, B.A.; BOYD, C.E. Feeding rate, water quality, and channel catfish production in ponds. Progressive Fish-Culturist, v.81, p.25-29, 1986.

CONNELL, J.J. Control of fish quality. Surrey: Fishing News, 1975. 179 p.

DASSO, I. Qué ponemos en jurgo al degustar un alimento? La Alimentación Latinoamericana, v.33, n.229, p.34-36, 1999.

FERREIRA, S.O. Aplicação de tecnologia a espécies de pescado de água doce visando atender a agroindústria rural. Piracicaba, 1987. 122p. Dissertação (Mestrado) Escola Superior de Agricultura “Luiz de Queiroz”, Universidade de São Paulo.

FERREIRA FILHO, S.S. Otimização da aplicação do carvão ativado em pó no tratamento de agua visando a redução de compostos orgánicos causadores de odor e sabor em águas de abastecimento. Revista Engenharia Sanitaria e Ambiental, v.1, n.4, 1996. 263p. 
FERREIRA FILHO, S.S. Remoção de compostos orgânicos causadores de gusto e odor em agues de abastecimento: modelação matemática e otimização do processo de absorção em carvão ativado em pó para o sistema produtor de Guarapiranga. São Paulo, 2001. 333p. Tese (Livre Docência) - Escola Politécnica, Universidade de São Paulo.

FITZSIMMONS, K. Tilapia: the most important aquaculture species of the $21^{\text {st }}$ century. In: INTERNACIONAL SYMPOSIUM ON TILAPIA AQUACULTURE, 1., Rio de Janeiro, 2000. Resumos.Rio de Janeiro: s.ed, 2000. p3-8.

FREITAS, J.V.F.; GURGEL, J.J.S. Estudos experimentais sobre a conservação da tilápia do Nilo, Oreochromis niloticus (L., 1766), armazenada no gelo. Boletim Técnico do Departamento Nacional de Obras Contra a Seca, v.42, n.2, p.153178, 1984.

GENTIL, R.C. Variação sazonal do fitoplâncton de um lago subtropical eutrófico e aspectos sanitários, São Paulo, SP. São Paulo, 2000. 186p. Dissertação (Mestrado) Faculdade de Saúde Pública, Universidade de São Paulo.

GOLTERMAN, H.L.; CLYMO, R.S.; OHNESTAND, M.A.M. Methods for physical and chemical analysis of fresh water. New York: Bleckwell Sci.Publ. 1978. 213p. (IBP Handbook, n.8).

GONÇALVES, A.A.; PRENTICE-HERNANDEZ, C. Defumação líquida de anchova (Pomatomus saltatrix): Efeito do processamento nas propriedades químicas e microbiológicas. Ciência e Tecnologia de Alimentos, v.18, n.4, p.438-443, 1998.

GRIMM, C.C.; LLOYD, S.W.; ZIMBA, P.V. Instrumental versus sensory detection of off-flavors in farm-raised channel catfish. Aquaculture, v.236, n.1-4, p.309-319, 2004. 
HASSAN, I.M.; Processing of smoked common carp fish and its relations to some chemical, physical and organoleptic properties. Food Chemistry, v.27, p.95-106, 1988.

HITCHINS, A.D.; FENG, P.; WATKINS, W.D.; RIPPEY, S.R.; CHANDLER, L.A. Escherichia coli and the coliform bacteria. www.cfsan.fda.gov. (15 maio 2004).

HOMER, W.F.A. Preservation of fish by curing (drying, salting and smoking). In: Hall, G.M. Fish processing technology. New York: VCH Publishrers, 1992, p.3171.

HUSS, H.H.; DALSGAARDE, D.; HANSEN, L. et al. The influence of higiene in cacth handling on the storege life of iced cod and plaice. Journal of Food Tecnology, v.4, n.9, p.213-221, 1974.

IREDALE, D.G. Problems in the utilization of freshwater fish. Fishery Products, v.2, n.9, p.267-269, 1974.

IREDALE, D.G.; RIGBY, D. Effect of smoke processing on muddy odor and taste in rainbow trout (Salmo gairdneri) Journal Fisheries Research Board of Canada, v.29, n.9, p. 1365-1366, 1972.

IREDALE, D.G. ; YORK, R.K. Purging a muddy earthy flavor taint from rainbow trout (Salmo gairdneri) by transferring to artificial and natural holding environments. Journal of the Fisheries Research Board of Canada, v.33, n.1, p.160-166, 1976

JOHNSEN, P.B. Aquaculture product quality issues: market position opprtunities under mandotory seafood inspection regulations. Journal of Animal Science, n.69. p.4209-4215. 1991. 
JOHNSEN, P.B.; LLOYD, S.W.; VINYARD, B.T.; DIOGINI, C.P. Effects of temperature on the uptake and depuration of the off flavor metabolite 2methylisoborneol by Channel Catfish (Ictalurus punctatus). Canadian Journal of Fishery and Aquatic Science, v.27, n.1, p.15-20, 1996

JORNAL CONSUMIDORSA

$\mathrm{ON}$ LINE. www.server.digipronto.com.br/idec.org.br/consumidorsa/0114. (18 abr. 2004)

JORY, D.E.; ALCESTE, C.; CABRERA, T.R. Mercado y comercialización de tilapia en los Estados Unidos de Norteamérica. Panorama Acuícola, v.5, n.5, p.50-53, 2000.

KUAYE, A.Y. Comparação dos métodos para determinação das bases nitrogenadas voláteis em pescado: parâmetros críticos e modificações. Campinas, 1982. 95p. Dissertação (Mestrado) - Faculdade de Engenharia de Alimentos e Agrícola, Universidade Estadual de Campinas.

KUBITZA, F. “Off-flavor”, nutrição, manejo alimentar e manuseio pré-abate afetam a qualidade do peixe destinado à mesa. Revista Panorama da Aqüicultura, p.39-49, 1999.

KUBITZA, F. Tilápia: tecnologia e planejamento na produção comercial. São Paulo: Degaspari, 2000. 289p.

KUBITZA, F. Qualidade da água no cultivo de peixes e camarões. Jundiaí: Degaspari. 2003. 229p.

LACERDA, B.F.C. Contribuição para a avaliação de parâmetros de qualidade de água do sistema Guarapiranga. São Paulo, 2003. 104p. Dissertação (Mestrado) - Escola Politécnica, Universidade de São Paulo. 
LEMBO,

A.

Editora

Saraiva.

www.editorasaraiva.com.br/eddid/ciencias/biblioteca/artigos/esgotp. (17 abr. 2004)

LIMA, J.S.G. Ocorrência de “off flavor” e processo de depuração em peixes de água doce cultivados. Jaboticabal, 2001. 54p. Dissertação (Mestrado) - Centro de Aqüicultura, Universidade Estadual Paulista “Júlio de Mesquita Filho”.

LOVELL, R.T.;. Processing farm-raised catfish. Rome: s.ed, 1974, p.37-42. (Southern Cooperative Series)

LOVELL, R.T. Flavor problems in fish culture. Rome: FAO, 1976. p.9. (FAO: Technical Conference on Aquaculture)

LOVSHIN, LL. Tilapia farming: a growing worldwide aquaculture industry. In: CYRINO, J.E.P.; KUBITZA, F. SIMPÓSIO SOBRE MANEJO E NUTRIÇÃO DE PEIXES. Piracicaba, 1997.Anais. Campinas: CBNA, 1997. p.137-164.

LOVSHIN, L.L.; CYRINO, P.E.P. Status of commercial fresh water fish culture in Brazil. In: SIMPÓSIO SOBRE MANEJO E NUTRIÇÃO DE PEIXES, 2., Piracicaba, 1998. Anais. Campinas: CBNA, 1998. p. 1-20.

LOZANO, J.E. El arte de evaluar los sabores. La Alimentación Latinoamericana, v.33, n.229, p.42-43, 1999.

MACHADO, Z.L. Tecnologia de recursos pesqueiros. Recife: Minter e Sudene, 1984. 227p.

MACKERETH, F.J.H.; HERON, J.; TALLING, J.F. Water analysis: some revised method for limnologists. Kendall: Titus Wilson, 1978. 117p. 
MARGALEF, R. Limnologia. Barcelona: Omega, 1983. 159p.

MARTIN, R.E. Seafood products- technology and research in the U.S. Food Technology, v.42, n.3, p. 58-62, 1988.

MATSUZAKI, M. A comunidade fitoplanctônica de um pesqueiro na cidade de São Paulo: aspectos ecológicos e sanitários, São Paulo, SP; 2002. 88p. Dissertação (Mestrado) - Faculdade de Saúde Pública, Universidade de São Paulo.

McGUIRE, M.J.; JONES, R.M.; MEANS, E.G.; IZAGUIRRE, G.; PRESTON, A.E. Controlling of chlorine dioxide. Journal of American Water Works Association. v.1, n.1, p. 60-65, 1984.

MEANS, E.G.; McGUIRE, M.J. An early warning system for taste and odor control. Journal American Water Works Association, v.1, n.1, p.77-83, 1986.

MELO FRANCO, B.D.G.; LANDGRAF, M. Microbiologia dos alimentos. São Paulo: Atheneu, 1996. 182p.

MILLER, D.; CONTE, E.D.; SHEN, C.Y.; PERSCHBACHER, P.W. Colorimetric approach to cyanobacterial off-flavor detection. Water Science Technology, v.40, n.6, p.165-169, 1999.

MOLLE, F.; CADIER, E. Manual do pequeno açude. Recife: SUDENE/Orstom/Tapi, 1992. 523p.

MORAIS, C. Princípios da defumação de pescado. Guarujá: ITAL, 1994. p.21-28. 
MORGA, A.A. Avaliação do índice de frescor da pescada foguete (Macrodon Ancylodon), conservada em gelo. Campinas, 1975. 80p. Dissertação (Mestrado)Faculdade de Engenharia de Alimentos e Agrícola, Universidade Estadual de Campinas.

MORKORE, T.; VALLET, J.L.; CARDINAL.; GOMEZ-GUILLEN, M.C.; MONTEIRO, P.; TORRISSEN, O.J.; NORTVEDT, R.; SIGURGISLADOTTIR, S.; THOASSEN, M.S. Fat content and fillet shape of Atlantic salmon: relevance for processing yileld and quality of raw and smoked products. Food Engineering and Physical Properties, v.66, n.9, p.1348-1354, 2001.

MORRIS, R.L.; DOUGHERTY, J.D.; RONALD, G.W. Chemical aspects of actinomycete metabolites as contributors of taste and odor. Journal American Water Works Association, v.1, n.1, p. 13280-1390, 1963.

MOURA, A.T.N. Estrutura e dinâmica da comunidade fitoplanctônica numa lagoa eutrófica, São Paulo, SP, Brasil a curtos intervalos de tempo: comparação entre épocas de chuva e seca. Rio Claro, 1996. 78p. Dissertação (Mestrado) - Instituto de Biociências do “Campus” de Rio Claro, Universidade Estadual Paulista “Júlio de Mesquita Filho".

NETTO, F.M. Modificações químicas, bioquímicas e sensoriais do híbrido de tilápia estocado em gelo. Campinas, 1984. 79p. Dissertação (Mestrado) - Faculdade de Engenharia de Alimentos, Universidade Estadual de Campinas.

OETTERER, M. Industrialização do pescado cultivado. Guaíba: Agropecuária, 2002. 200p.

OGAWA, M.; MAIA, E.L. Manual de pesca: ciência e tecnologia do pescado. São Paulo: Varela, 1999. v.1. 453p. 
PÁDUA, H.B. Sabores e odores em sistemas aquáticos. São Paulo: s.ed, 1994. p.8486.

PELCZAR, M.J.; CHAN, E.C.S.; KRIEG, N.R. 2.ed. Microbiologia: conceitos e aplicações. São Paulo: Makron Books, 1996. cap.29, p.327-370: Microbiologia das águas naturais potáveis e dos esgotos.

PEREIRA, G.P.C; PEQUITO,M.M.A.; COSTA, P.C.R.C. O impacto do incremento das cianobactérias como indicador de toxidade, 1999. www.fmv.utl.pt/democ/sht/sem9899/G005.htm. (18 set. 2003)

PERSSON, P.E. Uptake and release of environmentally occuring odorous compounds by fish. Water Research, v.18, n.10, p.1263-1271, 1984.

PERSSON, P.E. $19^{\text {th }}$ Century and early $20^{\text {th }}$ century studies on aquatic off flavors $-A$ historical review. Water Research Technology. v.31, n.11, p.9-13, 1995.

PETERSON, H.G., HRUDEY, S.E., CANTIN, I.A., PERLEY, T.R., KENEFICK, S.L. Physiological toxicity, cell emmbrane damage and the release of dissolved oganic carbon and Geosmina by Aphanizomenon flos-aquae after exposure to water treatment chemicals. Water Research, v.1, n.1, p.1515-1523. 1995.

PILLAY, T.V.R. Aquaculture and fishery products development. Fishery products, v.3, n.9, p.250-253, 1974.

PLOEG, M.V.D.; BODY, C.E. Geosmin production by cyanobacteria (blue-green algae) in fish ponds at Auburn, Alabama. Journal of the World Aquaculture Society, v.22, p.207-216, 1992. 
PORTUGAL FILHO, G. GPCA-Meio Ambiente. www.gpca.com.br/gil/art. (17 abr. 2004)

REINECCIUS, G.A. Off flavors in meat and fish-a review. Journal of Food Science, v.44, p.12-24, 1979.

REPAVICH, W.M.; SONZOGNI, W.C.; STRANDRIDGE, J.H.; WEDEPOHL, R.E.; MEISNER, L.F. Cyanobacteria in Wisconsin waters; acute and chronic toxicity. Water Research, v.8, n.6, p.225-231, 1990.

ROMANO, A.H.; SAFFERMAN, R.S. Studies on actinomycetes and their odors. Journal American Water Works Association, v.7, n.1, p. 169-176, 1963.

SANCHEZ, L. Pescado: matéria-prima e processamento. Campinas: Fundação Cargill, 1989. 61p.

SANT’ANNA, C.L.; AZEVEDO, M.T.P.; SORMUS, L. Fitoplâncton do lago das Garças, Parque Estadual das Fontes do Ipiranga, São Paulo, Brasil; Estudo Taxonômico e Aspectos ecológicos. Hoehnea, v. 16, n.1, p.89-131, 1989.

SANT’ANNA, C.L.; AZEVEDO, M.T.P.; SORMUS, L, TUCCI, A. Variação Sazonal do Fitoplâncton do Lago das Garças, São Paulo. Hoehnea, v. 4, n.1, p. 67-86, 1997.

SANT’ANNA, C.L.; XAVIER, M.B.; SORMUS, L. Estudo qualitativo do fitoplâncton da represa de Serraria, Estado de São Paulo, Brasil. Revista Brasileira de Biologia, v.48, n.1, p.83-102, 1988

SAS INSTITUTE. SAS user's guide: statistics (software). Version 8.0. Cary: Sas Institute, 1999. 
SCHRADER, D.; REGT, M.Q.; TIDWELL, P.D.; TUCKER, C.S.; DUKE, S.O. Compounds with selective toxicity towards the off flavor metabolite-producing cyanobacterium Oscillatoria chalybea. Aquaculture, n.163, p.85-99, 1998.

SIKORSKI, Z.E.; KOLAKOWSKA, A.; BURT, J.R. Cambios bioquimicos y microbianos subsiguientes a la captura. In: SIKORSKI, Z.E. (Ed.). Tecnología de los productos del mar: recursos, composition y conservation. Zaragoza: Acribia, 1994. cap.4, p.73-101.

SILVA, N.; JUNQUEIRA, V.C.A.; SILVEIRA, N.F.A. Manual de métodos de análises microbiológicas de alimentos. São Paulo: Varela, 1997. 295p.

SILVEY， J.K.G.; RUSSEL， J.C.; REDDEN, D.R., McCORMICK, W.C. Actinomycetes and common tastes and odors. Journal American Water Works Association, v.5, n.2, p.1018-1026, 1950.

SOCCOL, M.C.H.; BIATO, D.; OETTERER, M. A acidificação como complemento para extensão da vida útil de tilápias (Oreochromis niloticus) minimamente processadas (compact disc). In: CONGRESSO BRASILEIRO DE CIÊNCIA E TECNOLOGIA DE ALimenTOS, 18., Porto Alegre, 2002. Anais. Porto Alegre: SBCTA, 2002. p.224-228.

SOUTHCOTT, B.A.; RAZELL, W.E. Clostridium botulinum control in cold-smoked salmon: a review. Journal Fisheries Research Board of Canada, v.30, n.5, p.631641.

SOUZA, A.P. Informação Pessoal, Engenheiro Sanitarista, Consultor de Saneamento Básico, 1996. www.redeambiente.org.br/dicionario. (17 abr. 2004) 
SOUZA, M.L.R. Processamento do filé da tilápia do nilo (Oreochromis niloticus): Aspectos tecnológicos, composição centesimal, rendimento, vida útil do filé defumado e testes de resistência da pele curtida. Jaboticabal, 2003. 166p. Tese (Doutorado) - Centro de Aqüicultura, Universidade Estadual Paulista "Julio de Mesquita Filho".

SZENTTAMÁSY, E. R.; BARBOSA, S. M. V. B.; OETTERER, M.; MORENO, I. A. M. Tecnologia do pescado de água doce: aproveitamento do pacú (Piaractus mesopotamicus) Scientia Agrícola, v.50, n.2, p. 303-310, 1993.

TABACHEK, J.L.; YURKOWSKI, M. Isolation and identification of nlue-green algas producing muddy odor metabolites, geosmin, and 2-methylisoborned, in saline lakes in Manitoba. Journal of Fisheries Research Board of Canada, v.33, p.25-35, 1976.

THAYSEN, A.C. The origin of an earthy or muddy taint in the fish I the nature and isolation of the taint. Annual Applying Biology, v.23, p.99-104, 1936.

THAYSEN, A.C.; PENTELOW, F.T.K. The origin of an earthy or muddy taint in the fish II the effect of fish the of the taint produced and odoriferous species of Actinomyces. Annual Applying Biology, v.23, p.105-109, 1936.

TORLONI, C.E.C; BRAGA, J.T.;REIS, M.A.G.;ANDRADE, M. O. Eliminação do sabor e do odor desagradáveis em tilápias do nilo (Sarotherodon niloticus) pelo processo de depuração. Ciência e Cultura, v.34, n.5 p.657- 663, 1983.

TUCKER, C.S.; PLOEG, M.V.D. Managing off flavor problems in pond-raised catfish. Southtern Regional Aquaculture Center, n.192. 1999. 7p 
TUCKER, C.S.; MARTIN, J.F. Environmental related off-flavors in fish. Water quality in aquaculture. In: TOMASO, J.R.; BRUNE, D (Ed.). World aquaculture books. London: s.ed., 1991. cap.2, p.133-179.

UTERMÕHL, H. Zur Vervollkommung der Quantitativen Phytoplankton Methodik. Mitting International Vereina Liminology, v. 9, p. 1-38, 1958.

VANDERZANT, C.; SPLITTSTOESSER, D. F. Compendium of methods for the microbiological examination of foods. 3.ed. Washington: American Public Health Association, 1992. cap. 25, p.1219.

VANNUCCINI, S. El enfoque Del nuevo mercado de tilapia; en el mundo Occidental. Panorama Acuícola, v.4, n.3, p.22-25, 1999.

VAZ, J.O.; PARREIRA, W.B. A tilápia. São Paulo: Departamento de Produção Animal, s.d. 12p.

WILDE, J.W.; KAMSTRA, A. Producción pesquera. In: RUTER, A. El pescado y los productos derivados de la pesca: composición, propriedades nutritivas y estabilidad. Zaragoza: Acribia, 1999, cap. 1, p.1-31.

XAVIER, M.B. Represa Billings-São Paulo II. Variação sazonal do fitoplâncton. Boletim do Instituto de Pesca, v. 8, p. 47-64, 1981

XAVIER, M.B. Estudo comparativo da flora de euglenaceae pigmentadas (Euglenophyceae) de lagos do parque estadual das fontes do Ipiranga, São Paulo. São Paulo, 1985. 69p. Tese (Doutorado) - Faculdade de Saúde Pública, Universidade de São Paulo. 
YAMPRAYOON, J.; NOOMHORM, A. Effects of preservation methods on geosmin content and off flavor in Nile tilápia (Oreochromis niloticus). Journal of Aquatic Food Product Technology, v.9, n.4, p.95-107, 2000.

ZEITOUNI, R. Educação ambiental. www.bio2000.hpg.ig.com.br/limnologia. (17 abr. 2004) 